\title{
Buku Ajar Mata Kuliah \\ Teknik Optimasi
}

\author{
Oleh
}

Novia Ariyanti; Nuril Lutvi Azizah

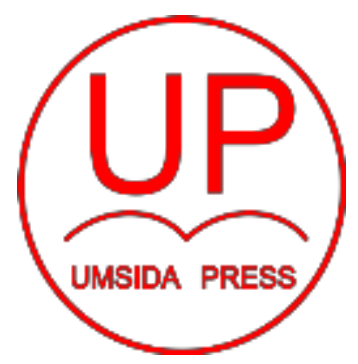

Diterbitkan oleh

UMSIDA PRESS

Tahun 2019 


\section{Buku Ajar \\ Teknik Optimasi}

\section{Penulis :}

Novia Ariyanti; Nuril Lutvi Azizah.

\section{ISBN :}

978-602-5914-82-9

\section{Editor :}

Septi Budi Sartika, M.Pd

M. Tanzil Multazam, S.H., M.Kn.

\section{Copy Editor :}

Fika Megawati, S.Pd., M.Pd.

Design Sampul dan Tata Letak :

Mochamad Nashrullah, S.Pd

\section{Penerbit :}

UMSIDA Press

\section{Redaksi :}

Universitas Muhammadiyah Sidoarjo

Jl. Mojopahit No 666B

Sidoarjo, Jawa Timur

Cetakan pertama, Agustus 2019 
(C) Hak cipta dilindungi undang-undang Dilarang memperbanyak karya tulis ini dengan suatu apapun tanpa ijin tertulis dari penerbit. 


\section{KATA \\ PENGANTAR}

Perkembangan teknologi dan bidang ilmu yang pesat saat ini menuntut adanya kemampuan manusia dalam mempertimbangkan segala kemungkinan sebelum mengambil keputusan dan tindakan. Keputusan yang diambil dalam bidang usaha yang mengandung resiko besar tentunya perlu didukung oleh perhitungan-perhitungan yang matang, agar resiko kerugian dapat diminimalisir bahkan dihindari. Oleh karena itu, diperlukan teknik-teknik atau metodemetode untuk kuantitatif yang lebih lengkap untuk memecahkannya. Teknik-teknik atau metode-metode tersebut terdapat dalam mata kuliah Teknik Optimasi yang pada prinsipnya berisi berbagai teknik kuantitatif yang banyak dipakai dalam pengambilan keputusan. Dengan kata lain, diharapkan pengetahuan yang diperoleh dari mata kuliah ini dapat dipakai sebagai pegangan yang pasti atau dasar yang kuat bagi keputusan-keputusan yang diambil.

Sayangnya buku ajar untuk mata kuliah ini belum tersedia. Melihat kebutuhan yang mendesak tersebut, penulis mencoba untuk menyusun sebuah buku yang kami yakin dapat memberikan pengetahuan pada mahasiswa.

Akhirnya, penulis mengucapkan terima kasih atas segala bantuan yang telah diberikan oleh berbagai pihak, terutama pada Universitas Muhammdiyah Sidoarjo sehingga dapt terlaksananya penulisan buku ini. Penulis menyadari bahwa buku ini masih jauh dari sempurna. Oleh karena itu, segala kritik, tanggapan maupun saran yang bersifat membangun dari segenap pembaca sangat diharapkan, demi perbaikan di masa-masa mendatang.

Sidoarjo, Agustus 2018

Novia Ariyanti, S.Si.,M.Pd

Nuril Lutvi Azizah, S.Si.,

M.Pd. 


\section{DAFTAR ISI}

Kata Pengantar $\quad$ i

Daftar Isi ii

BAB 1 Pendahuluan

Perkembangan Teknik Optimasi 1

Arti Teknik Optimasi 2

BAB 2 Program Linear

Pendahuluan

Metode Grafik Masalah Maksimisasi

Latihan soal

BAB 3 Metode Simplex dalam Program Linear

Pendahuluan

Langkah-langkah Metode Simplex

Penyimpangan-penyimpangan dari bentuk standar

Latihan soal

BAB 4 Dualitas dalam Program Linear dan Analisa

Sensitivitas

Teori Dualitas

Analisa Sensivitas

Latihan Soal

BAB 5 Metode Transportasi

Pendahuluan

Metode Stepping Stone

Metode Modi

Metode Vogel's Approximation Method (VAM)

Latihan Soal

BAB 6 Masalah Penugasan

Perumusan Masalah 
Jumlah Pekerjaan tidak sama dengan jumlah karyawan

Masalah Maksimisasi

Masalah-masalah penugasan tambahan

Latihan Soal

BAB 7 Analisa Network

Pendahuluan

Metode Algoritma

Metode Matriks

Metode Programming

Memperpendek waktu selesainya proyek

Bentuk-bentuk lain dari fungsi Biaya Perpendekan

Latihan Soal

BAB 8 Teori Antrian

Pendahuluan

Konsep-konsep Dasar Teori Antrian

Sistim dan Struktur Antrian

Model-model Antrian

Model-model dan Aplikasinya

Latihan Soal

Daftar Pustaka 


\section{A. Perkembangan Teknik Optimasi}

Setiap orang pasti ingin memperoleh yang terbaik dalam hidupnya, memaksimalkan atau mengoptimalkan apa yang dia miliki untuk memperoleh sesuatu yang lebih baik. Hal tersebut juga terjadi dalam dunia industri dan pemprograman, dimana setiap keputusan yang dibuat diharapkan bisa memecahkan sebuah permasalahan yang ada dengan seoptimal mungkin. Optimalisasi matematis berawal pada riset operasi yang dikembangkan dalam perang dunia II. Sebagian besar masalah optimasi dunia nyata melibatkan beberapa tujuan yang saling bertentangan yang harus dipertimbangkan secara bersamaan, disebut masalah optimasi vektor. Proses solusi untuk masalah optimisasi vektor ada tiga, berdasarkan metode pengambilan keputusan, metode untuk mengatasi kendala nonlinier dan algoritma optimisasi untuk meminimalkan fungsi tujuan.

Pada bidang pemprograman, dimana setiap algoritma harus mampu menyelesaikan solusi optimal dari suatu permasalahan. Dalam perkembangannya banyak sekali algoritma yang muncul Teknik Optimasi 
maupun algoritma hasil pengembangan dari algoritma yang sudah ada. Dalam perkembangannya, penilaian performansi sebuah algoritma sangat diperhitungkan. Biasanya penilaian performansi tersebut terhadap nilai waktu yang dibutuhkan algoritma untuk berjalan (running) dan juga terhadap presisi atau keakuratan hasil dari sebuah algoritma.

\section{B. Arti Teknik Optimasi}

Teknik optimasi, adalah menentukan di mana dan kapan optimasi harus diterapkan. Menurut definisi, optimasi adalah "proses" produksi lebih efisien (lebih kecil dan / atau lebih cepat) program melalui seleksi dan desain struktur data, algoritma, dan urutan instruksi dan lain-lainnya. Banyak Faktor yang berkaitan dengan optimasi, seperti optimasi komputer, optimasi Web dan lain-lainnya, sehingga optimasi memang diperlukan untuk hal apapun.

Optimasi itu artinya membuat sesuatu sebagus mungkin.atau paling maksimal.Persoalan optimasi adalah persoalan yang sangat penting untuk diterapkan untuk segala sistem maupun organisasi. Dengan optimasi pada sebuah sistem kita akan bisa berhemat dalam segala hal antara lain energi, keuangan, sumber daya alam, kerja dan lain-lain, tanpa mengurangi fungsi sistem tersebut. Peranan kalimat 
optimasi juga banyak diterapkan pada situs-situs yang berkecipung dalam bidang SEO maupun teknologi lainnya.

Teknik Optimasi 


\section{A. Pendahuluan}

Salah satu pendekatan yang dapat dilakukan untuk menyelesaikan masalah manajemen sains adalah pemrograman linier. Pemrograman linier merupakan kelompok teknik analisis kuantitatif yang mengandalkan model matematika atau model simbolik sebagai wadahnya. Artinya setiap masalah yang kita hadapi dalam suatu sistem permasalahan tertentu perlu dirumuskan dulu dalam simbol-simbol matematika tertentu, jika kita inginkan bantuan pemrograman linier sebagai alat analisisnya.

Secara umum program linier merupakan salah satu teknik menyelesaikan riset operasi, dalam hal ini adalah khusus menyelesaikan masalah-masalah optimasi (memaksimalkan atau memininumkan) tetapi hanya terbatas pada masalah-masalah yang dapat diubah menjadi fungsi linear. Secara khusus, persoalan program linear merupakan suatu persoalan untuk menentukan besarnya masing-masing nilai variabel sehingga nilai fungsi tujuan atau objektif yang linear menjadi optimum (memaksimalkan atau meminimumkan) dengan memperhatikan adanya kendala yang ada, yaitu kendala yang harus dinyatakan dalam bentuk ketidaksamaan yang linear. Banyak 
sekali keputusan utama dihadapi oleh seorang manajer perusahaan untuk mencapai tujuan perusahaan dengan batasan situasi lingkungan operasi. Pembatasan tersebut meliputi sumberdaya misalnya waktu, tenaga kerja, energi, bahan baku, atau uang. Secara umum, tujuan umum perusahaan yang paling sering terjadi adalah sedapat mungkin memaksimalkan laba. Tujuan dari unit organisasi lain yang merupakan bagian dari suatu organisasi biasanya meminimalkan biaya. Saat manajer berusaha untuk menyelesaikan masalah dengan mencari tujuan yang dibatasi oleh batasan tertentu, teknik sains manajemen berupa program linear sering digunakan untuk permasalahan ini.

\section{B. Metode Grafik Masalah Maksimisasi}

Metode grafik adalah salah satu metode yang digunakan untuk menyelesaikan permasalahan program linier, dan merupakan salah satu metode yang sering digunakan, karena metode ini cukup mudah dan tidak memakan terlalu banyak waktu. Akan tetapi, penggunaan metode grafik ini terbatas dikarenakan metode ini hanya dapat digunakan untuk menyelesaikan permasalahan program linier dengan dua variable. Karena untuk menyelesaikan permasalahan program linier dengan tiga variable diperlukan grafik dalam bentuk tiga dimensi, dan akan cukup rumit. Sedangkan untuk permasalahan 
program linier dengan empat atau lebih variable tidak dapat dibuat grafiknya.

Dalam metode grafik ini, penentuan titik optimum memiliki dua cara alternatif, yaitu dengan uji titik pojok dan dengan garis selidik. Kedua cara tersebut akan dibahas dalam materi.

\section{a. Langkah-langkah penyelesaian}

1. Apabila soal yang berbentuk soal cerita, tentukanlah fungsi tujuan dan kendalanya.

2. Gambarkanlah setiap fungsi kendala dengan mencari titik potong fungsi tersebut dengan sumbu $X$ dan sumbu $Y$ ( $X_{1}$ merupakan titik pada sumbu $X$ dan $X_{2}$ merupakan titik sumbu $Y$ ).

3. Untuk menentukan daerah penyelesaian, dapat menggunakan salah satu cara berikut:

a. Dengan pengujian tanda

1) Ambil sembarang titik yang ada di luar garis (untuk lebih memudahkan, sebaiknya ambil titik $(0,0))$.

2) Masukkan titik tersebut ke dalam pertidaksamaan.

3) Jika titik tersebut memenuhi pertidaksaman, maka daerah penyelesaian adalah daerah di mana titik tersebut berada, dan sebaliknya.

b. Dengan cara alternatif

1) Lihat tanda di depan variabel $x_{2}(+$ atau -$)$. 
2) Lihat tanda pertidaksama- an, tanda " $\leq$ " berarti " - " dan tanda " $\geq$ " berarti " + ".

3) Lakukan perkalian antara kedua tanda tersebut. Bila hasil perkalian tanda adalah positif, maka daerah penyelesaian berada di atas garis, dan sebaliknya.

4. Carilah titik potong setiap fungsi kendala yang ada dengan menggunakan metode eliminasi atau substitusi.

5. Grafik telah selesai dan siap di cari titik optimasi.

b. Adapun contoh cara menyelesaikan metode grafik sebagai berikut:

1. Seorang produsen memiliki 2 macam bahan, yaitu bahan I sebanyak 8 ton dan bahan II sebanyak 5 ton berkeinginan untuk memproduksi 2 macam produk A dan B. Untuk 1 unit produk A membutuhkan 2 unit bahan I dan 1 unit bahan II sedangkan untuk 1 unit produk B membutuhkan 3 unit bahan I Dan 2 unit bahan II. Harga pasar untuk Produk $A$ sebesar Rp. 15.000/unit dan Rp.10.000/unit. Berapakah produsen tersebut harus memproduksi produk $A$ dan $B$ untuk memproduksi hasil penjualan yang maksimum? 
Penyelesaian:

\begin{tabular}{|c|c|c|c|}
\hline & Produk A & Produk B & $\begin{array}{c}\text { Penyediaan } \\
\text { Barang }\end{array}$ \\
\hline Bahan I & 2 & 3 & 8 ton \\
\hline Bahan II & 1 & 2 & 5 ton \\
\hline Harga & 15.000 & 10.000 & $?$ \\
\hline
\end{tabular}

Misal :

Produk $A=x$

Produk $B=y$

- Fungsi Tujuan :

$Z \max =15.000 x+10.000 y$

- Fungsi Kendala :

$$
\begin{aligned}
& 2 x+3 y \leq 8 \\
& x+2 y \leq 5
\end{aligned}
$$

- Titik Potong :

$$
\begin{aligned}
& 2 x+3 y=8 \\
& x=4, y=\quad=2 \\
& x+2 y=5 \\
& x=5, y=\quad \frac{5}{3} \frac{5}{3} \quad=1
\end{aligned}
$$


- Grafik :

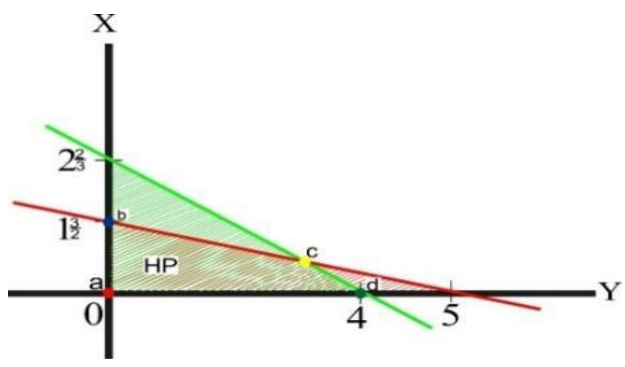

a. $(0,0)$

b. $\left(0,1 \frac{3}{2} \frac{3}{2}\right)=15.000 x+10.000 y$

$$
\begin{aligned}
& =15.000(0)+10.000\left(1 \frac{3}{2} \frac{3}{2}\right) \\
& =0+25.000=25.000
\end{aligned}
$$

c. Garis 1 dan 2

$$
\begin{array}{r}
2 x+3 y=8 \quad x 1 \quad 2 x+3 y=8 \\
x+2 y=5 \quad x 2 \quad 2 x+4 y=10 \\
-y=-2 \\
y=2
\end{array}
$$

Subsitusikan $\mathrm{y}=2$ ke salah satu persamaan

$$
\begin{aligned}
& x+2 y=5 \\
& x+2(2)=5 \\
& x+4=5 \\
& \quad x=5-4
\end{aligned}
$$

Teknik Optimasi 


$$
x=1
$$

- $(1,2)=15.000 x+10.000 y$

$$
=15.000(1)+10.000(2)
$$$$
=15.000+20.000
$$$$
=35.000
$$

d. $(4,0)=15.000 x+10.000 y$

$$
\begin{aligned}
& =15.000(4)+10.000(0) \\
& =60.000
\end{aligned}
$$

Jadi, penjualan maksimum menghasilkan sebesar Rp.60.000 dengan Produk A 4 buah dan Produk B 0 buah.

2. Perusahaan "Sido Makmur" mempunyai kendala keterbatasan jam kerja. Untuk pembuatan 1 unit meja dia memerlukan 4 jam kerja. Untuk pembuatan 1 unit kursi dia membutuhkan 3 jam kerja. Untuk pengecatan 1 unit meja dibutuhkan 2 jam kerja, dan untuk pengecatan 1 unit kursi dibuthkan 1 jam kerja. Jumlah jam kerja yang tersedia untuk pembuatan meja dan kursi adalah 240 jam per minggu sedang jumlah jam kerja untuk pengecatan adalah 100 jam per minggu. Berapa jumlah meja dan kursi yang sebaiknya diproduksi agar keuntungan perusahaan maksimum? 
Penyelesaian:

\begin{tabular}{|c|c|c|c|}
\hline & \multicolumn{2}{|c|}{$\begin{array}{l}\text { Jam kerja untuk } \\
\text { membuat } 1 \text { produk }\end{array}$} & \multirow{2}{*}{$\begin{array}{l}\text { Total } \\
\text { waktu } \\
\text { tersedia }\end{array}$} \\
\hline & Meja & Kursi & \\
\hline Pembuatan & 4 & 3 & 240 \\
\hline Pengecetan & 2 & 1 & 100 \\
\hline Keuntungan & 5.000 & 3.000 & $?$ \\
\hline
\end{tabular}

- Misal :

Meja $=x$

Kursi $=\mathrm{y}$

- Fungsi Tujuan :

$Z \max =5.000 \mathrm{x}+3.000 \mathrm{y}$

- Fungsi Kendala :

$$
\begin{aligned}
& 4 x+3 y \leq 240 \\
& 2 x+y \leq 100
\end{aligned}
$$

- Titik Potong :

$$
\begin{array}{lc}
4 x+3 y=240 & \\
4 x=240 & 3 y=240 \\
\frac{240}{4} \frac{240}{4} & y= \\
x= & y=80
\end{array}
$$

Teknik Optimasi 


$$
\begin{aligned}
& 2 x+y=100 \quad y=100 \\
& 2 x=100 \\
& \quad \frac{100}{2} \frac{100}{2} \\
& x= \\
& x=50
\end{aligned}
$$

- Grafik :

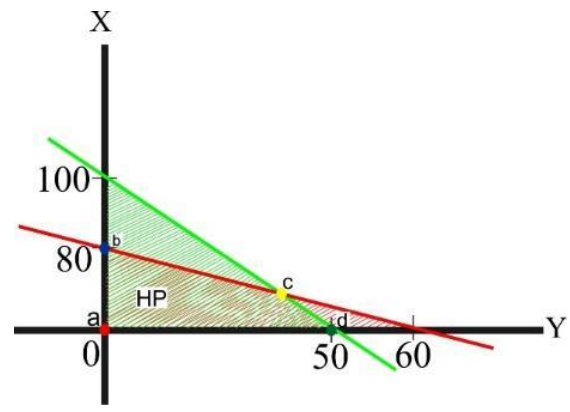

a. $(0,0)$

b. $(0,80)=5.000 x+3.000 y$

$=5.000(0)+3.000(80)$

$$
=0+160.000=160.000
$$

c. Garis 1 dan 2

$$
\begin{aligned}
4 x+3 y=240 \quad x 1 \quad 4 x+3 y & =240 \\
2 x+y=100 \quad x 3 \quad 6 x+3 y & =300 \\
-2 x & =-60 \\
x & =30
\end{aligned}
$$

Teknik Optimasi 


$$
\begin{aligned}
& 2 x+y=100 \\
& 2(30)+y=100 \\
& 60+y=100 \\
& y=40 \\
& \quad \quad 5000 x+3000 y \\
& =5000(30)+3000(40) \\
& \quad=150.000+120.000 \\
& \text { d. } \quad(50,0)=5.000 x+3.000 y \\
& =5.000(50)+3.000(0) \\
& =250.000
\end{aligned}
$$

Jadi, keuntungan perusahaan maksimum menghasilkan sebesar Rp.270.000 dengan 30 unit meja dan dengan 40 unit kursi.

\section{Metode Grafik Masalah Minimisasi}

Permasalahan minimisasi dapat juga diselesaikan secara grafik. Langkah-langkah penyelesaian permasalahan sama dengan penyelesaian permasalahan untuk fungsi tujuan maksimisasi yaitu: formulasi permasalahan, menentukan area layak, serta menentukan solusi optimal.

Dalam menentukan solusi optimal, seperti halnya pada permasalahan maksimisasi, dapat digunakan pendekatan garis profit 
atau titik sudut. Untuk lebih memahami penyelesaian permasalahan minimisasi berikut dibahas dalam contoh soal berikut.

Contoh:

1. Perusahaan makanan ROYAL merencanakan untuk membuat dua jenis makanan yaitu Royal Bee dan Royal Jelly. Kedua jenis makanan tersebut mengandung vitamin dan protein. Royal Bee paling sedikit diproduksi 2 unit dan Royal Jelly paling sedikit diproduksi 1 unit. Tabel berikut menunjukkan jumlah vitamin dan protein dalam setiap jenis makanan:

\begin{tabular}{|l|c|c|c|}
\hline \multicolumn{1}{|c|}{ Jenis makanan } & Vitamin (unit) & Protein (unit) & $\begin{array}{c}\text { Biaya per unit } \\
\text { (ribu rupiah) }\end{array}$ \\
\hline Royal Bee & 2 & 2 & 100 \\
\hline Royal Jelly & 1 & 3 & 80 \\
\hline minimum kebutuhan & 8 & 12 & \\
\hline
\end{tabular}

Bagaimana menentukan kombinasi kedua jenis makanan agar meminimumkan biaya produksi.

Penyelesaian:

Langkah - langkah:

1. Langkah Pertama (Menentukan Variabel)

$$
\begin{aligned}
& X_{1}=\text { Royal Bee } \\
& X_{2}=\text { Royal Jelly }
\end{aligned}
$$

2. Langkah Kedua (Menentukan Fungsi Tujuan)

$$
\mathrm{Zmin}=100 \mathrm{X}_{1}+80 \mathrm{X}_{2}
$$

3. Syarat Ikatan (Menentukan Fungsi Kendala) 


$$
\begin{aligned}
& 2 X_{1}+X_{2} \geq 8 \text { (vitamin) } \\
& 2 X_{1}+3 X_{2} \geq 12 \text { (protein) } \\
& X_{1} \geq 2
\end{aligned}
$$

* Lihat tabel atas

$$
X_{2} \geq 1
$$

4. Langkah Keempat (Membuat grafik)

$$
\begin{aligned}
& 2 X_{1}+X_{2}=8 \\
& X_{1}=0, X_{2}=8 \\
& X_{2}=0, X_{1}=4 \\
& 2 \mathrm{X}_{1}+3 \mathrm{X}_{2}=12 \quad * \text { Lihat grafik } 2 \\
& X_{1}=0, X_{2}=4 \\
& X_{2}=0, x_{1}=6 \\
& \mathrm{X}_{1}=2 \\
& X_{2}=1
\end{aligned}
$$

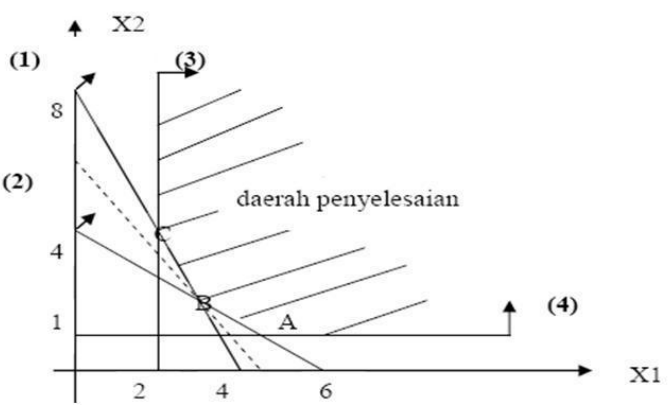

5. Langkah Kelima (Identifikasi Daerah Solusi yang Layak) 
Titik-titik yang layak memenuhi semua keterbatasan sumber daya tersebut berada di daerah bergaris pada Gambar grafik tersebut. Daerah yang layak ini dikelilingi oleh titik-titik A, B, C.

6. Langkah Keenam (Menentukan titik yang memberikan nilai obyektif optimal pada daerah solusi layak)

- Titik A yaitu titik potong antara $\mathbf{X}_{\mathbf{2}}=\mathbf{1}$ dengan garis $2 X_{1}+3 X_{2}=12$, untuk mencari nilai $X_{1}$ dengan menggunakan metode Substitusi sebagai berikut :

$$
\begin{aligned}
2 X_{1}+3 X_{2} & =12 \\
2 X_{1}+3(1) & =12 \\
2 X_{1} & =9 \\
X_{1} & =4.5
\end{aligned}
$$

Titik $A=(4.5,1)$

- Titik B yaitu titik potong antara garis $2 X_{1}+X_{2}=8$ dan garis $2 X_{1}+3 X_{2}=12$, Adapun cara menghitung titik $B$ dengan menggunakan metode Eliminasi dan Substitusi sebagai berikut:

$$
\begin{aligned}
2 X_{1}+X_{2} & =8 \ldots \ldots . . i) \\
2 X_{1}+3 X_{2} & =12 \ldots \ldots . \\
\hline-2 X_{2} & =-4 \\
X_{2} & =2
\end{aligned}
$$

Subsitusikan $\mathrm{X}_{2}$ ke kendala (1)

Teknik Optimasi 


$$
\begin{aligned}
2 X_{1}+X_{2} & =8 \\
2 X_{1}+2 & =8 \\
2 X_{1} & =6 \\
X_{1} & =3
\end{aligned}
$$

Titik $B=(3,2)$

- Titik $C$ yaitu titik potong antara $X_{1}=2$ dengan garis $2 X_{1}+X_{2}=$ 8, untuk mencari nilai $X_{1}$ dengan menggunakan metode Substitusi sebagai berikut :

$$
\begin{aligned}
2 X_{1}+X_{2} & =8 \\
2(2)+X_{2} & =8 \\
X_{2} & =4
\end{aligned}
$$

TITIK C $=(2,4)$

Penyelesaian dari soal diatas adalah menghitung nilai fungsi sasaran

$\left(Z \min =100 \mathrm{X}_{1}+80 \mathrm{X}_{2}\right)$, sehingga:

- Titik A $(4.5,1)$ :

$$
\begin{aligned}
Z \min & =100 X_{1}+80 X_{2} \\
& =100 \cdot 4,5+80 \cdot 1 \\
& =450+80=530
\end{aligned}
$$

- Titik B $(3,2)$ :

$$
\begin{aligned}
Z \min & =100 X_{1}+80 X_{2} \\
& =100.3+80.2
\end{aligned}
$$

Teknik Optimasi 


$$
=300+160=460
$$

- Titik C $(2,4)$ :

$$
\begin{aligned}
Z \min & =100 X_{1}+80 X_{2} \\
& =100.2+80.4 \\
& =200+320=\mathbf{5 2 0}
\end{aligned}
$$

7. Langkah Ketujuh (Mengartikan Solusi yang diperoleh)

Fungsi Tujuan adalah mencari nilai minimumnya sehingga nilai yang sesuai adalah :

Terletak pada titik B $(\mathbf{3}, \mathbf{2})$

Dengan nilai fungsi tujuannya Rp. $\mathbf{4 6 0 . 0 0 0}$

Sehingga untuk meminimumkan biaya produksi maka Perusahaan Makanan Royal memproduksi:

Royal Bee sebanyak 3 unit dan Royal Jelly sebanyak 2 unit

Dengan biaya sebesar $R p .460 .000$

2. Jihan ingin merencanakan membuat dua jenis makanan yaitu jenis makanan A dan jenis makanan B. Dia ingin mengetahui berapa banyak kedua jenis bahan makanan tersebut harus dibeli, karena dia ingin keluarganya mendapat makanan yang bergizi. Dia pernah membaca dalam majalah "NIRMALA" bahwa satu orang kebutuhan minimum perharinya adalah 12 unit protein dan 9 unit karbohidrat. Sedangkan kandungan unsur-unsur itu dalam jenis makanan A dari jenis makanan B dapat dilihat pada tabel berikut ini:

Teknik Optimasi 


\begin{tabular}{|c|c|c|}
\hline Kandungan & $\begin{array}{c}\text { Jenis Makanan } \\
\text { A } \\
\text { (unit) }\end{array}$ & $\begin{array}{c}\text { Jenis Makanan } \\
\text { B } \\
\text { (unit) }\end{array}$ \\
\hline Protein & 1 & 3 \\
\hline Karbohidrat & 2 & 1 \\
\hline
\end{tabular}

Di pasar dia melihat harga kedua jenis bahan makanan tersebut adalah satu jenis makanan A harganya Rp. 500,00 dan satu jenis makanan B harganya Rp. 300,00. Berapa biaya minimum yang harus dikeluarkan Jihan untuk membeli makanan yang bergizi?

Penyelesaian:

\begin{tabular}{|c|c|c|c|}
\hline Kandungan & $\begin{array}{c}\text { Jenis } \\
\text { Makanan } \\
\text { A } \\
\text { (unit) }\end{array}$ & $\begin{array}{c}\text { Jenis } \\
\text { Makanan } \\
\text { B } \\
\text { (unit) }\end{array}$ & $\begin{array}{l}\text { Jumlah } \\
\text { Minimum }\end{array}$ \\
\hline Protein & 1 & 3 & 12 \\
\hline Karbohidrat & 2 & 1 & 9 \\
\hline Harga & 500 & 300 & $?$ \\
\hline
\end{tabular}

- Misal :

Jenis Makanan $A=x$

Jenis Makanan $B=y$

Teknik Optimasi 
- Fungsi Tujuan :

$$
\mathrm{Zmin}=500 \mathrm{x}+300 \mathrm{y}
$$

- Fungsi Kendala :

$$
\begin{aligned}
& x+3 y \geq 12 \\
& 2 x+y \geq 9
\end{aligned}
$$

- Titik Potong :

$$
\begin{aligned}
& x+3 y=12 \\
& x=12, y=4 \\
& 2 x+y=9 \\
& \frac{9}{2} \frac{9}{2} \quad \frac{1}{2} \frac{1}{2} \\
& x=\quad=4, y=9
\end{aligned}
$$

- Grafik :

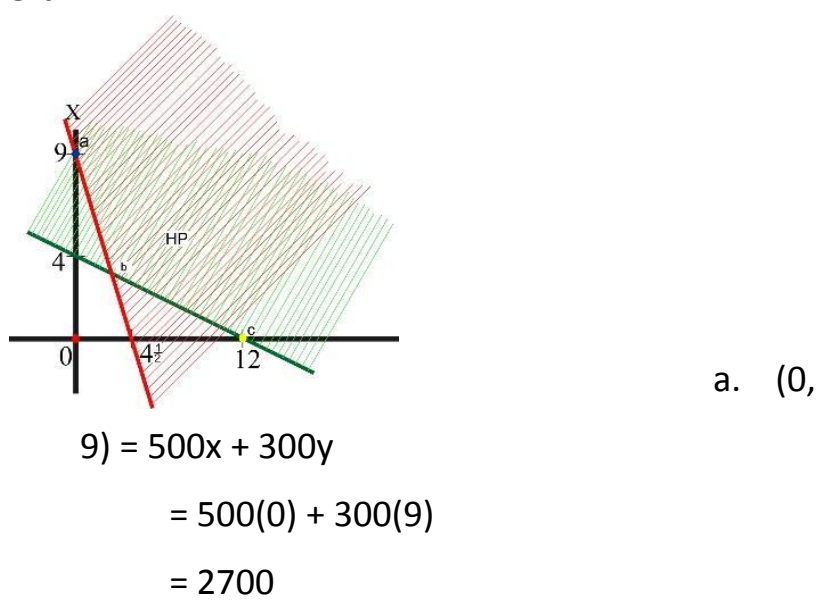

b. Garis 1 dan 2

$$
x+3 y=12 x 22 x+6 y=24
$$




$$
\begin{array}{rl}
2 x+y & =9 \quad x 12 x+y=9 \\
5 y=15 & y=3 \\
x+3 y & =12 \\
x+3(3)=12 & \\
x+9 & =12 \\
x & =12-9 \\
x & =3 \\
-500 x & +300 y \\
=500 & (3)+300(3) \\
=1500 & +900=2400 \\
\text { c. } \quad(12,0) & =500 x+300 y \\
& =500(12)+300(0) \\
& =6000
\end{array}
$$

Jadi, untuk pembelian dengan biaya minimum maka jenis makanan A dibeli 3 unit dan jenis makanan B dibeli 3 unit sehingga pengeluaran hanya Rp. 2.400,00.

\section{Latihan soal}

1. Seorang petani sedang membeli pupuk yang mengandung tiga nutrien $A, B$, dan $C$. Kebutuhan minimum adalah 160 satuan $A, 200$ satuan $B$, dan 80 satuan C. Ada dua pupuk terkenal yang tersedia di pasar. 
Tumbuh Cepat, harga Rp 4.000,00 per kantong; mengandung tiga satuan $A$, lima satuan $B$, dan satu satuan C. Tumbuh Mudah, harga Rp 3.000,00 per kantong, mengandung 2 satuan tiap nutrien. Jika petani ingin meminimalkan biaya dan kebutuhan nutrien tetap terjaga, maka berapa banyak kantong dar tiap merk yang harus dibeli ?

2. PT LAQUNATEKSTIL memiliki sebuah pabrik yang akan memproduksi 2 jenis produk, yaitu kain sutera dan kain wol. Untuk memproduksi kedua produk diperlukan bahan baku benang sutera, bahan baku benang wol dan tenaga kerja. Maksimum penyediaan benang sutera adalah $60 \mathrm{~kg}$ per hari, benang wol $30 \mathrm{~kg}$ per hari dan tenaga kerja 40 jam per hari. Kebutuhan setiap unit produk akan bahan baku dan jam tenaga kerja dapat dilihat dalam tabel berikut:

\begin{tabular}{|c|c|c|c|}
\hline \multirow{2}{*}{$\begin{array}{c}\text { Jenis Bahan } \\
\text { Baku dan } \\
\text { Tenaga Kerja }\end{array}$} & \multicolumn{2}{|c|}{$\begin{array}{c}\text { Kg Bahan Baku \& } \\
\text { Jamaga Kerja }\end{array}$} & \multirow{2}{*}{ Maksimum } \\
\cline { 2 - 4 } & Kain & Kain & Penyediaan \\
Wol & \\
\hline Benang Sutra & 2 & 3 & $60 \mathrm{~kg}$ \\
\hline Benang Wol & $?$ & 2 & $30 \mathrm{~kg}$ \\
\hline Tenaga Kerja & 2 & 1 & $40 \mathrm{~kg}$ \\
\hline
\end{tabular}

Teknik Optimasi 
3. PT. Tangguh memproduksi 2 macam produk yang dikerjakan secara manual. Setiap unit produk I memerlukan waktu 20 menit pada proses 2 dan 24 menit pada proses 3, sedangkan setiap unit produk II memerlukan waktu 15 menit pada proses 1,16 menit proses 2, dan 30 menit proses 3. Produk I memberikan keuntungan sebesar Rp.170/unit dan Rp.190/unit untuk produk II. Jam kerja per hari yang tersedia untuk proses 1 , 2, dan proses 3 masing-masing 1050 menit, 1600 menit, dan 2400 menit. Berapakah jumlah produk I dan II harus diproduksi agar keuntungan maksimal ?

4. "PT. Rakyat Bersatu" menghasilkan 2 macam produk. Baik produk I maupun produk II setiap unit laku Rp. 3000,-. Kedua produk tersebut dalam proses pembuatannya perlu 3 mesin. Produk I perlu 2 jam mesin A, 2 jam mesin B, dan 4 jam mesin C. Produk II perlu 1 jam mesin A, 3 jam mesin B, dan 3 jam mesin C. Tersedia 3 mesin A yang mampu beroperasi 10 jam per mesin per hari, tersedia 6 mesin B yang mampu beroperasi 10 jam per mesin per hari, dan tersedia 9 mesin C yang mampu beroperasi 8 jam per mesin per hari. Berikan saran kepada pimpinan "PT. Rakyat Bersatu" sehingga dapat diperoleh hasil 
penjualan yang maksimum ! Dan berapa unit produk I dan produk II harus diproduksi ?

Teknik Optimasi 


\section{A. Pendahuluan}

Metode simpleks ini adalah metode yang biasanya digunakan untuk memecahkan setiap permasalahan pada pemrogramman linear yang kombinasi variabelnya terdiri dari tiga variabel atau lebih. Diperkenalkan pada tahun 1947 oleh George B. Dantzig dan telah diperbaiki oleh beberapa ahli lain. Metode penyelesaian dari Metode Simpleks ini melalui perhitungan ulang (iteration) di mana langkah-langkah perhitungan yang sama diulang-ulang sampai solusi optimal diperoleh.

\section{B. Langkah-langkah metode simpleks}

Untuk menyelesaikan masalah maksimisasi maka program linier harus lebih dahulu ditulis dalam bentuk standar. Dengan bentuk standar dimaksudkan adalah permasalahan program linier yang berwujud permasalahan maksimisasi dengan batasan-batasan (kendala) yang bertanda kurang dari atau sama dengan ( $\leq$ ) yang menunjukkan keterbatasan sumber daya yang tersedia. Untuk bentuk-bentuk lain seperti masalah minimisasi maupun penyimpangan-penyimpangan lain dalam batasan-batasan yang berlaku akan dibicarakan tersendiri. 
Berikut merupakan langkah - langkah menggunakan metode simpleks yaitu :

1. Mengubah fungsi tujuan dan fungsi kendala

2. Menyusun persamaan - persamaan di dalam tabel

3. Memilih kolom kunci baris $\mathrm{Z}$ dengan bilangan negatif angka yang terbesar

4. Mencari nilai indeks (Nilai indeks= NK : nilai kolom kunci)

5. Memilih baris kunci (Nilai Indeks terkecil)

6. Menentukan angka kunci perpotongan kolom kunci dan baris kunci

7. Menentukan NBBK (Nilai Baris Baru Kunci)

NBBK = baris kunci : angka kunci

8. Mengubah nilai - nilai selain baris kunci sehingga nilai nilai kolom kunci (selalu baris kunci) $=0$,

Baris lama $=$ baris baru $-($ koefisien angka kolom kunci $x$ NBBK).

9. Melanjutkan perbaikan/pengulangan/iterasi

\section{Contoh Soal}

Selesaikan kasus berikut ini menggunakan metode simpleks :

Maksimum $z=8 x_{1}+9 x_{2}+4 x_{3}$

Kendala :

$$
\begin{aligned}
& x_{1}+x_{2}+2 x_{3} \leq 2 \\
& 2 x_{1}+3 x_{2}+4 x_{3} \leq 3
\end{aligned}
$$




$$
\begin{aligned}
& 7 x_{1}+6 x_{2}+2 x_{3} \leq 8 \\
& x_{1}, x_{2}, x_{3} \geq 0
\end{aligned}
$$

\section{Penyelesaian :}

1. Mengubah fungsi tujuan dan fungsi kendala Maksimum :

$$
\begin{aligned}
z & =8 x_{1}+9 x_{2}+4 x_{3} \\
z-8 x_{1}-9 x_{2}-4 x_{3} & =0
\end{aligned}
$$

Kendala :

$$
\begin{aligned}
& x_{1}+x_{2}+2 x_{3}+x_{4}=2 \\
& 2 x_{1}+3 x_{2}+4 x_{3}+x_{5}=3 \\
& 7 x_{1}+6 x_{2}+2 x_{3}+x_{6}=8 \\
& x_{1}, x_{2}, x_{3}, x_{4}, x_{5}, x_{6} \geq 0
\end{aligned}
$$

2. Menyusun persamaan - persamaan di dalam tabel

Beberapa istilah dalam Metode Simpleks yaitu :

- NK adalah nilai kanan persamaan, yaitu nilai di belakang tanda sama dengan ( =) .

- Variabel dasar adalah variabel yang nilainya sama dengan sisi kanan dari persamaan.

- $z=8 x_{1}+9 x_{2}+4 x_{3}$ diubah menjadi $z-8 x_{1}-9 x_{2}-4 x_{3}=0$

$x_{1}+x_{2}+2 x_{3} \leq 2$ menjadi $x_{1}+x_{2}+2 x_{3}+x_{4}=2$

$2 x_{1}+3 x_{2}+4 x_{3} \leq 3$ menjadi $2 x_{1}+3 x_{2}+4 x_{3}+x_{5}=3$

$7 x_{1}+6 x_{2}+2 x_{3} \leq 8$ menjadi $7 x_{1}+6 x_{2}+2 x_{3}+x_{6}=8$

$x_{1} x_{2}, x_{3} \geq 0$ 
Solusi / tabel awal simpleks :

\begin{tabular}{|r|r|r|r|r|r|r|r|r|r|}
\hline $\mathrm{VD}$ & $\mathrm{Z}$ & $\mathrm{X}_{1}$ & $\mathrm{X}_{2}$ & $\mathrm{X}_{3}$ & $\mathrm{X}_{4}$ & $\mathrm{X}_{5}$ & $\mathrm{X}_{6}$ & $\mathrm{NK}$ & Rasio \\
\hline $\mathrm{Z}$ & 1 & -8 & -9 & -4 & 0 & 0 & 0 & 0 & \\
\hline $\mathrm{X}_{4}$ & 0 & 1 & 1 & 2 & 1 & 0 & 0 & 2 & \\
\hline $\mathrm{X}_{5}$ & 0 & 2 & 3 & 4 & 0 & 1 & 0 & 3 & \\
\hline $\mathrm{X}_{6}$ & 0 & 7 & 6 & 2 & 0 & 0 & 1 & 8 & \\
\hline
\end{tabular}

Karena Nilai negatif terbesar ada pada kolom $\mathrm{X}_{2}$, maka kolom $\mathrm{X}_{2}$ adalah kolom kunci dan $\mathrm{X}_{2}$ adalah variabel masuk. Rasio=NK / kolom kunci. Nilai rasio terkecil maka disebut baris kunci. Nilai raiso terkecil adalah 1 bersesuaian dengan baris $X_{4}$, maka baris $X_{5}$ adalah baris kunci dan $X_{5}$ adalah variabel keluar. Angka kunci adalah 3.

Kolom kunci

\begin{tabular}{|r|r|r|r|r|r|r|r|r|r|}
\hline VD & $Z$ & $X_{1}$ & $X_{2}$ & $X_{3}$ & $X_{4}$ & $X_{5}$ & $X_{6}$ & NK & Rasio \\
\hline$Z^{2}$ & 1 & -8 & -9 & -4 & 0 & 0 & 0 & 0 & $\infty$ \\
\hline$X_{4}$ & 0 & 1 & 1 & 2 & 1 & 0 & 0 & 2 & 2 \\
\hline$X_{5}$ & 0 & 2 & 3 & 4 & 0 & 1 & 0 & 3 & 1 \\
& & & & & & & & & \\
\hline$X_{6}$ & 0 & 7 & 6 & 2 & 0 & 0 & 1 & 8 & $8 / 6$ \\
\hline
\end{tabular}




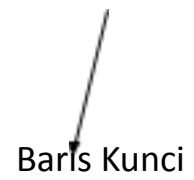

Angka Kunci

\section{Iterasi 1}

Nilai pertama yang kita miliki adalah Nilai Baris Baru Kunci (baris $X_{5}$ ). Semua nilai pada baris $X_{5}$ pada tabel solusi awal dibagi dengan 3 (angka kunci).

\begin{tabular}{|c|l|l|l|l|l|l|l|l|}
\hline $\mathrm{VD}$ & $\mathrm{X}_{1}$ & $\mathrm{X}_{2}$ & $\mathrm{X}_{3}$ & $\mathrm{X}_{4}$ & $\mathrm{X}_{5}$ & $\mathrm{X}_{6}$ & NK & Rasio \\
\hline $\mathrm{Z}$ & & & & & & & & \\
\hline $\mathrm{X}_{4}$ & & & & & & & & \\
\hline $\mathrm{X}_{2}$ & $2 / 3$ & 1 & $4 / 3$ & 0 & $1 / 3$ & 0 & 1 & \\
\hline $\mathrm{X}_{6}$ & & & & & & & & \\
\hline
\end{tabular}

NBBK $=$

Perhitungan nilai baris barunya :

Baris Z :

Teknik Optimasi 


$\begin{array}{cccccccc}-8 & -9 & 4 & 0 & 0 & 0 & 0 \\ -9(2 / 3 & 1 & 4 / 3 & 0 & 1 / 3 & 0 & 1)- \\ -2 & 0 & 8 & 0 & 3 & 0 & 9\end{array}$

Baris $\mathrm{X}_{4}$ :

$\begin{array}{ccccccc}1 & 1 & 2 & 1 & 0 & 0 & 2 \\ 1(2 / 3 & 1 & 4 / 3 & 0 & 1 / 3 & 0 & 1)- \\ 1 / 3 & 0 & 2 / 3 & 1 & 1 / 3 & 0 & 1\end{array}$

Baris $\mathrm{X}_{6}$ :

$\begin{array}{ccccccc}7 & 6 & 2 & 0 & 0 & 1 & 8 \\ 6(2 / 3 & 1 & 4 / 3 & 0 & 1 / 3 & 0 & 1)- \\ 3 & 0 & -6 & 0 & -2 & 1 & 2\end{array}$

\begin{tabular}{|c|c|c|c|c|c|c|c|c|c|}
\hline $\mathrm{VD}$ & $\mathrm{Z}$ & $\mathrm{X}_{1}$ & $\mathrm{X}_{2}$ & $\mathrm{X}_{3}$ & $\mathrm{X}_{4}$ & $\mathrm{X}_{5}$ & $\mathrm{X}_{6}$ & $\mathrm{NK}$ & Rasio \\
\hline $\mathrm{Z}$ & 1 & -2 & 0 & 8 & 0 & 3 & 0 & 9 & \\
\hline $\mathrm{X}_{4}$ & 0 & $1 / 3$ & 0 & $2 / 3$ & 1 & $-1 / 3$ & 0 & 1 & \\
\hline $\mathrm{X}_{2}$ & 0 & $2 / 3$ & 1 & $4 / 3$ & 0 & $1 / 3$ & 0 & 1 & \\
\hline $\mathrm{X}_{6}$ & 0 & 3 & 0 & -6 & 0 & -2 & 1 & 2 & \\
\hline
\end{tabular}

Maka tabel iterasi 1 ditunjukkan tabel di atas. Selanjutnya kita periksa apakah tabel sudah optimal atau belum. Karena nilai baris $Z$ di bawah variabel $X_{1}$ masih negatif, maka tabel 
belum optimal. Kolom dan baris kuncinya ditandai pada tabel di bawah ini :

\begin{tabular}{|c|c|c|c|c|c|c|c|c|c|}
\hline $\mathrm{VD}$ & $\mathrm{Z}$ & $\mathrm{X}_{1}$ & $\mathrm{X}_{2}$ & $\mathrm{X}_{3}$ & $\mathrm{X}_{4}$ & $\mathrm{X}_{5}$ & $\mathrm{X}_{6}$ & $\mathrm{NK}$ & Rasio \\
\hline $\mathrm{Z}$ & 1 & -2 & 0 & 8 & 0 & 3 & 0 & 9 & - \\
\hline $\mathrm{X}_{4}$ & 0 & $1 / 3$ & 0 & $2 / 3$ & 1 & $-1 /$ & 0 & 1 & 3 \\
& & & & & & 3 & & & \\
\hline $\mathrm{X}_{2}$ & 0 & $2 / 3$ & 1 & $4 / 3$ & 0 & $1 / 3$ & 0 & 1 & $3 / 2$ \\
\hline $\mathrm{X}_{6}$ & 0 & 3 & 0 & -6 & 0 & -2 & 1 & 2 & $2 / 3$ \\
\hline
\end{tabular}

Variabel masuk dengan demikian adalah $X_{1}$ dan variabel keluar adalah $\mathrm{X}_{6}$. Hasil perhitungan iterasi ke 2 adalah sebagai berikut :

Iterasi 2 :

\begin{tabular}{|c|r|r|r|r|r|r|r|r|}
\hline VB & $X_{1}$ & $X_{2}$ & $X_{3}$ & $X_{4}$ & $X_{5}$ & $X_{6}$ & NK & Rasio \\
\hline$Z$ & 0 & 0 & 4 & 0 & $5 / 3$ & $2 / 3$ & $31 / 3$ & \\
\hline$X_{4}$ & 0 & 0 & $4 / 3$ & 1 & $-1 / 9$ & $-1 / 9$ & $7 / 9$ & \\
\hline$X_{2}$ & 0 & 1 & $8 / 3$ & 0 & $7 / 9$ & $-2 / 9$ & $5 / 9$ & \\
\hline$X_{1}$ & 1 & 0 & -2 & 0 & $-2 / 3$ & $1 / 3$ & $2 / 3$ & \\
\hline
\end{tabular}

Teknik Optimasi 
Tabel sudah optimal, sehingga perhitungan iterasi dihentikan. Jadi $X_{1}=2 / 3, X_{2}=-2 / 9$ dan $Z$ max $=31 / 3$.

Perhitungan dalam simpleks menuntut ketelitian tinggi, khususnya jika angka yang digunakan adalah pecahan. Pembulatan harus diperhatikan dengan baik. Disarankan jangan menggunakan bentuk bilangan desimal, akan lebih teliti jika menggunakan bilangan pecahan. Pembulatan dapat menyebabkan iterasi lebih panjang atau bahkan tidak selesai karena ketidaktelitian dalam melakukan pembulatan.

Perhitungan iteratif dalam simpleks pada dasarnya merupakan pemeriksaan satu per satu titik-titik ekstrim layak pada daerah penyelesaian. Pemeriksaan dimulai dari kondisi nol (dimana semua aktivitas/variabel keputusan bernilai nol). Jika titik ekstrim berjumlah n, kemungkinan terburuknya kita akan melakukan perhitungan iteratif sebanyak $\mathrm{n}$ kali.

\section{Penyimpangan-penyimpangan dari bentuk standart}

Pada permasalahan minimisasi, biasanya kita jumpai tanda $\geq$ pada fungsi kendala. Kendati demikian tidak menutup

Teknik Optimasi 
kemungkinan fungsi kendala mempunyai tanda $=$. Dalam menyelesaikan permasalahan LP (Linier Program) dengan metode simpleks, langkah pertama yang harus kita lakukan adalah menyesuaikan formulasi permasalahan dengan standard simpleks. Dengan kata lain kita harus merubah tanda pertidaksamaan menjadi persamaan.

Pada fungsi kendala dengan tanda $\leq$ kita harus menambahkan slack variabel yang menyatakan kapasitas yang tidak digunakan atau yang tersisa pada departemen tersebut. Hal ini karena ada kemungkinan kapasitas yang tersedia tidak semuanya digunakan dalam proses produksi. Pada permasalahan minimisasi kita jumpai fungsi kendala dengan tanda $\geq$, artinya bahwa kita dapat menggunakan sumber daya lebih dari yang tersedia. Pertanyaan yang muncul adalah berapa besarnya kelebihan sumber daya yang telah kita gunakan dari yang tersedia. Untuk menyatakan kelebihan sumber daya yang digunakan dari yang tersedia ini, maka kita harus mengurangi kendala tersebut dengan surplus variabel. Surplus variabel ini sering disebut sebagai slack variabel yang negatif.

Karena nilai solusi pada permasalahan LP harus non-negatif maka untuk mengatasi masalah ini kita harus menambahkan artificial variabel (A). Artificial variabel ini secara phisik tidak 
mempunyai arti, dan hanya digunakan untuk kepentingan perhitungan saja.

\section{Contoh Soal :}

Minimumkan : $Z=7 X_{1}+3 X_{2}$

Kendala :

$4 X_{1}+6 X_{2} \leq 36$

$7 X_{1}+5 X_{2}=35$

$8 X_{1}+4 X_{2} \geq 32$

$X_{1}, X_{2} \geq 0$

- Pada fungsi kendala yang pertama, untuk mengubah menjadi persamaan harus ditambah variabel slack, yang sekaligus digunakan sebagai basis pada tabel awal simpleks. Persamaan tersebut menjadi:

$4 \times 1+6 \times 2+S 1=36$.

- Pada fungsi kendala yang kedua sudah dalam bentuk persamaan, karena belum ada variabel yang merupakan basis pada tabel awal, maka perlu ada variabel dummy (variabel buatan) yang disebut variabel artificial (lambang "R"). Dinamakan artificial karena tidak mempunai arti nyata, artinya iterasi-iterasi metode simpleks akan secara otomatis menjadikan variabel artificial tidak muncul lagi (bernilai nol) yaitu apabila persoalan semula yang telah terselesaikan. Dengan kata lain variabel artificial ini digunakan hanya untuk 
memulai solusi dan harus menghilangkanya pada akhir solusi. Jika tidak demikian, maka solusi yang diperoleh akan tidak layak. Untuk itu persamaan pembatas kedua diatas akan menjadi:

$7 X_{1}+5 X_{2}+R_{1}=35$.

- Sedangkan fungsi pembatas ketiga yang bertanda " $\geq$ ", maka harus diubah menjadi tanda " $\leq$ " dan akhirnya menjadi tanda "=" agar dapat diselesaikan dengan metode simpleks. Persamaan tersebut dikalikan (-1) akan menjadi : $-8 X_{1}-4 X_{2} \leq$ -32. Kemudian, ubah ke tanda sama dengan seperti yang telah dibahas diatas maka menjadi : $-8 X_{1}-4 X_{2}+S_{2}=-32$. Karena bagian kanan persamaan ini bertanda negatif (-32), maka harus menjadi $8 X_{1}+4 X_{2}-S_{2}=32$, tetapi karena $\mathrm{S}_{1}$ bertanda negatif, hal ini tidak memungkinkan dalam metode simpleks karena tidak dapat digunakan sebagai basis pada tabel awal. Untuk itu harus ditambahkan variabel artificial $R$, sehingga persamaan pembatas ketiga tersebut menjadi:

$8 X_{1}+4 X_{2}-S_{2}+R_{2}=32$.

- Dari pembahasan mengenai variabel slack dan variabel artificial berkaitan dengan metode simpleks dapat disimpulkan bahwa : 
1. Apabila fungsi kendala bertanda $\leq$, maka tambahkan variabel slack.

2. Apabila fungsi kendala bertanda $=$, maka tambahkan variabel artificial $R$.

3. Apabila fungsi kendala bertanda $\geq$, maka kurangi dengan variabel slack dan tambahkan variabel artificial $\mathrm{R}$.

4. Apabila fungsi kendala adalah negatif, maka harus diubah menjadi positif dengan mengalikan (-1) dan sesuaikan dengan ketiga kesimpulan diatas.

Formulasi yang sudah mengalami modifikasi ini disebut formulasi dalam bentuk standar metode simpleks. Sehingga soal diatas bentuk standarnya adalah :

Minimumkan : $Z=7 X_{1}+3 X_{2}$

\section{Kendala :}

$$
\begin{aligned}
& 4 X_{1}+6 X_{2}+S_{1}=36 \\
& 7 X_{1}+5 X_{2}+R_{1}=35 \\
& 8 X_{1}+4 X_{2}-S_{2}+R_{2}=32 \\
& X_{1}, X_{2}, S_{1}, S_{2}, R_{1}, R_{2} \geq 0
\end{aligned}
$$

Penyelesaian persoalan yang mengandung variabel artificial ini dapat dilakukan dengan Metode Big M. 


\section{Teknik The Big M (Metode Penalty) :}

Pada teknik ini, setiap variabel artificial dalam fungsi tujuan diberikan penalty $M$, dimana $M$ merupakan bilangan positif yang sangat besar. Penalty bertanda negatif (-) apabila fungsi tujuan maksimasi dan bertanda positif (+) apabila fungsi tujuan minimasi.

Persamaan menurut contoh diatas menjadi :

Minimumkan : $Z=7 X_{1}+3 X_{2}+0 S_{1}+0 S_{2}+M R_{1}+M R_{2}$

Kendala :

$$
\begin{aligned}
& 4 X_{1}+6 X_{2}+S_{1}=36 \\
& 7 X_{1}+5 X_{2}+R_{1}=35 \\
& 8 X_{1}+4 X_{2}-S_{2}+R_{2}=32 \\
& X_{1}, X_{2}, S_{1}, S_{2}, R_{1}, R_{2} \geq 0
\end{aligned}
$$

Untuk memasukan model matematis persoalan diatas dalam tabel simpleks, maka terlebih dahulu melakukan subtitusi nilai $R_{1}$ dan $R_{2}$ pada persamaan kendala dan pada persamaan fungsi tujuan $Z$ diatas yaitu :

$$
\begin{aligned}
& R_{1}=35-7 X_{1}-5 X_{2} \\
& R_{2}=32-8 X_{1}-4 X_{2}+S_{2}
\end{aligned}
$$

Kemudian $R_{1}$ dan $R_{2}$ tersebut dimasukan kedalam persamaan Z menjadi :

$$
Z=7 X_{1}+3 X_{2}+M R_{1}+M R_{2}
$$

Teknik Optimasi 


$$
\begin{aligned}
& Z=7 X_{1}+3 X_{2}+M\left(35-7 X_{1}-5 X_{2}\right)+M\left(32-8 X_{1}-4\right. \\
& \left.X_{2}+S_{2}\right) \\
& Z=(7-7 M-8 M) X_{1}+(3-5 M-4 M) X_{2}+M S_{2}+ \\
& (35 M+32 M) \\
& Z=(7-15 M) X_{1}+(3-9 M) X_{2}+M S_{2}+67 M \\
& Z+(15 M-7) X_{1}+(9 M-3) X_{2}-M S_{2}=67 M
\end{aligned}
$$

Berdasarkan persamaan terakhir ini maka dilakukan penyelesaian dengan metode simpleks seperti cara penyelesaian yang sudah diuraikan pada bagian sebelumnya tentang pemecahan program linear metode simpleks.

Iterasi awal hingga iterasi akhir optimal penyelesaian persoalan diatas dapat dilihat pada tabel berikut :

\begin{tabular}{|l|l|l|l|l|l|l|l|l|l|}
\hline Iterasi & Basis & $\mathbf{Z}$ & $\mathbf{X}_{\mathbf{1}}$ & $\mathbf{X}_{\mathbf{2}}$ & $\mathbf{S}_{\mathbf{1}}$ & $\mathbf{R}_{\mathbf{1}}$ & $\mathbf{S}_{\mathbf{2}}$ & $\mathbf{R}_{\mathbf{2}}$ & Solusi \\
\hline & $\mathbf{Z}$ & 1 & $\begin{array}{c}(15 \mathrm{M} \\
-7)\end{array}$ & $\begin{array}{c}(9 \mathrm{M} \\
-3)\end{array}$ & 0 & 0 & $-\mathrm{M}$ & 0 & $67 \mathrm{M}$ \\
\cline { 2 - 10 } $\mathbf{0}$ & $\mathbf{S}_{\mathbf{1}}$ & 0 & 4 & 6 & 1 & 0 & 0 & 0 & 36 \\
\cline { 2 - 10 } & $\mathbf{R}_{\mathbf{1}}$ & 0 & 7 & 5 & 0 & 1 & 0 & 0 & 35 \\
\cline { 2 - 10 } & $\mathbf{R}_{\mathbf{2}}$ & 0 & 8 & 4 & 0 & 0 & -1 & 1 & 32 \\
\hline
\end{tabular}

Teknik Optimasi 


\begin{tabular}{|c|c|c|c|c|c|c|c|c|c|}
\hline Iterasi & Basis & Z & $X_{1}$ & $x_{2}$ & $S_{1}$ & $R_{1}$ & $S_{2}$ & $\mathbf{R}_{\mathbf{2}}$ & Solusi \\
\hline \multirow{4}{*}{1} & Z & 1 & 0 & $\begin{array}{l}\text { (3M } \\
+ \\
1) / 2\end{array}$ & 0 & 0 & $\begin{array}{l}(7 \mathrm{M} \\
- \\
7) / 8\end{array}$ & $\begin{array}{l}-(15 \\
M- \\
7) / 8\end{array}$ & $\begin{array}{l}7 M+ \\
28\end{array}$ \\
\hline & $S_{1}$ & 0 & 0 & 4 & 1 & 0 & $1 / 2$ & $-1 / 2$ & 20 \\
\hline & $\mathbf{R}_{1}$ & 0 & 0 & $3 / 2$ & 0 & 1 & $7 / 8$ & $-7 / 8$ & 7 \\
\hline & $X_{1}$ & 0 & 1 & $1 / 2$ & 0 & 0 & $\begin{array}{l}-1 / \\
8\end{array}$ & $1 / 8$ & 4 \\
\hline
\end{tabular}

\begin{tabular}{|l|l|l|l|l|l|l|l|l|l|}
\hline Iterasi & Basis & $\mathbf{Z}$ & $\mathbf{X}_{\mathbf{1}}$ & $\mathbf{X}_{\mathbf{2}}$ & $\mathbf{S}_{\mathbf{1}}$ & $\mathbf{R}_{\mathbf{1}}$ & $\mathbf{S}_{\mathbf{2}}$ & $\mathbf{R}_{\mathbf{2}}$ & Solusi \\
\hline $\mathbf{2}$ & $\mathbf{Z}$ & 1 & 0 & 0 & 0 & - & $-7 / 6$ & $\begin{array}{l}-\mathrm{M}+ \\
7 / 6\end{array}$ & $77 / 3$ \\
& & & & & & $1 / 3$ & & & \\
\cline { 2 - 8 } & $\mathbf{S}_{1}$ & 0 & 0 & 0 & 1 & 3 & 6 & $11 / 6$ & $4 / 3$ \\
\hline
\end{tabular}

Teknik Optimasi 


\begin{tabular}{|l|l|l|l|l|l|l|l|l|l|}
\hline & $x_{2}$ & 0 & 0 & 1 & 0 & $2 / 3$ & $7 / 12$ & $-7 / 1$ & 2 \\
\hline & $x_{1}$ & 0 & 1 & 0 & 0 & $\begin{array}{l}-1 / \\
3\end{array}$ & $\begin{array}{l}-5 / 1 \\
2\end{array}$ & $5 / 12$ & $5 / 3$ \\
\hline
\end{tabular}

Dari iterasi ke-2 pada tabel diatas merupakantabel optimal sehingga diketahui nilai optimal untuk $X_{1}=5 / 3, X_{2}=14 / 3, X_{3}=0, S_{1}=4 / 3$, dan $\mathrm{Zmin}=77 / 3$.

\section{Latihan soal}

1. PT Unilever bermaksud membuat 2 jenis sabun, yakni sabun bubuk dan sabun batang. Untuk itu dibutuhkan 2 macam zat kimia, yakni A dan B. Jumlah zat kimia yang tersedia adalah $A$ $=200 \mathrm{Kg}$ dan $\mathrm{B}=360 \mathrm{Kg}$. Untuk membuat $1 \mathrm{Kg}$ sabun bubuk diperlukan $2 \mathrm{Kg} \mathrm{A}$ dan $6 \mathrm{Kg}$ B. Untuk mebuat $1 \mathrm{Kg}$ sabun batang diperlukan $5 \mathrm{Kg} \mathrm{A}$ dan $3 \mathrm{Kg}$ B. Bila keuntungan yang akan diperoleh setiap membuat $1 \mathrm{Kg}$ sabun bubuk $=\$ 3$ sedangkan setiap $1 \mathrm{Kg}$ sabun batang $=\$ 2$, berapa $\mathrm{Kg}$ jumlah sabun bubuk dan sabun batang yang sebaiknya dibuat?

2. Perusahaan Brilliant menghasilkan 2 jenis sepatu yaitu sepatu dengan merk italy dan felix. Merk italy dibuat dengan sol dari bahan karet. Sedangkan felix dibuat dengan sl dari bahan 
kulit. Untuk membuat sepatu tersebut diperlukan 3 jenis mesin yaitu $A$ (khusus untuk sol karet), $B$ (khusus untuk sol kulit), dan C (untuk finishing). Untuk setiap lusin sepatu dibutuhkan waktu :

- Italy dikerjakan pada mesin A selama 2 jam tanpa melalui mesin B dan di mesin C selama 6 jam

- Felix dikerjakan tanpa melalui mesin $A$, melalui mesin B selama 3 jam dan mesin C selama 5 jam.

Jam kerja maksimum setiap hari untuk mesin $A=8$ melalui mesin $B=15$ jam, dan mesin $C=30$ jam. Perolehan keuntungan untuk setiap lusin sepatu italy Rp. 30.000,00 dan felix Rp. 50.000,00. Tentukan jumlah produksi sepatu yang menghasilkan laba maksimal !

3. PT. Eb07 akan membuat kain sutra dan kain wol, yang terbuat dari benang sutra $3 \mathrm{Kg}$ untuk pembuatan kain sutra dan benang sutra $4 \mathrm{Kg}$ dan benang wol $1 \mathrm{Kg}$ untuk pembuatan kain wol. Masing - masing membutuhkan masa kerja 2 jam untuk kain sutra dan kain wol. Benang sutra kurang dari 120 $\mathrm{Kg}$, benang wol kurang dari $20 \mathrm{Kg}$ dan masa kerja kurang dari 40 jam. Berapakah yang harus diproduksi PT. Eb07 untuk mendapatkan laba maksimal dengan $\left(Z=30 X_{1}+40 X_{2}\right)$ ?

4. PT Yummy food memiliki sebuah pabrik yang akan memproduksi dua jenis produk yaitu vanila dan violet. Untuk 
memproduksi kedua produk tersebut diperlukan bahan baku $A$, bahan baku B dan jam tenaga kerja. Maksimum pengerjaan bahan baku A adalah $60 \mathrm{~kg}$ per hari, bahan baku B $30 \mathrm{~kg}$ per hari dan tenaga kerja 40 jam per hari. Kedua jenis produk memberikan sumbangan keuntungan sebesar Rp.40,00 untuk vanila dan Rp.30,00 untuk violet. Masalah yang dihadapi adalah bagaimana menentukan jumlah unit setiap produk yang akan diproduksi setiap hari. 


\section{A. Teori Dualitas}

Dalam sebuah pemodelan program linear, terdapat dua konsep yang saling berlawanan. Konsep yang pertama kita sebut Primal dan yang kedua Dual. Bentuk Dual adalah kebalikan dari bentuk Primal. Hubungan Primal dan Dual sebagai berikut:

\begin{tabular}{|c|l|l|}
\hline & \multicolumn{1}{|c|}{ Masalah Primal } & \multicolumn{1}{c|}{ Masalah Dual } \\
\hline 1. & Koefisien fungsi tujuan & Nilai kanan fungsi batasan \\
\hline 2. & Maksimumkan Z & Minimumkan $\mathrm{Y}$ \\
\hline 3. & Batasan $\mathrm{i}$ & Variabel yi \\
\hline 4. & Bentuk $\leq$ & $Y i \geq 0$ \\
\hline 5. & Bentuk $=$ & Yi $\geq 0$ dihilangkan \\
\hline 6. & Variabel $\mathrm{xi}$ & Batasan $\mathrm{j}$ \\
\hline 7. & $\mathrm{Xj} \geq 0$ & Bentuk $\geq$ \\
\hline 8. & $\mathrm{Xj} \geq 0$ dihilangkan & Bentuk $=$ \\
\hline
\end{tabular}

\section{Contoh:}

Teknik Optimasi 
- Primal

Minimumkan Z: $5 x_{1}+2 x_{2}+x_{3}$

Fungsi batasan:

1) $2 x_{1}+3 x_{2}+x_{3} \geq 20$

2) $6 x_{1}+8 x_{2}+5 x_{3} \geq 30$

3) $7 x_{1}+x_{2}+3 x_{3} \geq 40$

$x_{1}, x_{2}, x_{3} \geq 0$

- Dual

Maksimumkan Y: $20 \mathrm{y}_{1}+30 \mathrm{y}_{2}+40 \mathrm{y}_{3}$

Fungsi batasan:

1) $2 y_{1}+6 y_{2}+7 y_{3} \leq 5$

2) $3 y_{1}+8 y_{2}+y_{3} \leq 2$

3) $y_{1}+5 y_{2}+3 y_{3} \leq 1$

$\mathrm{y}_{1}, \mathrm{y}_{2}, \mathrm{y}_{3} \geq 0$

Persoalan utama (primal problem) adalah persoalan yang dihadapi oleh suatu perusahaan (misal perusahaan A) yang ingin memproduksi beberapa macam barang sehingga dapat dicapai keuntungan atau laba maksimum.

Persoalan rangkap (dual problem) adalah persoalan yang dihadapi perusahaan lain (perusahaan B) yang ingin membeli bahan mentah dari $A$ dan ingin menawarkan harga sebesar $\mathbf{w}_{i}$ untuk resources (input) ke- $i$ yang sekaligus ingin membuat imputed prices menjadi minimum.

Teknik Optimasi 
Jika persoalan asli dapat diselesaikan yaitu solusi yang optimal telah diperoleh, maka pemecahan persoalan rangkap dapat dengan mudah dilakukan, dengan menggunakan sebuah teorema:

\section{Maksimum $Z=$ Minimum $Y$}

\section{B. Analisa Sensivitas}

Analisis sensitivitas berkaitan dengan perubahan koefisien fungsi tujuan terhadap solusi optimal. Analisis ini terbagi dua yaitu:

a) Analisis Sensitivitas: Reduced Cost dan Penentuan Kelayakan Penambahan Produk Baru

Reduced cost adalah besarnya perubahan nilai optimal fungsi tujuan jika produk yang mestinya tidak diproduksi $(T)$ tetap diproduksi. Variabel yang tidak berada pada kolom product mix pada table optimal, disebut non basic variabel. Dengan demikian, $T$ merupakan non-basicvariable.

Reduce cost adalah perubahan dalam nilai optimal fungsi tujuan karena penambahan 1 unit non-basic variabel. Reduced cost ini dapat dilihat pada baris $C_{j}-Z_{j}$ kolom non-basic variabel. Dalam memutuskan apakah akan menambah produk baru ataukah tidak,perusahaan harus mempertimbangkan faktor biaya dan keuntungan dari adanya penambahan produk baru tersebut. Jika keuntungan > biaya, sebaiknya 
rencana penambahan produk baru diteruskan, dan apabila keuntungan $<$ biaya sebaiknya dibatalkan.

Untuk penentuan kelayakan penambahan produk baru, jika perusahaan merencanakan untuk meluncurkan produk baru yang diproses dengan menggunakan mesin yang sudah ada, apakah produk tersebut layak untuk diproduksi? Untuk menjawab pertanyaan ini, kita perlu mengevaluasi kelayakan produk tersebut dengan mempertimbangkan cost and benefit dengan adanya penambahan produk baru tersebut. Apabila benefit lebih besar daripada cost yang dikeluarkan, maka produk layak untuk diproduksi. Demikian jika terjadi sebaliknya, maka produk baru tidak diproduksi.

b) Analisis Sensitivitas: Rentang Perubahan Koefisien Fungsi Tujuan

Koefisien fungsi tujuan mungkin saja berubah terlebih untuk kasus maksimisasi profit, dimana koefisien fungsi tujuan mencerminkan besarnya keuntungan per unit produk. Sehingga jika terjadi kenaikan biaya, sementara tingkat harga tetap akan mengakibatkan keuntungan per unit turun. Dengan kata lain, koefisien fungsi tujuan turun. Sebaliknya apabila terjadi kenaikan harga, sementara biaya tetap, maka akan mengakibatkan keuntungan perunit naik. Ini berarti koefisien fungsi tujuan naik.

Teknik Optimasi 
Dalam analisis sensitivitas, perlakuan antara basic variable dan nonbasic variabel berbeda. Untuk non-basic variabel batas maksimum yang diperkenankan agar solusi masih tetap optimal tercermin pada baris $Z_{j}$ kolom non-basic variabel pada tabel optimal.

Sedangkan untuk mengetahui rentang perubahan koefisien fungsi tujuan untuk basic variable kita bagian angka-angka pada baris $C_{j}-Z_{j}$ dengan angka-angka pada baris basic variabel yang sedang kita analisa. Hasil bagi positif terkecil menunjukkan besarnya keuntungan per unit yang boleh dinaikkan dan hasil bagi negatif terkecil menunjukkan besarnya keuntungan per unit yang boleh diturunkan tanpa merubah solusi optimal.

\section{Latihan Soal}

1. Primal

Maksimumkan $Z=5 X_{1}+7 X_{2}$ Fungsi batasan:
1) $2 X_{1}+X_{2} \leq 8$
2) $X_{1}+2 X_{2} \leq 8$
3) $6 X_{1}+7 X_{2} \leq 42$
$X_{1}, X_{2}, X_{3} \geq 0$

2. Primal

Teknik Optimasi 
Maksimumkan $Z=X_{1}+3 X_{2}-2 X_{3}$

Fungsi batasan:

$$
\begin{array}{cl}
\text { 1) } 4 X_{1}+8 X_{2}+6 X_{3} & =25 \\
\text { 2) } 7 X_{1}+5 X_{2}+9 X_{3} & =30 \\
X_{1}, X_{2}, X_{3} \geq 0 &
\end{array}
$$

3. Primal

Minimumkan $Z=3 X_{1}+2 X_{2}+X_{3}+2 X_{4}+3 X_{5}$

Fungsi batasan:

1)

$$
2 X_{1}+5 X_{2}+4 X_{4}+X_{5} \quad \geq 6
$$

2) $4 \mathrm{X}_{2}-2 \mathrm{X}_{3}+2 \mathrm{X}_{4}+3 \mathrm{X}_{5} \geq 5$

3)

$$
\begin{aligned}
& X_{1}-6 X_{2}+3 X_{3}+7 X_{4}+5 X_{5} \leq 7 \\
& X_{1}, X_{2}, X_{3}, X_{4}, X_{5} \geq 0
\end{aligned}
$$




\section{A. Pendahuluan}

Transportasi merupakan suatu perpindahan barang dari suatu tempat menuju tempat lainnya. Seiring dengan peningkatan kebutuhan masyarakat maka aktivitas transportasi pun juga meningkat. Hal ini di sebabkan adanya pergerakan menuju daerah pemenuhan kebutuhan yang berbeda-beda. Hal ini menjadikan transportasi sangat penting dalam menunjang aktivitas masyarakat dan turut menentukan perkembangan suatu wilayah. Dengan adanya transportasi yang lancar maka distribusi barang dan jasa juga akan semakin mudah.

Sasaran transportasi adalah mengalokasikan produk yang ada pada sumber asal sedemikian rupa hingga terpenuhi semua kebutuhan pada tempat tujuan. Sedangkan tujuan utama dari persoalan transportasi adalah untuk mencapai biaya yang serendah-rendahnya (minimum) atau mencapai jumlah laba yang sebesar-besarnya (maksimal). Persoalan transportasi terdapat pada pemilihan rute dalam jaringan distribusi produk antara pusat 
industri dan distribusi gudang atau antara distribusi gudang regional dan distribusi pengeluaran lokal.

Masalah transportasi sering disebut sebagai masalah khusus dalam pemrograman linear, karena dalam struktur modelnya terdapat bagian yang menggambarkan sisi permintaan dan sisi penawaran. Sesuai dengan namanya, model ini berkaitan dengan penentuan rencana biaya terendah untuk mengirim susuatu dari sejumlah sumber ke sejumlah tujuan.

Proyek konstruksi membutuhkan transportasi sehingga dapat mendistribusikan material pembangunan maupun alat ke lokasi pekerjaan dan sebaliknya. Sebagai bagian dari pengendalian proyek konstruksi dibutuhkan adanya perencanaan biaya yang optimal sehingga tidak terjadi pemborosan anggaran dengan maksud sisa anggaran dapat digunakan untuk kegiatan lainnya.

Alokasi produk ini harus diatur sedemikian rupa karena terdapat perbedaan biaya-biaya alokasi dari satu sumber atau beberapa sumber ke tempat tujuan yang berbeda.

\section{B. Metode Stepping Stone}

Suatu metode yang digunakan untuk mengatur distribusi dari sumber-sumber yang menyediakan produk yang sama, ke tempat- tempat yang membutuhkan secara optimal. 


\section{Langkah Pengerjaan}

1. Diawali mengisi tabel menggunakan salah satu metode transportasi awal atau initial solution. Yang dapat berupa :

$\rightarrow$ NWCR (North West Corner Rule)

$\rightarrow$ VAM (Vogel Approximation Method)

$\rightarrow$ LC (Least Cost)

2. Melakukan evaluasi sel kosong, caranya :

- Melakukan lompatan secara horizontal / vertikal secara bergantian, dengan ber pijak pada sel yang sudah terisi.

- Lompatan dilakukan sampai kembali ke sel kosong yang ingin diuji.

3. Melakukan perhitungan biaya pada sel kosong tersebut. Dimulai dari sel yang kosong dan dilanjutkan dengan sel-sel yang dilompatinya, dimana sel kosong diberi nilai positif, lompatan pertama diberi nilai negatif, lompatan kedua diberi nilai positif, dan seterusnya secara bergantian.

4. Jika semua hasil perhitungan pada evaluasi sel kosong bernilai positif, maka tabel transportasi sudah minimum. Tetapi, jika ada nilai negatif, maka tabel transportasi belum minimum dan akan dipilih negatif terbesar.

5. Setelah dipilih perhitungan biaya yang menghasilkan angka negatif terbesar, pilih sel dengan unit terkecil pada lompatan yang bernilai negatif. Tambahkan unit terkecil tersebut ke 
lompatan yang bernilai positif, dan kurangkan ke lompatan yang bernilai negatif.

6. Ulangi langkah kedua sampai keempat sampai tidak ada nilai negatif pada evaluasi sel kosong.

\section{Contoh Soal}

Dounkey Corp. sedang merencanakan untukmengalokasikan produk yang dihasilkan ke kota A, B, dan C. Berikut tabel transportasi yang sudah disusun oleh manajer Dounkey Corp. (Biaya dalam \$, permintaan dan kapasitas dalam unit).

Tabel transportasi Dounkey Corp.

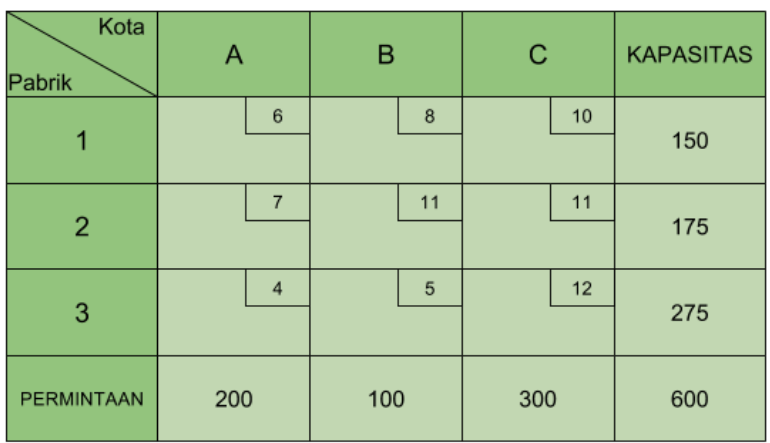

\section{Penyelesaian:}

Gunakan metode NWCR (North West Corner Rule) untuk mencari Solusi Awal (Initial Solution) dari metode transportasi. Sehingga didapatkan tabel transportasinya sebagai berikut : 


\begin{tabular}{|c|c|c|c|c|c|c|c|}
\hline \multirow[t]{2}{*}{ Kota } & \multicolumn{2}{|l|}{ A } & \multicolumn{2}{|c|}{ B } & \multicolumn{2}{|c|}{ C } & KAPASITAS \\
\hline & 150 & 6 & \multicolumn{2}{|r|}{8} & \multicolumn{2}{|r|}{10} & 150 \\
\hline 2 & 50 & 7 & 100 & 11 & 25 & 11 & 175 \\
\hline 3 & - & 4 & - & 5 & 275 & 12 & 275 \\
\hline PERMINTAAN & 200 & & 10 & & & & 600 \\
\hline
\end{tabular}

Karena metode NWCR merupakan solusi awal, sehingga diperlukan perhitungan lebih lanjut dengan solusi akhir metode Stepping Stone agar biayanya minimum.

\section{Langkah-langkah:}

1. Evaluasi sel kosong

Melakukan evaluasi sel kosong, dengan menghitung lompatan biaya dari sel kosong ke sel yang ada isi. Dan kemudian baru dihitung biayanya, dimana sel kosong diberi nilai positif, lompatan pertama diberi nilai negatif, lompatan kedua diberi nilai positif, dan seterusnya.

Contoh Ilustrasinya untuk 1-B :

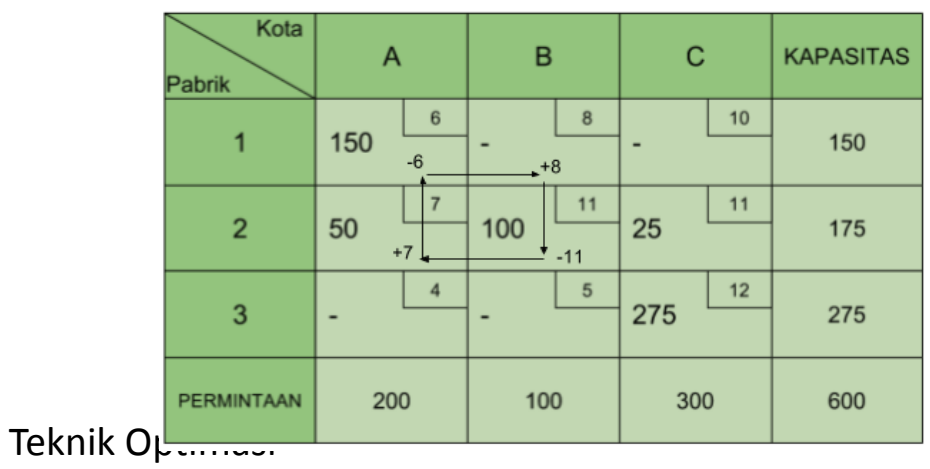


$1-B=8-11+7-6=-2$

$1-\mathrm{C}=10-11+7-6=0$

$3-\mathrm{A}=4-7+11-12=-4$

$3-B=5-11+11-12=-7^{*}$

Masih terdapat nilai yang negatif, maka dipilih nilai negatif terbesar yaitu -7 pada pengiriman pabrik 3 ke kota B.

\section{Pilih sel nilai negatif terbesar}

Setelah dipilih perhitungan biaya yang menghasilkan angka negatif terbesar, pilih sel dengan unit terkecil pada lompatan yang bernilai negatif, dimana dalam hal ini adalah 100. Tambahkan unit terkecil tersebut ke lompatan yang bernilai positif, dan kurangkan ke lompatan yang bernilai negatif. Sehingga didapatkan :

3. Lakukan evaluasi sel kosong untuk kedua kalinya

$1-B=8-5+12-11+7-6=5$

$1-C=10-11+7-6=0$

$2-\mathrm{B}=11-5+12-11=7$

$3-A=4-7+11-12=-4$ *

Masih terdapat nilai negatif, maka dipilih negatif terbesar yaitu -4 pada pengiriman dari pabrik 3 ke kota $A$

\begin{tabular}{|c|c|c|c|c|c|c|c|c|}
\hline \multirow{5}{*}{ Teknik Optir } & Kota & \multicolumn{2}{|l|}{ A } & \multicolumn{2}{|c|}{ B } & \multicolumn{2}{|c|}{ C } & KAPASITAS \\
\hline & 1 & \multicolumn{2}{|l|}{150} & - & 8 & & 10 & 150 \\
\hline & 2 & 50 & 7 & \multicolumn{2}{|l|}{100} & \multicolumn{2}{|l|}{25} & 175 \\
\hline & 3 & - & 4 & - & 5 & 275 & 12 & 275 \\
\hline & PERMINTAAN & 200 & & & & $3 c$ & & 600 \\
\hline
\end{tabular}




\section{Pilih sel nilai negatif terbesar}

Setelah dipilih perhitungan biaya yang menghasilkan angka negatif terbesar, pilih sel dengan unit terkecil pada lompatan yang bernilai negatif, dimana dalam hal ini adalah 50. Tambahkan unit terkecil tersebut ke lompatan yang bernilai positif, dan kurangkan ke lompatan yang bernilai negatif. Sehingga didapatkan :

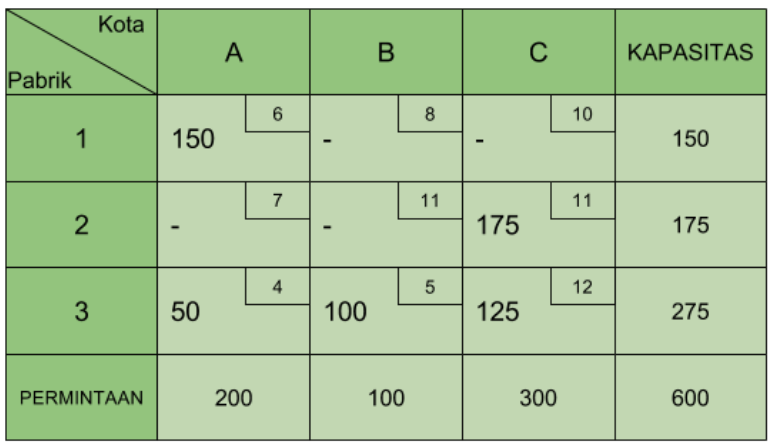

5. Lakukan evaluasi sel kosong untuk ketiga kalinya $1-C=10-12+4-6=-4^{*}$

Teknik Optimasi 
$1-B=8-5+4-6=1$

$2-A=7-11+12-4=4$

$2-B=11-5+12-11=7$

Masih terdapat nilai negatif, maka dipilih negatif terbesar yaitu -4 pada pengiriman dari pabrik 1 ke kota C.

6. Pilih sel nilai negatif terbesar

Setelah dipilih perhitungan biaya yang menghasilkan angka negatif terbesar, pilih sel dengan unit terkecil pada lompatan yang bernilai negatif, dimana dalam hal ini adalah 125. Tambahkan unit terkecil tersebut ke lompatan yang bernilai positif, dan kurangkan ke lompatan yang bernilai negatif. Sehingga didapatkan :

\begin{tabular}{|c|c|c|c|c|c|c|c|}
\hline \multirow[t]{2}{*}{ Kota } & \multicolumn{2}{|c|}{ A } & \multicolumn{2}{|c|}{ B } & \multicolumn{2}{|c|}{ C } & KAPASITAS \\
\hline & \multicolumn{2}{|l|}{25} & - & 8 & 125 & 10 & 150 \\
\hline 2 & - & 7 & - & 11 & 175 & 11 & 175 \\
\hline 3 & 175 & 4 & 100 & 5 & - & 12 & 275 \\
\hline PERMINTAAN & 20 & & & & 30 & & 600 \\
\hline
\end{tabular}

7. Lakukan evaluasi sel kosong untuk keempat kalinya. $1-B=8-5+4-6=1$

Teknik Optimasi 
$2-A=7-11+10-6=0$

$2-B=11-5+4-6+10-11=3$

$3-\mathrm{C}=12-4+6-10=4$

Tidak terdapat nilai negatif pada evaluasi sel kosong, sehingga dapat dikatakan tabel sudah optimal.

\section{Biaya :}

Pabrik 1 ke kota A : $25 \times \$ 6=\$ 150$

Pabrik 1 ke kota $C: 125 \times \$ 10=\$ 1.250$

Pabrik 2 ke kota $C: 175 \times \$ 11=\$ 1.925$

Pabrik 3 ke kota $A$ : $175 \times \$ 4=\$ 700$

Pabrik 1 ke kota B : $100 \times \$ 5=\$ 500$

Total biaya $=\$ 150+\$ 1.250+\$ 1.925+\$ 700+\$ 500$

Total biaya $=\$ 4.525$

Jadi, total biaya transportasi minimum yang dihasilkan dengan menggunakan metode akhir Stepping Stone adalah \$ 4.525 dengan pendistribusian dari pabrik 1 ke kota A sebesar 25 unit dan ke kota $C$ sebanyak 125 unit, dari pabrik 2 ke kota $C$ sebanyak 175 unit, dari pabrik 3 ke kota A dan kota B masing-masing sebesar 175 dan 100 unit.

\section{Metode MOD (Modified Distribution Method)}

Teknik Optimasi 
Metode transportasi MODI (Modified Distribution Method) adalah salah satu metode transportasi untuk mencari solusi akhir (Terminal Solution). Metode MODI mirip dengan metode Stepping Stone karena keduanya sama-sama mencari solusi akhir dari model transportasi agar mendapatkan biaya minimum.

Sehingga, jika persoalan transportasi yang sama baik dikerjakan dengan metode MODI mapun metode Stepping Stone hasil akhirnya akan tetap sama.Yang membedakan hanyalah cara pengerjaannya.Perlu diketahui, sebelum dapat mencari solusi akhir (biaya minimum) baik dalam metode transportasi MODI maupun Stepping Stone, diperlukan dicari atau dihitung terlebih dahulu solusi awal (initial solution nya).

\section{Langkah Pengerjaan}

1. Memberikan angka untuk masing-masing summber dan tujuan transportasi, dengan ketentuan sebagai berikut : Angka untuk sumber yang diletakan pada baris pertama tabel transportasi adalah 0 .

$\rightarrow$ Pemberian angka bergantung kepada sel yang sudah terisi pada solusi awal, sementara sel yang belum terisi (sel yang diberi tanda strip), dapat diabaikan.

$\rightarrow$ Jumlah dari angka yang diberikan pada suatu sumber dan tujuan harus sama dengan biaya yang ditimbulkan dari pendistribusian sumber ke tujuan tersebut.

Teknik Optimasi 
2. Melakukan pengujian terhadap sel yang belum terisi (uji sel kosong) dengan cara mengurangi biaya pada sel kosong tersebut dengan angka yang sudah diberikan kepada sumber dan tujuan dari sel tersebut.

3. Jika hasil dari uji sel kosong ada yang memberikan angka negatif, maka solusi MODI yang dikerjakan dianggap belum optimal dan akan dipilih hasil uji sel kosong yang memberikan angka negatif terbesar.

4. Pada sel kosong yang memberikan angka negatif terbeasr tersebut, akan dilakukan pendekatan metode SteppingStone, yaitu dengan :

$\rightarrow$ Mengamati lompatan yang dapat dilakukan pada tabel kosong tersebut dan memilih unit terkecil pada lompatan yang bernilai negatif, dan menambahkan unit tersebut pada lompatan yang bernilai positif, serta mengurangkan unit tersebut pada lompatan yang bernilai negatif.

5. Membuat tabel transportasi baru yang sudah disesuaikan, dan mengulangi langkah 2 dan 3, hingga tidak ditemukan angka negatif pada pengujian sel kosong. 
6. Jika sudah tidak ada angka negatif, maka tabel transportasi dianggap sudah optimal dan sudah memberikan biaya minimum.

7. Menghitung biaya transportasi yang dihasilkan dengan cara menjumlahkan hasil kali dari jumlah unit dan biaya pada masing-masing sel.

\section{Contoh Soal}

Dounkey Corp. sedang merencanakan untuk mengalokasikan produk yang dihasilkan ke kota A, B, dan C. Berikut tabel transportasi yang sudah disusun oleh manajer Dounkey Corp. (Biaya dalam \$, permintaan dan kapasitas dalam unit).

Tabel transportasi Dounkey Corp.

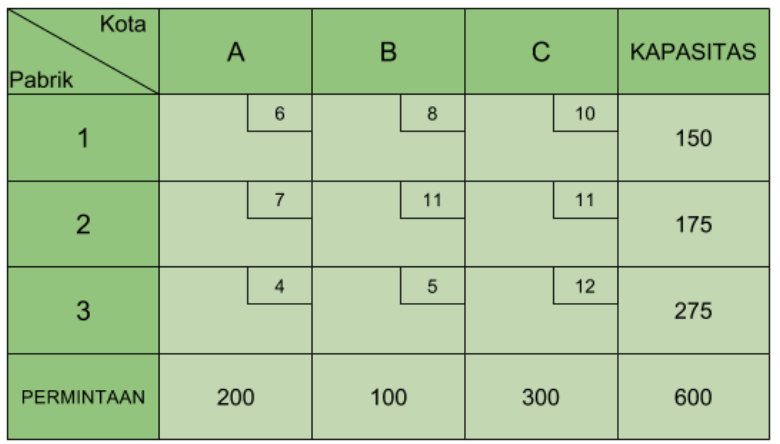

\section{Penyelesaian:}

Karena metode MODI merupakan metode untuk mencari solusi akhir (Terminal solution), maka perlu dicari solusi awalnya terlebih dahulu. Pada artikel sebelumnya 
sudah dibahas tentang metode VAM untuk mencari solusi awal. Sehingga didapatkan tabel transportasinya sebagai berikut :

\begin{tabular}{|c|c|c|c|c|c|c|c|}
\hline \multirow{2}{*}{$\begin{array}{r}\text { Pabrik } \\
1\end{array}$} & \multicolumn{2}{|l|}{ A } & \multicolumn{2}{|c|}{ B } & \multicolumn{2}{|c|}{ C } & KAPASITAS \\
\hline & - & 6 & - & 8 & 150 & 10 & 150 \\
\hline 2 & 175 & 7 & - & 11 & - & 11 & 175 \\
\hline 3 & 25 & 4 & 100 & 5 & 150 & 12 & 275 \\
\hline PERMINTAAN & 200 & & & & & & 600 \\
\hline
\end{tabular}

\section{Langkah Pengerjaan}

1. Memberikan angka untuk masing-masing sumber dan tujuan transportasi.

Rumus : (lihat kotak yang sudah terisi) dimana biaya pada sel tersebut adalah total penjumlahan dari nilai dari baris dan kolomnya. Jadi :

Pabrik 1 Kota $C: 0+C=10 \rightarrow C=10$

Pabrik 3 Kota $C: P 3+10=12 \rightarrow P 3=2$

Pabrik 3 Kota $B: 2+B=5 \rightarrow B=3$

Pabrik 3 Kota $A: 2+A=4 \rightarrow A=2$

Pabrik 2 Kota $\mathrm{A}: \mathrm{P} 2+2=7 \rightarrow \mathrm{P} 2=5$ 


\begin{tabular}{|c|c|c|c|c|c|c|c|}
\hline \multirow{2}{*}{ Pabrik } & \multicolumn{2}{|c|}{$A=2$} & \multicolumn{2}{|c|}{$\mathbf{B}=3$} & \multicolumn{2}{|c|}{$\mathbf{C}=10$} & KAPASITAS \\
\hline & - & 6 & - & 8 & 150 & 10 & 150 \\
\hline $2=5$ & 175 & 7 & - & 11 & - & 11 & 175 \\
\hline $3=2$ & 25 & 4 & 100 & 5 & 150 & 12 & 275 \\
\hline PERMINTAAN & & & & & & & 600 \\
\hline
\end{tabular}

2. Melakukan evaluasi sel kosong

$1-A=6-0-2=4$

$1-B=8-0-3=5$

$2-B=11-5-3=3$

$2-C=11-10-5=-4 *$

Masih terdapat nilai yang negatif, maka dipilih negatif terbesar pada pendistribusian yaitu pada pendistribusian dari pabrik 2 ke kota $\mathrm{C}$.

Untuk cara melakukan evaluasi sel kosong, caranya sama seperti metode Stepping Stone yang sudah dibahas di atas.

3. Alokasi

Alokasikan nilai unit yang baru dengan menambahkan dan mengurangkan sejumlah unit terkecil dari sel yang bertanda negatif, dalam hal ini unitnya adalah 150, 
setelah itu ulangi kembali dari langkah 1 , sehingga tabel yang baru adalah :

\begin{tabular}{|c|c|c|c|c|c|c|c|}
\hline \multirow{2}{*}{$\begin{array}{l}\text { Pabrik } \\
1=0\end{array}$} & \multicolumn{2}{|c|}{$A=6$} & \multicolumn{2}{|c|}{$B=7$} & \multicolumn{2}{|c|}{$\mathbf{C}=10$} & KAPASITAS \\
\hline & - & 6 & - & 8 & 150 & 10 & 150 \\
\hline $2=1$ & 25 & 7 & - & 11 & 150 & 11 & 175 \\
\hline $3=-2$ & 175 & 4 & 100 & 5 & - & 12 & 275 \\
\hline PERMINTAAN & 20 & & 1 & & 30 & & 600 \\
\hline
\end{tabular}

4. Melakukan evaluasi sel kosong

$1-A=6-0-6=0$

$1-B=8-0-7=1$

$2-B=11-1-7=3$

$3-C=12-(-2)-10=4$

Karena tidak ada nilai negatif pada hasil evaluasi sel kosong, sehingga dapat dikatakan tabel sudah optimal.

5. Biaya :

Pabrik 1 ke kota $C: 150 \times \$ 10=\$ 1.500$

Pabrik 2 ke kota A : $25 \times \$ 7=\$ 175$

Pabrik 2 ke kota $C: 150 \times \$ 11=\$ 1.650$

Pabrik 3 ke kota A : 175 x $\$ 4=\$ 700$

Pabrik 3 ke kota B : $100 \times \$ 5=\$ 500$

Total biaya $=\$ 1.500+\$ 175+\$ 1.650+\$ 700+\$ 500$

Teknik Optimasi 


$$
=\$ 4.525
$$

Jadi, total biaya minimum yang dihasilkan dengan menggunakan metode akhir MODI adalah \$4.525 dengan alokasi dari pabrik 1 ke kota $C$ sebanyak 150 unit, pabrik 2 ke kota A dan C sebanyak 25 dan 150 unit, dari pabrik 3 ke kota A sebanyak 175 unit dan ke kota B sebanyak 100 unit.

\section{Metode Vogel's Approximation Method (VAM)}

Metode transportasi VAM (Vogel's Approximation Method) adalah salah satu metode dalam transportasi untuk mencari solusi awal (Initial Solution).

Perbedaan antara metode VAM dengan 2 metode transportasi lainnya adalah dalam metode VAM, distribusi yang dilakukan biasanya sudah mendekati biaya minimum. Sehingga, biasanya hanya diperlukan satu kali perhitungan solusi akhir (Terminal Solution).

\section{Langkah Pengerjaan}

1. Hitung selisih antara dua biaya terkecil dari setiap baris dan kolom. Dinamakan dengan biaya pinalti atau opportunity cost.

2. Pilih baris atau kolom dengan biaya pinalti terbesar. Jika biaya pinalti pada baris atau kolom adalah sama, pilih 
biaya pinalti yang mempunyai nilai biaya transportasi paling rendah.

3. Dari sel yang sudah dipilih, alokasikan jumlah barang sejumlah dengan nilai maksimum dari kapasitas maupun permintaan kolom atau baris.

4. Ulangi langkah diatas dengan menghilangkan barus atau kolom yang sudah terpenuhi, hingga seluruh permintaan dan kapasitas terpenuhi.

\section{Contoh Soal}

Dounkey Corp. sedang merencanakan untuk mengalokasikan produk yang dihasilkan ke kota A, B, dan C. Berikut tabel transportasi yang sudah disusun oleh manajer Dounkey Corp. (Biaya dalam \$, permintaan dan kapasitas dalam unit).

Tabel transportasi Dounkey Corp.

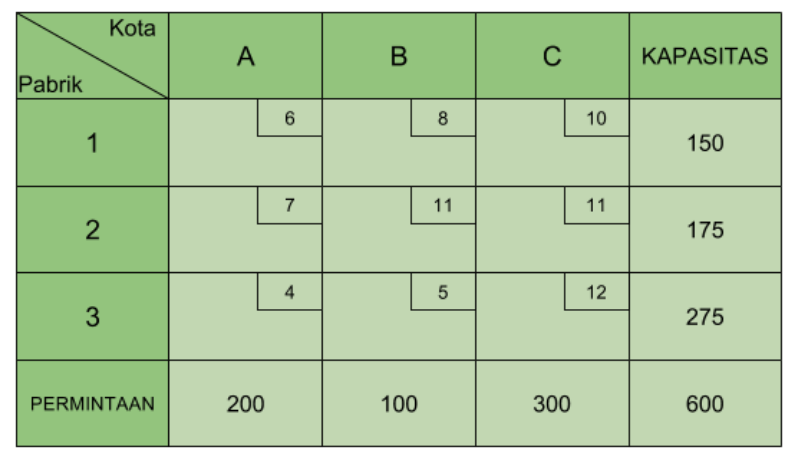

Teknik Optimasi 


\section{Penyelesaian:}

Tahap Pertama

1. Menghitung biaya pinalti (opportunity cost) dari masing-masing kolom dan baris. Biaya pinalti dihitung dengan mengurangi 2 biaya terkecil pada masing-masing baris atau kolom.

2. Memilih 1 biaya pinalti yang paling besar dari baris atau kolom.

3. Alokasikan sebanyak mungkin ke sel dengan biaya termurah, sesuai dengan kapasitas dan permintaan.

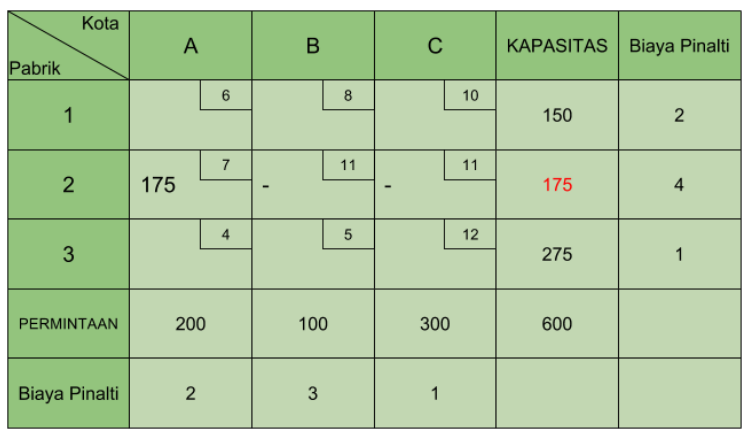

4. Dari hasil perhitungan, diketahui bahwa permintaan dari kota A telah dipenuhi sebanyak 175 unit dari kapasitas pabrik 2.

5. Karena kapasitas pabrik 2 telah habis, sehingga baris pabrik 2 dapat diabaikan pada perhitungan biaya pinalti berikutnya. 


\section{Tahap Kedua}

1. Menghitung kembali masing-masing biaya pinalti dengan mengabaikan baris dari pabrik 2 .

2. Memilih 1 biaya pinalti yang paling besar dari baris atau kolom.

3. Alokasikan barang sebanyak mungkin ke sel dengan biaya termurah sesuai dengan kapasitas dan permintaan.

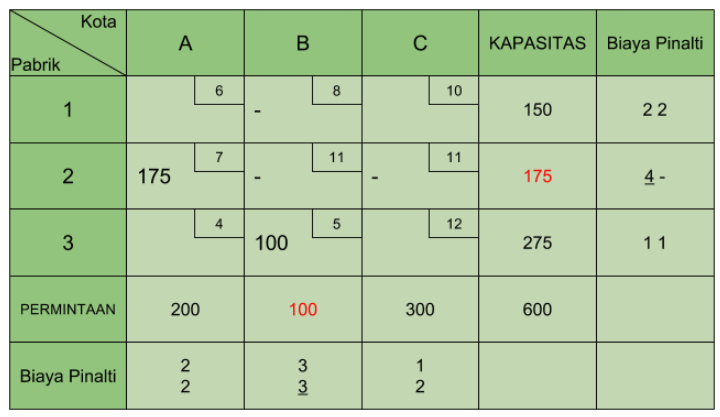

4. Dari hasil perhitungan, diketahui bahwa permintaan kota B telah terpenuhi yaitu sebesar 100 unit, dan kapasitas dari pabrik 3 sudah digunakan sebanyak 100.

5. Kolom kota B yang telah terpenuhi permintaannya dapat diabaikan pada perhitungan biaya pinalti berikutnya.

\section{Tahap Ketiga}

1. Menghitung kembali masing-masing biaya pinalti dengan mengabaikan kolom B dan lanjutkan seperti langkah-langkah sebelumnya. 


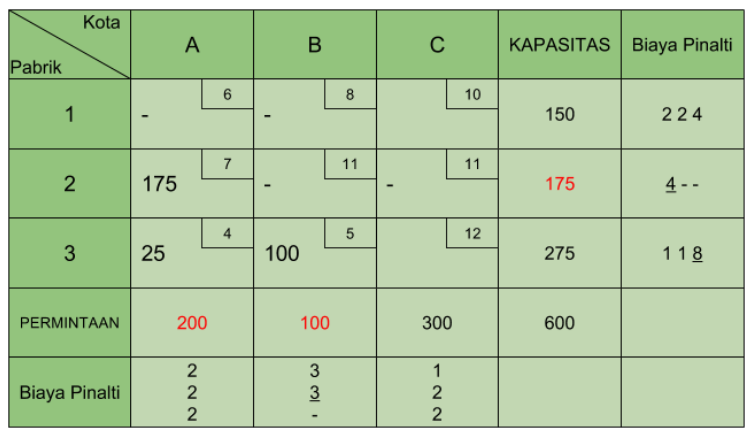

2. Dengan demikian, permintaan di kota $A$ telah terpenuhi seluruhnya sebesar 200 unit, begitu pula dengan permintaan kota B yang telah terpenuhi seluruhnya sebanyak 100 unit.

3. Sehingga, sisa kapasitas yang belum terpenuhi adalah dari pabrik 1 sebesar 150 unit dan dari pabrik 3 juga sebesar 150 unit.

4. Sisa permintaan yang belum terpenuhi dari kota $C$ sebesar 300 unit, sehingga kekurangan di kota $\mathrm{C}$ akan dipenuhi oleh sisa kapasitas di pabrik 1 dan 3. Sehingga didapatkan: 


\begin{tabular}{|c|c|c|c|c|c|c|c|}
\hline Kota & \multicolumn{2}{|l|}{ A } & \multicolumn{2}{|c|}{ B } & \multicolumn{2}{|c|}{ C } & KAPASITAS \\
\hline 1 & - & & - & 8 & 150 & 10 & 150 \\
\hline 2 & 175 & & - & 11 & - & 11 & 175 \\
\hline 3 & 25 & & 100 & 5 & 150 & 12 & 275 \\
\hline PERMINTAAN & 200 & & $1 c$ & & 3 & & 600 \\
\hline
\end{tabular}

\section{Tahap Keempat}

\section{Menghitung biaya transportasinya.}

Pabrik 1 ke kota $C: 150$ unit $x \$ 10=\$ 1.500$

Pabrik 2 ke kota A : 175 unit $x \$ 7=\$ 1.225$

Pabrik 3 ke kota $A$ : 25 unit $x \$ 4=\$ 100$

Pabrik 3 ke kota $B: 100$ unit $x \$ 5=\$ 500$

Pabrik 3 ke kota $C$ : 150 unit $x \$ 12=\$ 1.800$

Total biaya $=\$ 1.500+\$ 1.225+\$ 100+\$ 500+\$ 1.800$

Total biaya $=\$ 5.125$

Total biaya transportasi yang didapat dalam metode VAM (Vogel's Approximation Method) bukanlah total biaya minimum. Karena metode VAM merupakan solusi awal (Initial Solution), sehingga diperlukan perhitungan lebih lanjut dengan 
solusi akhir (Terminal Solution) berupaMetode MODI (Modified Distribution Method).

\section{E. Latihan Soal}

1. Diketahui:

Tabel Transportasi sebagai berikut :

\begin{tabular}{|c|l|l|l|l|l|}
\hline \multicolumn{2}{|c|}{$\begin{array}{c}\text { Sumber } \\
\text { Tujuan }\end{array}$} & \multicolumn{2}{|c|}{ Tujuan Pemasaran } & Kapasitas \\
\cline { 2 - 5 } & Crb & Bdg & Skb & (Supply) \\
\hline \multirow{3}{*}{ Sumber } & Jkt & & & & 56 \\
\cline { 2 - 5 } & Bks & & & & 82 \\
\cline { 2 - 5 } & Tgr & & & & 77 \\
\hline \multicolumn{2}{|c|}{ Permintaan } & 102 & 72 & 41 & 215 \\
\hline
\end{tabular}

Ditanyakan total biaya transportasi dengan penentuan pemecahan optimal (solusi optimal) menggunakan:
a) Metode Stpping Stone)
b) Metode Modi
c) Metode VAM

Teknik Optimasi 
2. Diketahui:

Suatu perusahaan yang mempunyai 3 buah pabrik di $W, H$, P. Perusahaan menghadapi masalah alokasi hasil produksinya dari pabrik-pabrik tersebut ke Gudang-gudang penjualan $A, B, C$.

Teknik Optimasi 
Tabel Kapasitas Pabrik

\begin{tabular}{|l|l|}
\hline Pabrik & $\begin{array}{l}\text { Kapasitas produksi tiap } \\
\text { bulan }\end{array}$ \\
\hline W & 90 ton \\
\hline H & 60 ton \\
\hline P & 50 ton \\
\hline Jumlah & 200 ton \\
\hline
\end{tabular}

Tabel Kebutuhan Gudang

\begin{tabular}{|l|l|}
\hline Gudang & Kebutuhan tiap bulan \\
\hline A & 50 ton \\
\hline B & 110 ton \\
\hline C & 40 ton \\
\hline Jumlah & 200 ton \\
\hline
\end{tabular}

Ditanyakan total biaya transportasi dengan penentuan pemecahan optimal (solusi optimal) menggunakan:
a. Metode Stpping Stone)
b. Metode Modi
c. Metode VAM

Teknik Optimasi 


\section{A. Pendahuluan}

Model penugasan merupakan bentuk khusus metode transportasi. Kasus yang dapat diselesaikan menggunakan model penugasan akan lebih mudah diselesaikan menggunakan metode penyelesaian yang ada pada model penugasan dibandingkan jika menggunakan metode transportasi. Seperti yang telah ditunjukkan namanya, kasus yang dapat diselesaikan dengan metode penugasan adalah kasus-kasus penugasan, seperti penugasan beberapa karyawan untuk menyelesaikan beberapa pekerjaan, atau beberapa mesin untuk menyelesaikan beberapa pekerjaan.

Tujuan optimasi meminimumkan biaya dan memaksimumkan biaya dari penugasan

\section{B. Masalah Maksimisasi}

\section{Langkah-langkah:}

1. Menentukan nilai terbesar dari setiap baris, lalu mengurangkan semua nilai pada setiap baris dari nilai terbesarnya. 
2. Jika seriap kolom telah mempunyai nilai nol maka lanjut ke langkah ke 3, jika belum ada dilakukan penentuan nilai terkecil disetiap kolom yang belom mempunyai nilai nol, kemudian setiap nilai pada kolom tersebut dikurangkan dengan nilai terkecilnya.

3. Menentukan apakah terdapat $\mathrm{n}$ elemen nol dimana tidak ada nilai nol yang berada pada baris/kolom yang sama, dimana $\mathrm{n}$ adalah jumlah kolom/baris. Jika ada, maka tabel telah optimal, jika tidak dilanjutkan ke langkah 4.

4. Melakukan penutupan semua nilai nol dengan menggunakan garis vertikal/horizontal seminimal mungkin.

5. Menentukan nilai terkecil dari nilai-nilai yang tidak tertutup garis. Lalu semua nilai yang tidak tertutup garis dikurangkan nilai terkecil tersebut.

6. Kembali ke langkah 3

\section{Contoh Soal}

Seorang manager pemasaran ingin menempatkan empat orang salesmannya di empat daerah pemasaran produknya. Penempatan salesman tersebut didasarkan pada perolehan nilai keuntungan yang diperkirakan akan diperoleh oleh setiap salesman di setiap daerah pemasaran berdasarkan prestasi kerja mereka saat ini dan pengenalan terhadap masing-masing daerah pemasaran tersebut. 
Bila data perolehan keuntungan dari setiap salesman di setiap daerah pemasaran seperti yang tersaji pada Tabel 1, tentukan penugasan salesman yang harus dibuat oleh sang manager agar keuntungan yang diperoleh maksimal.

Tabel 1 : Data

\begin{tabular}{|l|c|c|c|c|}
\hline $\begin{array}{l}\text { Lokasi / } \\
\text { Sales }\end{array}$ & $\begin{array}{c}\text { Lokasi } \\
1\end{array}$ & $\begin{array}{c}\text { Lokasi } \\
2\end{array}$ & $\begin{array}{c}\text { Lokasi } \\
3\end{array}$ & $\begin{array}{c}\text { Lokasi } \\
4\end{array}$ \\
\hline Sales 1 & 1000 & 900 & 1100 & 900 \\
\hline Sales 2 & 1100 & 1000 & 950 & 950 \\
\hline Sales 3 & 1050 & 950 & 900 & 1050 \\
\hline Sales 4 & 1150 & 1000 & 950 & 1000 \\
\hline
\end{tabular}

Tujuan yang ingin dicapai dalam penugasan salesman di atas adalah diperolehnya keuntungan yang maksimal, sehingga masalah ini tergolong dalam masalah maksimisasi.

\section{Penyelesaian:}

1. Menentukan nilai terbesar dari setiap baris dengan hasil sebagai berikut :

$\begin{array}{ll}\text { Baris I } & : 1100 \\ \text { Baris II } & : 1100 \\ \text { Baris III } & : 1050 \\ \text { Baris IV } & : 1150\end{array}$

Hal ini berarti bahwa nilai-nilai keuntungan pada baris I dikurangkan dari 1100, baris II dikurangkan dari 1100, baris III 
dikurangkan 1050 dan baris IV dikurangkan dari 1150. Hasil perhitungan langkah pertama ini dapat dilihat pada Tabel 2

Tabel 2: Hasil Perbaikan Pertama

\begin{tabular}{|l|c|c|c|c|}
\hline $\begin{array}{l}\text { Lokasi / } \\
\text { Sales }\end{array}$ & $\begin{array}{c}\text { Lokasi } \\
1\end{array}$ & $\begin{array}{c}\text { Lokasi } \\
2\end{array}$ & $\begin{array}{c}\text { Lokasi } \\
3\end{array}$ & $\begin{array}{c}\text { Lokasi } \\
4\end{array}$ \\
\hline Sales 1 & 100 & 200 & 0 & 200 \\
\hline Sales 2 & 0 & 100 & 150 & 150 \\
\hline Sales 3 & 0 & 100 & 150 & 0 \\
\hline Sales 4 & 0 & 150 & 200 & 150 \\
\hline
\end{tabular}

2. Memeriksa apakah setiap kolom telah mempunyai nilai nol. Ternyata pada Tabel 2 terlihat bahwa kolom II belum mempunyai nilai nol, sehingga perlu ditentukan nilai tentukan nilai terkecil dari kolom tersebut, yaitu 100. Setiap nilai pada kolom II dikurangkan dengan 100, sehingga diperoleh hasil seperti pada Tabel 3.

Tabel 3: Tabel Akhir (Optimum)

\begin{tabular}{|l|c|c|c|c|}
\hline $\begin{array}{l}\text { Lokasi / } \\
\text { Sales }\end{array}$ & $\begin{array}{c}\text { Lokasi } \\
1\end{array}$ & $\begin{array}{c}\text { Lokasi } \\
2\end{array}$ & $\begin{array}{c}\text { Lokasi } \\
3\end{array}$ & $\begin{array}{c}\text { Lokasi } \\
4\end{array}$ \\
\hline Sales 1 & 100 & 100 & 0 & 200 \\
\hline Sales 2 & 0 & 0 & 150 & 150 \\
\hline Sales 3 & 0 & 0 & 150 & 0 \\
\hline Sales 4 & 0 & 50 & 200 & 150 \\
\hline
\end{tabular}


3. Sekarang lihat apakah ada empat nilai nol pada Tabel 3 dimana keempat-empatnya berada pada baris dan kolom yang berbeda. Ternyata ada, sehingga Tabel 3 dapat dinyatakan sebagai tabel optimal.

4. Menentukan penugasan salesman ke daerah pemasaran berdasarkan pada nilai-nilai nol tadi. Dimulai dengan jumlah nilai nol satu, yaitu :

1. Baris I dan IV, yang berarti salesman 1 ditempatkan di daerah pemasaran 3, salesman 4 ditempatkan di daerah pemasaran 1.

2. Baris II terdapat dua nilai nol, tetapi karena daerah pemasran 1 telah diberikan kepada salesman 4, maka salesman 2 ditempatkan di daerah pemasaran 2, dan yang terakhir salesman 3 ditempatkan di daerah pemasaran 4.

5. Berdasarkan penugasan yang dibuat di atas maka nilai keuntungan yang akan diperoleh adalah sebesar $1100+1000$ $+1050+1150=4300$

\section{Masalah-Masalah Penugasan Tambahan Minimisasi}

Langkah-langkah penyelesaian dengan metoda Hungarian untuk masalah minimisasi adalah sebagai berikut : 
1. Menentukan nilai terkecil dari setiap baris, lalu mengurangkan semua nilai dalam baris tersebut dengan nilai terkecilnya.

2. Memeriksa apakah setiap kolom telah mempunyai nilai nol. Bila sudah dilanjutkan ke langkah 3,bila belum, dilakukan penentuan nilai terkecil dari setiap kolom yang belum mempunyai nilai nol, kemudian setiap nilai pada kolom tersebut dikurangkan dengan nilai terkecilnya.

3. Menentukan apakah terdapat $\mathrm{n}$ elemen nol dimana tidak ada nilai nol yang berada pada baris/kolom yang sama, dimana $\mathrm{n}$ adalah jumlah kolom/baris. Jika ada, maka tabel telah optimal, jika tidak, dilanjutkan ke langkah 4.

4. Melakukan penutupan semua nilai nol dengan menggunakan garis vertikal/horizontal seminimal mungkin.

5. Menentukan nilai terkecil dari nilai-nilai yang tidak tertutup garis. Lalu semua nilai yang tidak tertutup garis dikurangkan dengan nilai terkecil tersebut.

6. Kembali ke langkah 3

\section{Contoh Soal}

Seorang pelatih renang ingin membentuk tim renang yang tangguh untuk terjun di nomor $400 \mathrm{~m}$ estafet gaya ganti pada suatu pertandingan tingkat nasional. Ada empat perenang di 
bawah asuhannya, yang merupakan perenang terbaiknya yang menguasai dengan baik keempat gaya yang dipertandingkan. Pelatih ingin melakukan penugasan satu perenang pada satu gaya berdasarkan data waktu terbaik mereka untuk tiap gaya nomor $100 \mathrm{~m}$ yang tersaji pada tabel 2 , dengan bantuan metode Hungarian

Tabel 1 : Data Perolehan Waktu (dalam detik)

\begin{tabular}{|c|c|c|c|c|}
\hline $\begin{array}{c}\text { Perenang/ } \\
\text { Gaya }\end{array}$ & Budi & Giri & Koko & Fajar \\
\hline $\begin{array}{c}\text { Kupu-Kup } \\
\text { u }\end{array}$ & 52,4 & 48,3 & 55,6 & 49,5 \\
\hline Dada & 55,4 & 58,2 & 59,1 & 57,3 \\
\hline Punggung & 62,7 & 62,5 & 60,9 & 63,2 \\
\hline Bebas & 47,7 & 49,1 & 53,5 & 52,1 \\
\hline
\end{tabular}

\section{Penyelesaian:}

Pada suatu pertandingan renang selau diinginkan waktu tercepat yang mungkin dapat dilakukan, sehingga masalah ini masuk ke dalam masalah minimisasi.

Langkah-langkah:

1. Menentukan nilai terkecil dari setiap baris. Hasil penentuan nilai terkecil tersebut adalah sebagai berikut :

Baris I : 48.3

Baris II : 55.4

Teknik Optimasi 
Baris III : : 60.9

Baris IV : : 47.7

Sehingga setiap nilai pada baris I dikurangkan dengan 48.3 setiap nilai pada baris II dikurangkan dengan 55.4, setiap nilai pada baris II dikurangkan dengan 60.9 dan setiap baris IV dikurangkan dengan 47.7. Hasil perhitungan langkah pertama ini dapat dilihat pada Tabel 2.

Tabel 2: Data Perbaikan Pertama

\begin{tabular}{|c|c|c|c|c|}
\hline $\begin{array}{c}\text { Perenang/ } \\
\text { Gaya }\end{array}$ & Budi & Giri & Koko & Fajar \\
\hline $\begin{array}{c}\text { Kupu-Kup } \\
\text { u }\end{array}$ & 4.1 & 0 & 7.3 & 1.2 \\
\hline Dada & 0 & 2.8 & 3.7 & 1.9 \\
\hline Punggung & 1.8 & 1.6 & 0 & 2.3 \\
\hline Bebas & 0 & 1.4 & 5.8 & 4.4 \\
\hline
\end{tabular}

2. Memeriksa apakah setiap kolom telah mempunyai nilai nol. Ternyata pada kolom IV belum terdapat nilai nol, sehingga dilakukan penentuan nilai terkecil dari kolom ini, yaitu 1.2, kemudian setiap nilai pada kolom IV ini dikurangkan dengan 1.2, sehingga diperoleh nilai seperti yang tersaji pada Tabel 3 
Tabel 3 : Data Perbaikan Kedua

\begin{tabular}{|c|c|c|c|c|}
\hline $\begin{array}{c}\text { Perenang/ } \\
\text { Gaya }\end{array}$ & Budi & Giri & Koko & Fajar \\
\hline $\begin{array}{c}\text { Kupu-Kup } \\
\text { u }\end{array}$ & 4.1 & 0 & 7.3 & 0 \\
\hline Dada & 0 & 2.8 & 3.7 & 0.7 \\
\hline Punggung & 1.8 & 1.6 & 0 & 1,1 \\
\hline Bebas & 0 & 1.4 & 5.8 & 3.2 \\
\hline
\end{tabular}

3. Memeriksa apakah telah terdapat suatu penugasan yang layak. Bila diperhatikan akan ditemui sejumlah 5 nilai nol pada tabel 3. Tetapi dari kelima nilai nol tersebut, tidak ada empat nilai nol yang keempat-empatnya terdapat pada baris dan kolom yang berbeda. Misalnya kita ambil nilai pada kotak (1.2), (2.1), (3.3) dan (4.1), kita masih menemukan adanya dua nilai nol yang berada pada kolom yang sama yaoti nilai nol pada kotak (2.1) dan (4.1). Hal yang sama juga akan terjadi pada kemungkinan-kemungkinan yang lainya. Ini menandakan bahwa tabel belum optimal, sehingga perlu dilakukan langkah-langkah selanjutnya guna mendapatkan tabel yang optimal.

4. Menutup seluruh nilai nol dengan garis vertikal dan horizontal seminimal mungkin, seperti yang terlihat pada tabel 4 . 
Tabel 4 : Hasil Perbaikan Ketiga

\begin{tabular}{|c|c|c|c|c|}
\hline $\begin{array}{c}\text { Perenang/ } \\
\text { Gaya }\end{array}$ & Budi & Giri & Koko & Fajar \\
\hline $\begin{array}{c}\text { Kupu-Kup } \\
\text { u }\end{array}$ & \multicolumn{4}{|l}{} \\
\hline Dada & 2,8 & 3,7 & 0,7 \\
\hline Punggung & \multicolumn{4}{|c|}{} \\
\hline Bebas & 1,4 & 5,8 & 3,2 \\
\hline
\end{tabular}

Pada Tabel 4 terlihat bahwa jumlah garis yang menutup nilai nol tersebut ada tiga dan ini merupakan jumlah yang minimal, karena tidak mungkin menutup semua nilai nol dengan hanya dua garis vertikal/horizontal.

5. Setelah seluruh nilai nol tertutup oleh garis vertikal/horizontal, maka dilakukan penentuan nilai terkecil dari nilai-nilai yang tidak tertutup garis. Bila diperhatikan Tabel 4, maka nilai terkecil yang dimaksud adalah 0,7. Selanjutnya kita kurangkan setiap nilai yang tidak tertutup garis dengan 0,7. Langkah ini menghasilkan nilai seperti yang tersaji pada Tabel 5 . 
Tabel 5 : Tabel Akhir (Optimal)

\begin{tabular}{|c|c|c|c|c|}
\hline $\begin{array}{c}\text { Perenang/ } \\
\text { Gaya }\end{array}$ & Budi & Giri & Koko & Fajar \\
\hline $\begin{array}{c}\text { Kupu-Kup } \\
\text { u }\end{array}$ & \multicolumn{4}{|l|}{} \\
\hline Dada & 2,1 & 3,0 & 0 \\
\hline Punggung & \multicolumn{4}{|l|}{} \\
\hline Bebas & 0,7 & 5,1 & 2,5 \\
\hline
\end{tabular}

6. Lakukan pemeriksaan apakah telah terdapat suatu penugasan yang layak yang memberikan solusi optimal. Pada Tabel 5 terlihat bahwa terdapat sejumlah empat nilai nol yang keempat-empatnya berada pada baris dan kolom yang berbeda sehingga dapat dikatakan bahwa tabel telah optimal. Dengan telah diperolehnya tabel yang optimal, maka ini diberikan kepada pasangan assigne-assignment pada kotak yang bernilai nol pada tabel optimal.

7. Penentuan penugasan sebaiknya dimulai dari baris yang hanya mengandung satu nilai nol. Pada Tabel 5, baris yang dimaksud adalah baris ke-3 dan ke-4. Hal ini berarti gaya punggung ditugaskan kepada Koko dan gaya bebas kepada Budi. Kemudian untuk baris ke-2, karena Budi telah mendapatkan tugas di gaya bebas, maka gaya dada diberikan kepada Fajar, sedangkan gaya kupu-kupu, pada baris ke-1, diberikan kepada 
Giri. Berdasarkan pada penugasan tersebut, maka perolehan waktu yag diperkirakan pada nomor estafet gaya ganti adalah $48,3+57,3+60,9+47,7=214,2$

\section{Jumlah Pekerjaan tidak sama dengan jumlah karyawan}

Kolom/baris dummy ditambahkan bila jumlah assignee tidak sama dengan assignment, atau terkadang disebut sebagai masalah tak seimbang. Pada kolom/baris dummy ini diberikan nilai keuntungan/kerugian sebesar nol. Sedangkan untuk suatu hubungan assignee dan assignment yang tidak mungkin (boleh) terjadi, untuk hubungan keduanya diberikan nilai keuntungan sebesar $-M$ atau nilai kerugian sebesar $M$. Nilai $M$ ini mewakili bilangan yang sangat besar bila dibandingkan dengan bilangan-bilangan lain yang menunjukkan nilai keuntungan/kerugian lainnya. -M berarti suatu keuntungan yang sangat kecil dan $\mathrm{M}$ berarti kerugian yang sangat besar.

\section{Contoh Soal :}

1. Dounkey Corp. hendak merekrut 4 pekerja untuk menempati 4 posisi jabatan yang kosong. Berikut adalah data mengenai kepuasan pekerja dari posisi yang ada :

\begin{tabular}{|l|l|l|l|l|}
\hline $\begin{array}{l}\text { Pekerjaan/ } \\
\text { Pekerja }\end{array}$ & Accounting & Finance & Marketing & Engineer \\
\hline Batman & 950 & 850 & 750 & 840 \\
\hline Wonder Woman & 985 & 860 & 780 & 820 \\
\hline Flash & 970 & 840 & 770 & 830 \\
\hline Superman & 900 & 870 & 760 & 850 \\
\hline
\end{tabular}

Teknik Optimasi 
Berdasarkan data diatas, bantulah Dounkey.Co untuk menentukan penugasan yang tepat guna agar pekerja mendapat kepuasan maksimum!

\section{Penyelesaian:}

1. Karena tabel penugasan sudah ada berarti bisa langsung lanjut ke langkah 2.

2. Kasus kali ini adalah kasus maksimasi, sehingga setiap baris harus diselisihkan dengan angka terbesar pada baris tersebut. Misalnya pada baris Batman, semua angka pada garis tersebut harus diselisihkan dengan 950. Ingat karena selisih, jadi hasilnya tidak mungkin negatif. Selisihkan juga masing-masing untuk Wonder Woman, Flash, dan Superman. Sehingga tabel penugasannya akan menjadi sebagai berikut :

\begin{tabular}{|l|l|l|l|l|}
\hline $\begin{array}{l}\text { Pekerjaan/ } \\
\text { Pekerja }\end{array}$ & Accounting & $\begin{array}{l}\text { Financ } \\
\mathrm{e}\end{array}$ & Marketing & Engineer \\
\hline Batman & 0 & 100 & 200 & 110 \\
\hline $\begin{array}{l}\text { Wonder } \\
\text { Woman }\end{array}$ & 0 & 125 & 205 & 165 \\
\hline Flash & 0 & 130 & 200 & 140 \\
\hline Superman & 0 & 30 & 140 & 50 \\
\hline
\end{tabular}


3. Pada langkah ke 3, selisihkan angka-angka pada setiap kolom dengan angka terkecil pada masing-masing kolom. Jika pada kolom tersebut terdapat angka nol, tentunya tidak akan terjadi perubahan. Karena angka berapapun jika diselisihkan dengan nol maka hasilnya akan tetap sama.

Misalnya pada kolom Accounting, angkanya tidak akan terjadi perubahan karena semua angka pada kolom tersebut diselisihkan dengan 0 hasilnya akan tetap 0 . Sedangkan pada kolom Finance, semua angka pada kolom tersebut harus diselisihkan dengan 30, yang merupakan angka terkecil.

Lakukan hal yang sama juga pada kolom Marketing dan Engineer, sehingga tabel penugasannya menjadi :

\begin{tabular}{|l|l|l|l|l|}
\hline $\begin{array}{l}\text { Pekerjaan/ } \\
\text { Pekerja }\end{array}$ & Accounting & $\begin{array}{l}\text { Financ } \\
\text { e }\end{array}$ & Marketing & Engineer \\
\hline Batman & 0 & 70 & 60 & 60 \\
\hline $\begin{array}{l}\text { Wonder } \\
\text { Woman }\end{array}$ & 0 & 95 & 65 & 115 \\
\hline Flash & 0 & 100 & 60 & 90 \\
\hline Superman & 0 & 0 & 0 & 0 \\
\hline
\end{tabular}


Maka, dengan ini telah didapatkan angka nol pada setiap baris dan kolom, dan langkah selanjutnya adalah melakukan pengujian.

4. Pengujian dilakukan dengan membuat garis vertikal/horizontal pada angka nol dengan jumlah yang minimal seperti aturan yang telah dijelaskan diatas. Sehingga garisnya menjadi :

\begin{tabular}{|c|c|c|c|c|}
\hline $\begin{array}{l}\text { Pekerjaan/ } \\
\text { Pekerja }\end{array}$ & $\begin{array}{c}\text { Accounting } \\
:\end{array}$ & $\begin{array}{l}\text { Financ } \\
\text { e }\end{array}$ & Marketing & Engineer \\
\hline Batman & 0 & 70 & 60 & 60 \\
\hline $\begin{array}{l}\text { Wonder } \\
\text { Woman }\end{array}$ & 0 & 95 & 65 & 115 \\
\hline Flash & 0 & 100 & 60 & 90 \\
\hline Superman & $\theta \cdots \cdots$ & $\theta \cdots$ & $0 \cdots \cdots$ & $\theta=$ \\
\hline
\end{tabular}

5. Hitunglah jumlah garis yang telah kalian buat. Dimana didapat jumlah garis hanya ada 2 , sedangkan terdapat 4 Teknik Optimasi 
baris/kolom. Karena Jumlah garis $\neq$ Jumlah baris/kolom, maka diperlukan perhitungan lebih lanjut.

6. Lakukan pengoptimalan tabel dengan langkah-langkah dan aturan seperti yang telah dijelaskan diatas.Angka terkecil yang tidak kena garis pada tabel tersebut adalah 60, jadi semua angka yang tidak kena garis harus dikurangi 60, dan angka yang kena garis 2 kali (perpotongan garis) ditambah 60 . Sedangkan angka yang hanya kena garis 1 kali nilainya tetap. Sehingga tabelnya akan menjadi :

\begin{tabular}{|l|l|l|l|l|}
\hline $\begin{array}{l}\text { Pekerjaan/ } \\
\text { Pekerja }\end{array}$ & Accounting & $\begin{array}{l}\text { Financ } \\
\text { e }\end{array}$ & Marketing & Engineer \\
\hline Batman & 0 & 10 & 0 & 110 \\
\hline $\begin{array}{l}\text { Wonder } \\
\text { Woman }\end{array}$ & 0 & 35 & 5 & 55 \\
\hline Flash & 0 & 40 & 0 & 30 \\
\hline Superman & 60 & 0 & 0 & 0 \\
\hline
\end{tabular}

Teknik Optimasi 
Ulangi kembali langkah ke-4 dengan membuat garis untuk menguji apakah tabelnya sudah optimal atau belum. Sehingga garisnya menjadi :

\begin{tabular}{|l|l|l|l|l|}
\hline Pekerjaan/ & Accounting & Financ & Marketing & Engineer \\
& & e & & \\
& & $\vdots$ & & \\
& & $\vdots$ & & \\
& & $\vdots$ & & \\
& & & & \\
& & 1 & & \\
\hline Batman & 0 & $10--$ & 0 & \\
\hline Wonder & 0 & 35 & 5 & 55 \\
Woman & & & & \\
\hline Flash & 0 & 40 & 0 & 30 \\
\hline
\end{tabular}

Teknik Optimasi 


\begin{tabular}{|l|l|l|l|l|}
\hline Superman & 0 & $0---1$ & $0----0$ \\
\hline
\end{tabular}

Jika dilihat jumlah garis = jumlah baris/kolom

Sehingga tabel diatas dikatakan sudah optimal yang menghasilkan kepuasan maksimum (kasus maksimasi). Perlu diingat kembali, jika soalnya adalah kasus minimasi, caranya sama persis seperti langkah diatas, yang membedakan hanyalah pada langkah ke-2, karena pada kasus minimasi diselisihkan dengan angka terkecil.

7. Lakukan penentuan tugas, dengan melihat angka nol pada tabel penugasan. Jika pekerja mendapat nilai nol pada pekerjaan tersebut, menandakan nilai yang optimal. Tabel akhirnya adalah :

\begin{tabular}{|l|l|l|l|l|}
\hline $\begin{array}{l}\text { Pekerjaan/ } \\
\text { Pekerja }\end{array}$ & Accounting & $\begin{array}{l}\text { Financ } \\
\text { e }\end{array}$ & Marketing & Engineer \\
\hline Batman & 0 & 10 & 0 & 110 \\
\hline $\begin{array}{l}\text { Wonder } \\
\text { Woman }\end{array}$ & 0 & 35 & 5 & 55 \\
\hline Flash & 0 & 40 & 0 & 30 \\
\hline Superman & 60 & 0 & 0 & 0 \\
\hline
\end{tabular}

Jadi, Kemungkinan nya adalah sebagai berikut : 
1. Batman bekerja sebagai Marketing

2. Batman bekerja sebagai Engineer

3. WonderWoman bekerja sebagai Accounting

4. Flash bekerja sebagai Accounting

5. Flash bekerja sebagai Marketing

6. Superman bekerja sebagai Finance

7. Superman bekerja sebagai Marketing

8. Superman bekerja sebagai Engineer

Penentuan pekerjaan dilakukan dengan memilih pekerja yang hanya mempunyai 1 kemungkinan terlebih dahulu. Dalam kasus ini adalah Wonder Woman yang hanya mungkin bekerja sebagai Accounting. Ingat!! dalam penugasan 1 pekerjaan hanya dapat diisi oleh 1 pekerja atau sebaliknya. Jadi pekerjaan accounting sudah tidak mungkin diisi oleh para pekerja lain. Karena Accounting sudah tidak mungkin diisi lagi, jadi Flash hanya mungkin bekerja sebagai Marketing. Karena Accounting dan Marketing sudah tidak mungkin diisi lagi, jadi tentunya Batman hanya mungkin bekerja sebagai Engineer. Sama seterusnya dimana Superman hanya mungkin bekerja sebagai Finance.

Kesimpulan :

1. Batman bekerja sebagai Engineer

2. Wonder Woman bekerja sebagai Accounting

3. Flash bekerja sebagai Marketing

4. Superman bekerja sebagai Finance

Dengan tingkat kepuasan maksimum sebesar (lihat dari tabel paling pertama) : 


\begin{tabular}{|l|l|l|}
\hline Pekerja & Pekerjaan & $\begin{array}{l}\text { Tingkat } \\
\text { Kepuasa } \\
\mathbf{n}\end{array}$ \\
\hline Batman & Engineer & 840 \\
\hline $\begin{array}{l}\text { Wonder } \\
\text { Woman }\end{array}$ & Accounting & 985 \\
\hline Flash & Marketing & 770 \\
\hline Superman & Finance & 870 \\
\hline Total & & 3.465 \\
\hline
\end{tabular}

\section{E. Latihan Soal}

1. Sebuah perusahaan kecil memiliki 5 (lima) produk yang berbeda untuk dijual oleh 4(Sales Promotion Girl (SPG) . Berikut adalah tabel penjualan produk oleh setiap oleh SPG:

\begin{tabular}{|c|c|c|c|c|c|c|}
\hline \multicolumn{2}{|c|}{$\begin{array}{c}\text { Penjualan } \\
\text { (Unit) }\end{array}$} & \multicolumn{5}{|c|}{ Produk } \\
\cline { 2 - 7 }$y$ & $\mathrm{~A}$ & 15 & 9 & 12 & 6 & 10 \\
\hline \multirow{3}{*}{ SPG } & $\mathrm{B}$ & 13 & 8 & 14 & 11 & 16 \\
\cline { 2 - 8 } & $\mathrm{C}$ & 7 & 12 & 8 & 10 & 11 \\
\hline
\end{tabular}

Teknik Optimasi 


\begin{tabular}{|l|l|l|l|l|l|l|}
\hline & $\mathrm{D}$ & 14 & 13 & 10 & 9 & 7 \\
\hline
\end{tabular}

Bagaimana cara penugasan untuk tiaptiap SPG yang harus diambil perusahaan untuk memperoleh penjualanmaksimum?

2. Suatu perusahaan kotak hadiah mempunyai empat pekerjaan yang berbeda, yaitu memotong karton,merekatkan kertas warna, memberi hiasan, dan membungkus. Perusahaan kotak hadiah tersebut hanya memiliki empat orang karyawan yaitu Hana, Karin, Helmi, dan Rossy. Upah seorang karyawan untuk masing-masing pekerjaan berbeda-beda seperti berikut:

Tabel Upah Karyawan

\begin{tabular}{|l|l|l|l|l|}
\hline $\begin{array}{l}\text { Tugas/ } \\
\text { Karyawan }\end{array}$ & Hana & Karin & Helmi & Rossy \\
\hline $\begin{array}{l}\text { Memotong } \\
\text { Karton }\end{array}$ & Rp.15.000 & Rp.14.000 & Rp.18.000 & Rp.17.000 \\
\hline $\begin{array}{l}\text { Merekatkan } \\
\text { Kertas Warna }\end{array}$ & Rp.21.000 & Rp.16.000 & Rp.18.000 & Rp.22.000 \\
\hline $\begin{array}{l}\text { Memberi } \\
\text { Hiasan }\end{array}$ & Rp.21.000 & Rp.21.000 & Rp.24.000 & Rp.19.000 \\
\hline Membungkus & Rp.22.000 & Rp.18.000 & Rp.20.000 & Rp.16.000 \\
\hline
\end{tabular}

Teknik Optimasi 
Tentukan biaya minimal yang dikeluarkan perusahaan kotak hadiah tersebut dengan kondisi satu pekerjaan hanya dikerjakan oleh satu karyawan?

3. Sebuah perusahaan memiliki 4 orang karyawan yang harus menyelesaikan 4 pekerjaan yang berbeda. Karena sifat pekerjaan dan juga ketrampilan, karakteristik dari masing masing karyawan, maka biaya yang timbul dari berbagai alternatif penugasan dari ke 4 karyawan tersebut juga berbeda, seperti terlihat dari tabel penugasan berikut ini:

\begin{tabular}{|c|c|c|c|c|}
\hline \multirow{2}{*}{ Karyawan } & \multicolumn{4}{|c|}{ Pekerjaan } \\
\cline { 2 - 5 } & I & II & III & IV \\
\hline A & 15 & 20 & 18 & 22 \\
\hline B & 14 & 16 & 21 & 17 \\
\hline C & 25 & 20 & 23 & 20 \\
\hline D & 17 & 18 & 18 & 16 \\
\hline
\end{tabular}

Tentukan biaya minimal yang dikeluarkan perusahaan agar keempat karyawan itu dapat bekerja dengan tepat?

4. Pada sebuah bengkel tersedia 4 orang mekanik yang harus ditempatkan pada 4 bengkel yang ada ( 1 mekanik untuk 1 bengkel). Pemilik bengkel telahmemperoleh data 
nilai prestasi keempat mekanik pada keempat bengkel sebagai berikut :

\begin{tabular}{|c|c|c|c|c|}
\hline \multirow{2}{*}{$\begin{array}{c}\text { Mekanik } \\
\text { (A) }\end{array}$} & \multicolumn{4}{|c|}{ Bengkel (B) } \\
\cline { 2 - 5 } & B1 & B2 & B3 & B4 \\
\hline A1 & 67 & 76 & 82 & 75 \\
\hline A2 & 80 & 70 & 65 & 77 \\
\hline A3 & 77 & 68 & 70 & 74 \\
\hline A4 & 70 & 73 & 78 & 80 \\
\hline
\end{tabular}

Prestasi mekanik M1 di bengkel B3 adalah 82, prestasi mekanik M1dibengkel B1 adalah 77, dan seterusnya. Bagaimana penugasan terbaiknya yang dapat menghasilkan prestasi mekanik bengkel keseluruhan adalah yang terbesar? 


\section{A. Pendahuluan}

Konsep network ini mula-mula disusun oleh perusahaan jasa konsultan manajemen Boaz, Allen dan Hamilton yang disusun untuk perusahaan pesawat terbang Lockheed. Kebutuhan penyusunan network ini dirasakan karena perlu adanya koordiansi dan pengurutan kegiatan-kegiatan peabrik

Teknik Optimasi 
yang kompleks, yang saling berhubungan dan saling tergantung satu sama lain. Hal ini dilakukan agar perencanaan dan pengawasan semua kegiatan itu dapat dilakukan secara sistematis, sehingga dapat diperoleh efisiensi kerja. Nama prosedur ini disebut PERT (Program Evaluation and Review Technique). Banyak lembaga-lembaga lain yang kemudian juga dapat menerapkan/ menyusun konsep analisa network ini. Akibatnya nama untuk menyebut analisa network ini banyak sekali, meskipun konsepnya hampir sama. Nama yang paling umum dipakai adalah PERT dan CPM (critical pathmethod).

CPM disusun pertama kali oleh Du Pont Company tanpa meniru PERT, tetapi kedua metode itu konsepnya hampir sama. Meskipun konsep kedua metode yang disebutkan diatas hampir sama, tetapi ada sedikit perbedaan. CPM berusaha untuk mengoptimumkan biaya proyek total (total project cost) bila jangka waktu proyek diperpendek (dengan memperpendek salah satu atau beberapa kegiatan proyek itu). Jadi CPM mengusahakan opitimalisasi biaya total (overhead dan activity cost) untuk jangka waktu penyelesaian yang bisa dicapai.

Analisa network bisa digunakan untuk merencanakan suatu proyek antara lain:

1. Pembangunan rumah, jalan atau jembatan

2. Kegiatan Penelitian.

Teknik Optimasi 
3. Perbaikan, pembongkaran dan pemasangan mesin pabrik.

4. kegiatan-kegiatan advertensi

5. Pembuatan kapal, kapal terbang.

6. Kegiatan-kegiatan penataran dan sebagainya.

PERT didefinisikan sebagai suatu metode untuk menjadwal dan menganggarkan sumber-sumber daya untuk menyelesaikan pada jadwal yang sudah ditentukan

Dua konsep penggunaan PERT :

1. Events (kejadian) : suatu keadaan tertentu yang terjadi pada suatu saat tertentu

2. Aktivitas : suatu pekerjaan yang diperlukan untuk menyelesaikan kejadian tertentu

Contoh jaringan yang sederhana disajikan dengan PERT :

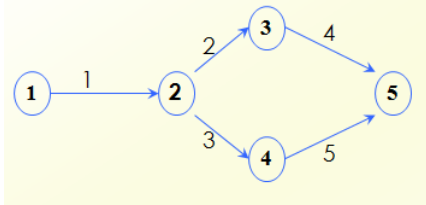

\begin{tabular}{|c|c|}
\hline Event & Aktivitas \\
\hline 1 & $1-2$ \\
\hline 2 & $2-3$ \\
\hline 3 & $2-4$ \\
\hline 4 & $3-5$ \\
\hline 5 & $4-5$ \\
\hline
\end{tabular}

Contoh : Pekerjaan membangun rumah 


\begin{tabular}{c|c|c|c|}
\hline \multicolumn{3}{|c|}{} \\
\hline Aktivitas & Keterangan & $\begin{array}{c}\text { Kegiatan yang } \\
\text { mendahului }\end{array}$ & $\begin{array}{c}\text { Jangka waktu } \\
\text { mengerjakan }\end{array}$ \\
\hline $1-2$ & Membuat pontasi & - & 2 minggu \\
\hline $1-3$ & Membuat atap & - & 4 minggu \\
\hline $2-3$ & Membuat tembok & $1-2$ & 3 minggu \\
\hline $2-4$ & Meratakantanah & $1-2$ & 5 minggu \\
\hline $3-4$ & Finishing & $1-3,2-3$ & 5 minggu \\
\hline
\end{tabular}

Hal yang perlu diperhatikan:

- Sebelum semua kegiatan dimulai, semua kegiatan yang mendahuluinya harus selesai dikerjakan

- Anak panah menunjukkan urutan, panjang dan arahnya tidak menunjukkan letak pekerjaan

- tidak ada nomor pekerjaan yang sama

- 2 buah pekerjaan hanya bisa dihubungkan dengan satu kegiatan

- pada initial event tidak ada pekerjaan yang mendahului Jalur: rangkaian kegiatan yang menghubungkan secara "kontinyu" permulaan proyek sampai dengan akhir proyek

Jalur kritis : jalur yang jml jangka waktu penyelesaian kegiatan-kegiatannya terbesar

Contoh :

Teknik Optimasi 


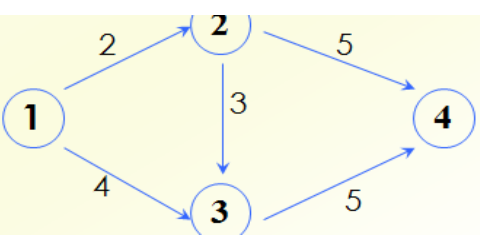

\section{B. Metode Algoritma}

ANALISA NETWORK METODE ALGORITMA

\begin{tabular}{|c|l|c|c|}
\hline Kegiatan & \multicolumn{1}{|c|}{$\begin{array}{c}\text { Keteramgan } \\
\text { Kegiatanyang } \\
\text { maendahului }\end{array}$} & $\begin{array}{c}\text { Walfitu } \\
\text { (mingeu) }\end{array}$ \\
\hline a & Merencanakan & - & 10 \\
\hline b & Memesanmesin & a & 2 \\
\hline c & Menvesuaikanmesin & b & 8 \\
\hline d & Pesanmaterialrangka & a & 4 \\
\hline e & Membuat rangka & d & 3 \\
\hline f & Fisinishing rangka & b,e & 1 \\
\hline g & Pasangmesinpada rangka danstel & c,f & 5 \\
\hline
\end{tabular}

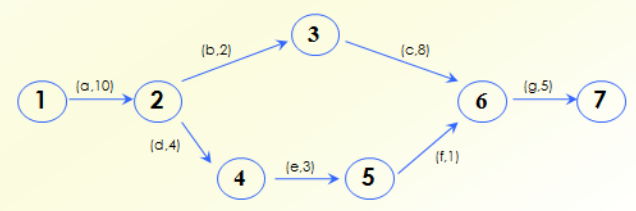

ALGORITMA LS DAN LF

Teknik Optimasi 

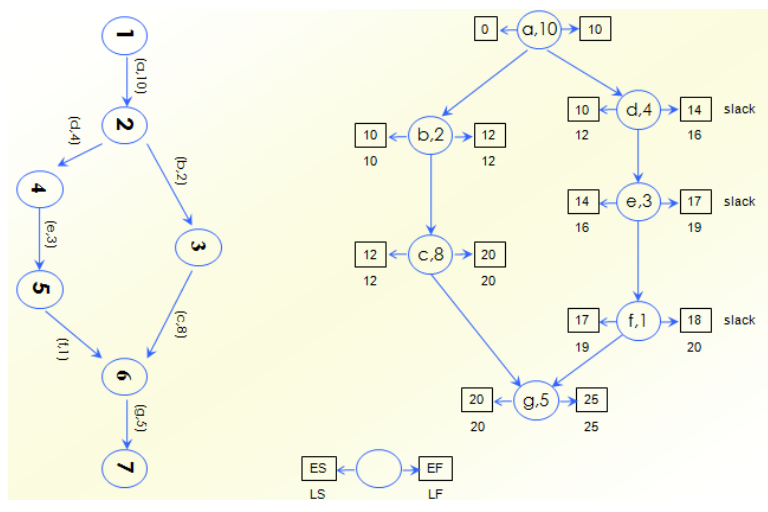

\section{Metode Matriks}

Dalam metode ini akan disusun kegiatan-kegiatan serta waktu yang dibutuhkan ddidalam tabel. Kemudian dari tabel itu dapat kita cari EF dan LF nya. Selanjutnya untuk menentukan jalur kritis dilakukan dengan mencari deretan dari events yang mempunyai $E F=L F$.

\section{Jalur kritis jalur terpanjang}

Misal $X_{i j}$ variabel yang menentukan dilalui (dipilih) atau tidaknya aktivitas aij oleh jalur kritis.

Nilai $X_{i j} \quad 1$ : jika aktivitas $a_{i j}$ terpilih sebagai anggota dari jalur kritis

0 : jika aktivitas $\mathrm{a}_{\mathrm{ij}}$ tidak terpilih 
Contoh dari gambar :

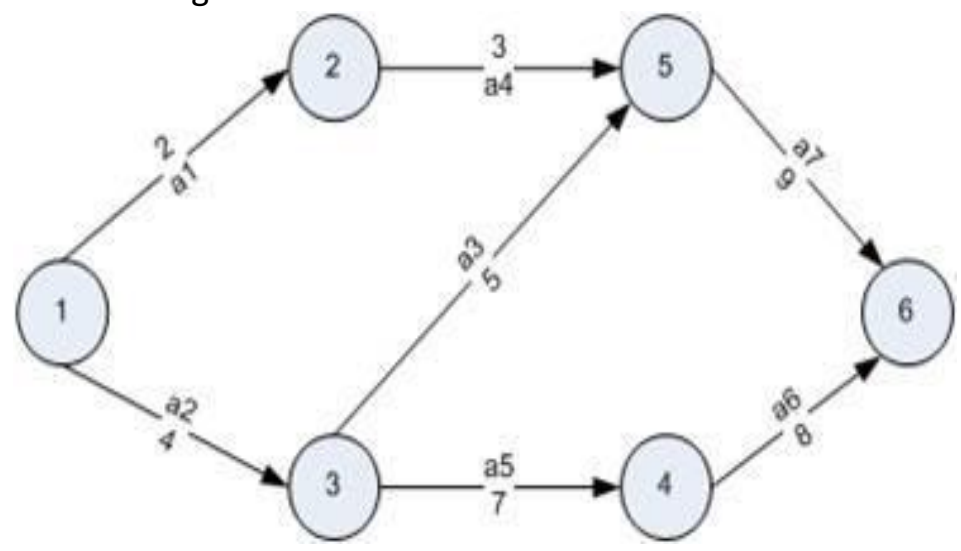

Jalur kritis $=r k\left\{a_{13}, a_{34}, a_{46}\right\}$

Karena $\quad \mathrm{a}_{12} \notin \mathrm{rk} \quad \mathrm{rk}=0$

$$
\mathrm{a}_{13} \in \mathrm{rk} \quad \mathrm{rk}=1
$$

LP :

Tentukan nilai $\mathrm{x}_{12}, \mathrm{x}_{13}, \mathrm{x}_{25}, \mathrm{x}_{34}, \mathrm{x}_{46}, \mathrm{x}_{56}$

Maksimumkan :

$Z=c_{12} x_{12}+c_{13} x_{13}+c_{25} x_{25}+c_{34} x_{34}+c_{46} x_{46}+c_{56} x_{56}$

Teknik Optimasi 
Dengan batasan :

$1=\mathrm{x}_{12}+\mathrm{x}_{13}$ pada titik awal

$\mathrm{X}_{46}+\mathrm{X}_{56}=1$ pada titik akhir

$\mathrm{X}_{13}=\mathrm{X}_{35}+\mathrm{X}_{34}$ dalam rangkaian

$\mathrm{X}_{56}=\mathrm{X}_{25}+\mathrm{X}_{35}$ dalam rangkaian

$\mathrm{x}_{12}, \mathrm{x}_{13}, \mathrm{x}_{25}, \mathrm{x}_{34}, \mathrm{x}_{46}, \mathrm{x}_{56} \in\{0,1\}$

D. Metode Programing

ANALISA NETWORK METODE LINEAR PROGRAMMING

Formulasi

- Maksimumkan $Z=\sum_{(i j) E A} Y_{i j} X_{i j} \longrightarrow$ jalur terpanjang

- Batasan $\longrightarrow$ flow/aliran pekerjaan

1. $\sum_{i B A(1)} X_{i j}=1$

2. $\sum_{i B B(j)} X_{i j}+\sum_{k B A(j)} X_{j k}=0 \quad \mathrm{j}=2,3, \ldots . . \mathrm{n}-1$

3. $\sum_{i B B(n)} X_{i n}=-1$

Fungsi tujuan

Maksimumkan $Z=2 X_{12}+4 X_{13}+3 X_{23}+5 X_{24}+5 X_{34}$

Batasan

$$
\begin{array}{rlr}
X_{12}+X_{13}+X_{23}+X_{24} & = & 1 \\
-X_{12}+X_{34} & = & 0 \\
+X_{13}+X_{23}+X_{24}+X_{34} & = & -1 \\
X_{12}, 4 X_{13}, 3 X_{23}, 5 X_{24}, 5 X_{34} \geq 0 &
\end{array}
$$

\section{E. Memperpendek Waktu Selesainya Proyek}

Teknik Optimasi 


\begin{tabular}{|c|c|c|}
\hline Aktivitas & $\begin{array}{r}\text { Aktivitas } \\
\text { Pendahulu }\end{array}$ & $\begin{array}{c}\text { Waktu } \\
\text { Pelaksanaan } \\
\text { (Minggu) }\end{array}$ \\
\hline A & - & 2 \\
\hline B & - & 4 \\
\hline C & A, B & 5 \\
\hline D & B & 8 \\
\hline E & B & 12 \\
\hline F & C, D & 6 \\
\hline G & E, F & 8 \\
\hline H & F & 7 \\
\hline
\end{tabular}

Teknik Optimasi 
Pembahasan:

network

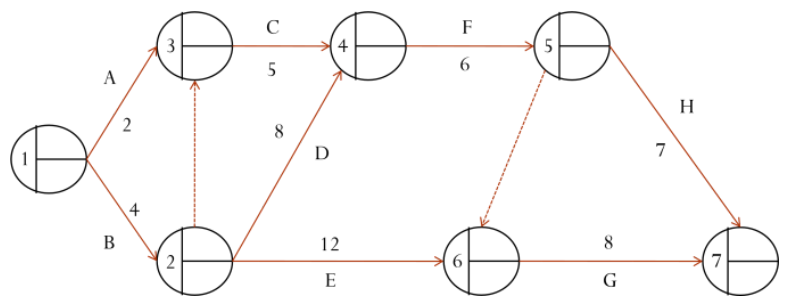

Menghitung ESi

- $\mathrm{ES} 1=0$

- $\mathrm{ES} 2=\max \left\{\mathrm{ES} 1+\mathrm{t}_{12}\right\}=0+4=4$

- $\mathrm{ES} 3=\max \left\{\begin{array}{l}E S 1+t_{13}=0+2=2 \\ E S 2+t_{23}=4+0=4\end{array}\right\}=4$

- $\mathrm{ES} 4=\max \left\{\begin{array}{c}E S 3+t_{34}=4+5=9 \\ E S 2+t_{24}=4+8=12\end{array}\right\}=12$

- $\mathrm{ES} 5=\max \left\{\mathrm{ES} 4+\mathrm{t}_{45}\right\}=12+6=18$

- $\mathrm{ES} 6=\max \left\{\begin{array}{l}E S 5+t_{56}=18+0=18 \\ E S 2+t_{26}=4+12=16\end{array}\right\}=18$

- $\mathrm{ES} 7=\max \left\{\begin{array}{l}E S 5+t_{57}=18+7=25 \\ E S 6+t_{26}=18+8=26\end{array}\right\}=26$ 
Menghitung LSi

- $\operatorname{LS} 7=26$

- $\mathrm{LS} 6=\min \left\{\mathrm{LS} 7-\mathrm{t}_{67}\right\}=26-8=18$

- $\operatorname{LS} 5=\min \left\{\begin{array}{c}L S 7-t_{57}=26-7=19 \\ L S 6-t_{56}=18-0=18\end{array}\right\}=18$

- $\mathrm{LS} 4=\min \left\{\mathrm{LS} 5-\mathrm{t}_{45}\right\}=18-6=12$

- $\operatorname{LS} 3=\min \left\{\mathrm{LS} 4-\mathrm{t}_{34}\right\}=12-5=7$

- $\operatorname{LS} 2=\min \left\{\begin{array}{c}L S 4-t_{24}=12-8=4 \\ L S 6-t_{26}=18-12=6 \\ L S 3-t 23=7-0=7\end{array}\right\}=4$

- $\mathrm{LS} 1=\min \left\{\begin{array}{l}L S 2-t_{12}=4-4=0 \\ L S 3-t_{13}=7-2=5\end{array}\right\}=0$

Menghitung Nilai kritis:

1. Kegiatan $\mathrm{A}$
a. $\mathrm{ES} 1=\mathrm{LS} 1 \quad 0=0$
b. $\mathrm{ES} 3=\mathrm{LS} 3 \quad 4 \neq 7$
C. $\mathrm{ES} 1+\mathrm{t}_{13}=\mathrm{ES} 3 \quad 0+2=4 \quad 2 \neq 4$

2. Kegiatan $\mathbf{B}$
a. $\mathrm{ES} 1=\mathrm{LS} 1 \quad 0=0$
b. $E S 2=L S 2 \quad 4=4$
C. $\mathrm{ES} 1+\mathrm{t}_{12}=\mathrm{ES} 2 \quad 0+4=4 \quad 4=4$

3. Kegiatan D

a. $\quad \mathrm{ES} 2=\mathrm{LS} 2 \quad 4=4$ 

b. $\mathrm{ES} 4=\mathrm{LS} 4 \quad 12=12$
c. $\mathrm{ES} 2+\mathrm{t}_{24}=\mathrm{ES} 4 \quad 4+8=12 \quad 12=12$

4. Kegiatan $\mathrm{E}$
a. $\mathrm{ES2}=\mathrm{LS} 2 \quad 4=4$
b. $\mathrm{ES} 6=\mathrm{LS} 6 \quad 18=18$
c. $\mathrm{ES} 2+\mathrm{t}_{26}=\mathrm{ES} 6 \quad 4+12=18 \quad 16 \neq 18$

5. Kegiatan $\mathrm{F}$
a. $\mathrm{ES} 4=\mathrm{LS} 4 \quad 12=12$
b. $\mathrm{ES} 5=\mathrm{LS} 5 \quad 18=18$
C. $\mathrm{ES} 4+\mathrm{t}_{45}=\mathrm{ES} 5 \quad 12+6=18 \quad 18=18$

6. Kegiatan $\mathrm{H}$
a. $\mathrm{ES} 5=\mathrm{LS} 5 \quad 18=18$
b. $\mathrm{ES7}=\mathrm{LS7} \quad 26=26$
C. $\mathrm{ES} 5+\mathrm{t}_{57}=\mathrm{ES} 7 \quad 18+7=26 \quad 25 \neq 26$

7. Kegiatan $\mathrm{G}$
a. $\mathrm{ES6}=\mathrm{LS} 6 \quad 18=18$
b. $\mathrm{ES7}=\mathrm{LS7} \quad 26=26$
c. $\mathrm{ES} 6+\mathrm{t}_{67}=\mathrm{ES7} \quad 18+8=26 \quad 26=26$

Kegiatan Kritis : B, D, F, Dummy 2, G

Jalur Kritisnya : 1-2-4-5-6-7

Waktu Kritisnya : $4+8+6+0+8=26$

Waktu penyelesaian persoalan diatas minimal 26 minggu 


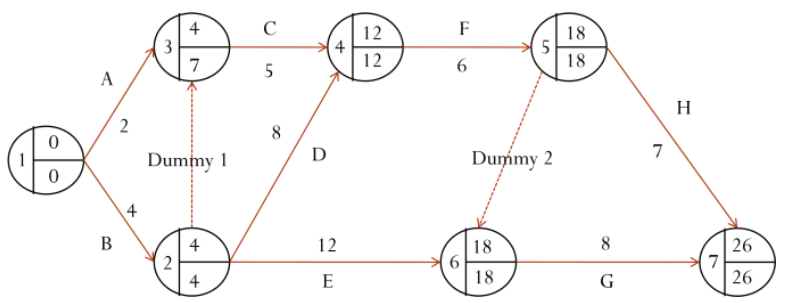

F. Bentuk bentuk lain dari fungsi biaya perpendekan

1. Bentuk fungsi biaya yang convex

2. Bentuk fungsi biaya yang concave

3. Bentuk fungsi biaya yang discontinuous

\section{G. Latihan soal}

1. Diketahui rata-rata kedatangan pelanggan setiap 4 menit (dalam waktu 4 menit ada satu langganan yang datang), rata-rata waktu pelayanan 2,5 menit (untuk melayani seorang pelanggan diperlukan waktu 2,5 menit). Hitunglah:

a) Rata-rata banyaknya para pelanggan dalam sistem

b) Rata-rata banyaknya para pelanggan yang menunggu dalam suatu antrian sebelum menerima layanan

c) Rata-rata waktu seseorang pelanggan menunggu dalam antrian

Rata-rata waktu seseorang pelanggan yang menunggu sebelum menerima layanan

Teknik Optimasi 


\section{A. Pendahuluan}

Antrian adalah suatu kejadian dalam kehidupan sehari-hari. Berikut ini contoh beberapa situasi dimana antrian itu sangat penting.

Contoh Gardu Tol Pengendara motor harus membayar biaya masuk untuk melewati sebuah jembatan. Apakah gardu tol cukup? Bagaimana kita harus mengatur rambu lalu lintas agar waktu tunggu dapat diterima?

Contoh sistem produksi sebuah mesin menghasilkan jenis produk yang berbeda. Berapa waktu pasti dari suatu pesanan? Apa yang mengurangi waktu pasti jika kita memiliki sebuah mesin ekstra? Haruskah kita membuat prioritas dari pesanan?

Antrian itu timbul disebabkan oleh kebutuhan akan sebuah layanan melebihi kemampuan (kapasitas) pelayanan atau fasilitas layanan, sehingga pengguna fasilitas yang tiba tidak bisa segera mendapat layanan disebabkan kesibukan layanan. Pada banyak hal, tambahan fasilitas pelayanan dapat diberikan untuk 
mengurangi antrian atau untuk mencegah timbulnya antrian. Akan tetapi biaya karena memberikan pelayanan tambahan, akan menimbulkan pengurangan keuntungan sampai dibawah tingkat yang dapat diterima. Sebaliknya, sering timbulnya antrian yang panjang akan mengakibatkan hilangnya pelanggan / nasabah.

\section{B. Konsep konsep dasar teori antrian}

Antrian yang sangat panjang dan terlalu lama untuk memperoleh giliran pelayanan sangatlah menjengkelkan. Rata-rata lamanya waktu menunggu (waiting time) sangat tergantung kepada rata-rata tingkat kecepatan pelayanan (rate of services). Teori tentang antrian diketemukan dan dikembangkan oleh A. K. Erlang, seorang insinyur dari Denmark yang bekerja pada perusahaan telepon di Kopenhagen pada tahun 1910. Erlang melakukan sebuah eksperimen tentang fluktuasi dan permintaan atas fasilitas telepon yang berhubungan dengan automatic dialing equipment yaitu sebuah peralatan untuk penyambungan telepon secara otomatis.

Menurut Siagian (1987), antrian ialah suatu garis tunggu dari nasabah (satuan) yang memerlukan layanan dari satu atau lebih pelayan (fasilitas layanan). Pada umumnya sistem antrian dapat diklasifikasikan menjadi sistem yang berbeda-beda dimana 
teori antrian dan simulasi sering diterapkan secara luas. Klasifikasi menurut Hillier dan Lieberman adalah sebagai berikut:

1. Sistem pelayanan komersial

2. Sistem pelayanan bisnis - industry

3. Sistem pelayanan transportasi

4. Sistem pelayanan sosial

\section{Sistem dan struktur antrian}

Ada tiga komponen dalam sistem antrian yaitu :

1. Populasi dan cara kedatangan. pelanggan datang ke dalam sistem

2. Sistem pelayanan.

3. Kondisi pelanggan saat keluar sistem.

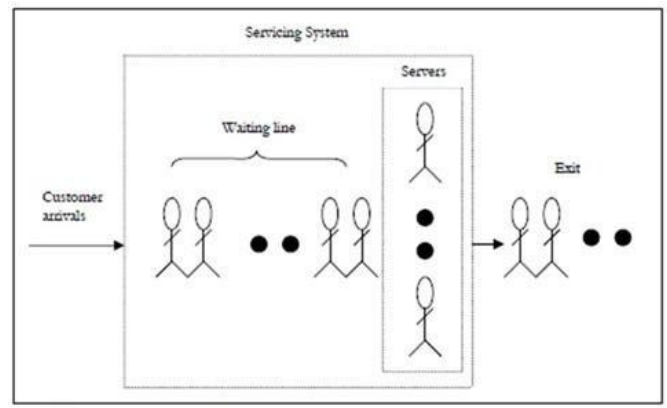

Sowre: Richard Coase a. al, 1998

Populasi dan Cara Kedatangan Pelanggan.

a) Populasi.

Populasi yang akan dilayani (calling population). Setiap masalah antrian yang melibatkan timbul adanya 
kedatangan, misalnya orang, mobil, panggilan telepon untuk dilayani, dan lain-lain. Unsur ini sering dinamakan proses input. Proses input meliputi sumber kedatangan atau biasa dinamakan calling population, cara terjadinya kedatangan yang umumnya merupakan sebua variabel acak.

Karakteristik dari suatu populasi yang akan dilayani (calling population) dapat dilihat menurut ukurannya, pola kedatangan, serta perilaku dari populasi yang akan dilayani. Menurut ukurannya, populasi yang akan dilayani bisa terbatas (finite) bisa juga tidak terbatas (infinite). Sebagai contoh jumlah mahasiswa yang antri untuk registrasi di sebuah pegunungan tinggi sudah diketahui jumlahnya (finite), sedangkan jumlah nasabah bank yang antri untuk setor dan, menarik tabungan, maupun membuka rekening baru, bisa tak terbatas (infinite).

b) Distribusi Kedatangan.

Secara umum, formula garis tunggu antara antraian memerlukan sebua informasi tingkat kedatangan unit per periode waktu (arrival rate). Distribusi kedatangan bisa teratur - tetap dalam satu periode. Artinya kedatangan unit / pelanggan dalam antrian dengan unit / 
pelanggan dan berikutnya memiliki periode waktu yang sama. Kedatangan yang seperti ini biasanya hanya ada di sistem produksi dimana antrian dikendalikan oleh mesin. Kedatangan yang teratur sering dijumpai pada suatu proses pembuatan / pengemasan produk yang sudah distandardisasi. Pada proses semacam ini, kedatangan produk untuk diproses pada bagian selanjutnya biasanya sudah ditentukan batas waktunya, misalnya setiap 30 detik.

Pada banyak kasus dalam praktek, kedatangan unit / pelanggan dalam antrian dengan unit / pelanggan berikutnya bersifat variabel atau acak. Banyak dijumpai misalnya suatu kedatangan nasabah di bank. Pola kedatangan yang sifatnya acak dapat digambarkan dengan distribusi statistik dan dapat ditentukan dua acara yaitu:

1. Dengan cara menganalisa kedatangan per satuan waktu untuk melihat apakah waktu kedatangan unit / pelanggan dalam antrian mengikuti pola distribusi statistik tertentu. Diasumsikan bahwa waktu kedatangan unit / pelanggan dalam antrian dengan 
unit / pelanggan yang berikutnya berdistribusi eksponensial.

2. Dengan cara menetapkan lama waktu (T) dan mencoba menentukan berapa banyak unit / pelanggan yang datang ke dalam sistem dalam kurun waktu T. Secara spesifik biasanya diasumsikan bahwa jumlah kedatangan per satuan waktu mengikuti pola distribusi Poisson.

Ciri distribusi poisson:

i. Rata-rata jumlah kedatangan dari setiap interval bisa diestimasikan dari data sebelumnya.

ii. Bila interval waktu diperkecil misalnya dari 10 menit menjadi 5 menit, maka pernyataan ini benar.

Probabilitas $\mathrm{n}$ kedatangan dalam waktu $\mathrm{T}$ ditentukan dengan rumus:

$$
\mathrm{P}(\mathrm{n}, \mathrm{T})=\frac{e^{-\lambda \mathrm{T}}(\lambda \mathrm{T})^{\mathrm{n}}}{\mathrm{n} !} \mathrm{n}=0,1,2, \ldots
$$

Dimana:

$$
\begin{array}{ll}
\lambda & =\text { rata-rata kedatangan per satuan waktu } \\
\mathrm{T} & =\text { periode waktu } \\
\mathrm{n} & =\text { jumlah kedatangan dalam waktu } \mathrm{T} \\
\mathrm{P}(\mathrm{n}, \mathrm{T}) & =\text { probabilitas } \mathrm{n} \text { kedatangan dalam waktu } \mathrm{T}
\end{array}
$$

Teknik Optimasi 
Jika kedatangan mengikuti Distribusi Poisson dapat ditunjukkan secara matematika bahwa waktu antar kedatangan akan terdistribusi sesuai dengan distribusi eksponensial.

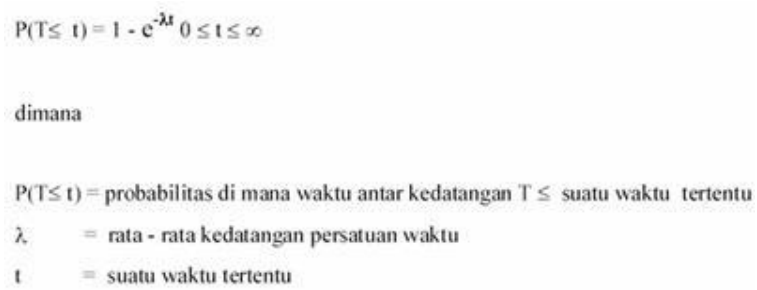

Suatu faktor yang mempengaruhi penilaian distribusi kedatangan adalah ukuran populasi panggilan. Contoh: jika seorang tukan reparasi sedang memperbaiki enam buah mesin, populasi panggilan dibatasi sampai dengan enam buah mesin. Dalam hal ini tidak mungkin bahwa kedatangan mengikuti Distribusi Poisson sebab tingkat kecepatan kerusakan tidak konstan. Jika lima buah mesin telah rusak, tingkat kedatangan lebihi rendah daripada bila seluruh mesin dalam keadaan operasi.

Populasi yang akan dilayani mempunyai perilaku yang berbeda-beda dalam membentuk antrian. Ada tiga jenis perilaku: reneging, balking, dan jockeying. Reneging menggambarkan situasi dimana seseorang masuk dalam 
antria, namun belum juga memperoleh pelayanan, kemudian meninggalkan sebuah antrian tersebut. Balking menggambarkan orang yang tidak masuk dalam antrian dan langsung meninggalkan tempat antrian. Jockeying menggambarkan orang yang pindah-pindah antrian.

\section{Struktur Antrian}

Proses antrian itu pada umumnya dikelompokkan ke dalam empat struktur menurut sifat-sifat fasilitas pelayanan, yaitu:

1. Satu saluran satu tahap

2. Banyak saluran satu tahap

3. Satu saluran banyak tahap

4. Banyak saluran banyak tahap

Keempat kelompok ini ditunjukkan pada gambar berikut:

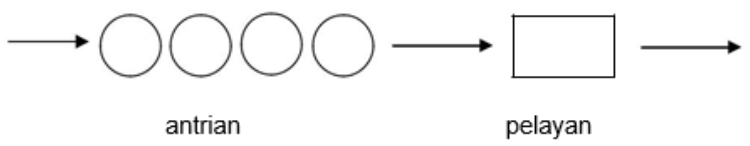



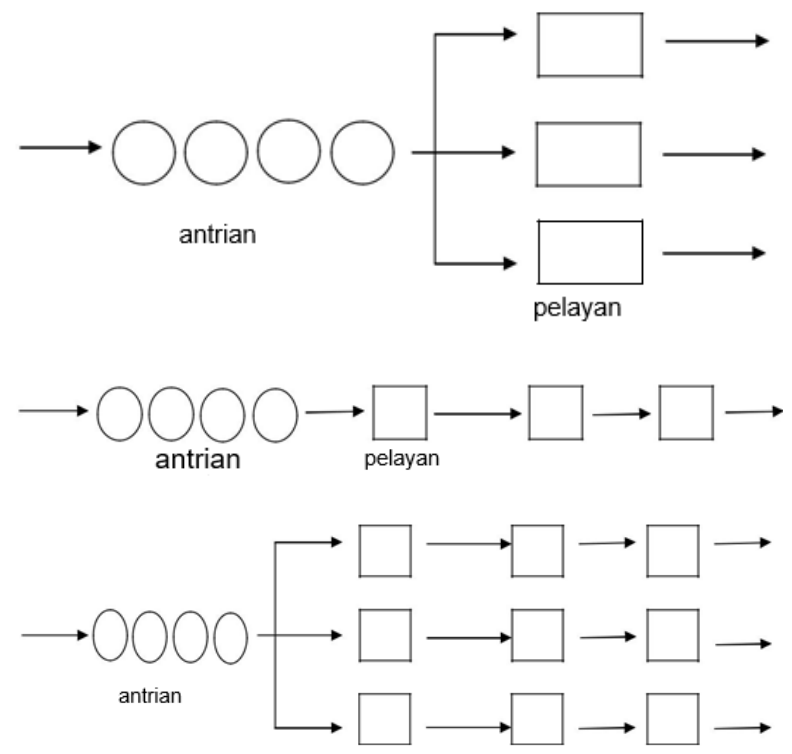

Gambar 2. Struktur Dasar Proses Antrian

Banyaknya saluran dalam proses antrian adalah jumlah pelayanan pararel yang tersedia. Banyaknya tahap menunjukkan jumlah pelayanan berurutan yang harus dilalui oleh setiap kedatangan. Gambar diatas dapat menunjukkan struktur antrian dengan tiga saluran satu tahap. Empat kategori yang disajikan di atas merupakan kategori dasar. Masih banyak variasi struktur antrian yang lain.

\section{Model-model antrian}

Teknik Optimasi 
Empat model yang paling sering digunakan memiliki tiga karakteristik umum dengan menggunakan asumsi yaitu:

1. Kedatangan berdistribusi Poisson

2. Penggunaan aturan FIFO

3. Pelayanan satu tahap

a. Model A: Model Antrian Jalur Tunggal Dengan Kedatangan Berdistribusi Poisson Dan Waktu Pelayanan Eksponensial.

Permasalahan antrian yang paling umum mencakup jalur antrian jalur tunggal atau satu stasiun pelayanan. Dalam situasi ini, kedatangan membentuk satu jalur tunggal untuk dilayani oleh stasiun tunggal. Diasumsikan sistem berada dalam kondisi berikut:

1. Kedatangan dilayani atas dasar first-in,first-out (FIFO) dan setiap kedatangan menunggu untuk dilayani, terlepas dari panjang antrian.

2. Kedatangan tidak bisa terikat pada kedatangan yang sebelumnya, hanya saja jumlah kedatangan rata-rata tidak berubah menurut waktu.

3. Kedatangan dapat digambarkan dengan distribusi probabilitas Poisson dan datang dari sebuah populasi yang tidak terbatas (atau sangat besar).

Teknik Optimasi 
4. Waktu pelayanan bervariasi dari satu pelanggan dengan pelanggan yang berikutnya dan tidak terikat satu sama lain, tetapi tingkat rata-rata waktu pelayanan diketahui.

5. Waktu pelayanan sesuai dengan distribusi probabilitas eksponensial negative.

6. Tingkat pelayanan lebih cepat daripada tingkat kedatangan.

\section{b. Model B: Antrian jalur berganda}

Sistem antrian jalur berganda dimana terdapat dua atau lebih jalur atau stasiun pelayanan yang tersedia untuk menangani pelanggan yang datang. Asumsi bahwa pelanggan menunggu pelayanan membentuk satu jalur dan akan dilayani pada stasiun pelayanan yang tersedia pertama kali pada saat itu. Bentuk antrian jalur berganda, satu tahap masih banyak ditemukan pada sebagian besar bank saat ini. Sebuah jalur umum dibuat, dan pelanggan yang berada di barisan terdepan yang pertama kali dilayani oleh kasir. Sistem suatu jalur berganda yang ditunjukkan dalam Contoh D3 yang mengasumsikan bahwa ada pola kedatangan yang mengikuti distribusi Poisson dan waktu pelayanan yang mengikuti distribusi 
eksponensial negatif. Pelayanan dilakukan secara first-come, first-served, dan semua stasiun pelayanan diasumsikan memiliki tingkat pelayanan yang sama. Asumsi lain yang terdapat dalam model jalur tunggal juga berlaku.

\section{c. Model C: Model Waktu Pelayanan Konstan}

Beberapa sistem pelayanan memiliki waktu pelayanan yang tetap, dan bukan berdistribusi eksponensial seperti biasanya. Di saat pelanggan diproses menurut sebuah siklus tertentu seperti pada kasus dari pencurian mobil otomatis atau wahana di taman hiburan, waktu pelayanan yang terjadi pada umumnya konstan. Oleh karena itu tingkat waktu yang konstan ini tetap, maka nilai-nilai $L_{q}, W_{q}, L_{s}$, dan $W_{s}$, selalu lebih kecil dari pada nilai-nilai tersebut dalam Model $A$, yang memiliki tingkat pelayanan bervariasi. Sesungguhnya, baik rata-rata panjang antrian dan rata-rata waktu menunggu dalam antrian separuh dari nilai tersebut dalam Model C.

\section{d. Model D: Model Populasi yang Terbatas}

Ketika terdapat sebuah populasi pelanggan potensial yang terbatas bagi sebuah fasilitas pelayanan, maka model antrian berbeda harus dipertimbangkan. Sebagai contoh model ini akan digunakan, untuk pekerjaan 
perbaikan peralatan dalam sebuah pabrik yang memiliki 5 mesin, untuk memelihara sebuah armada yang terdiri dari 10 buah pesawat terbang, atau untuk menjalankan sebuah rumah sakit yang memiliki 20 tempat tidur. Model populasi terbatas dan hanya memungkinkan pertimbangan sejumlah berapapun orang yang melakukan reparasi (pelayanan). Model ini berbeda dengan ketiga model antrian sebelumnya, karena saat ini terdapat hubungan saling ketergantungan antara panjang antrian dan tingkat kedatangan. Situasi ekstrim tersebut dapat digambarkan sebagai berikut: sebuah pabrik memiliki 5 mesin dan semuanya rusak dan sedang menunggu untuk diperbaiki, maka tingkat kedatangan mesin atau pelanggan menurun.

\section{E. Model-model dan aplikasinya}

1. Aplikasi Teori sebuah Antrian Model Single - channel Queuing : Poisson distributed Arrival and exponentially distributed service time.

Sebuah perusahaan lokal yang menyewakan furniture mempunyai satu Gudang dengan satu mesin pengangkut yang dioperasikan oleh satu kelompok yang terdiri dari tiga orang para tenaga kerja. Pemimpin perusahaan 
melihat pada jam-jam tertentu terjadi antrian truk tetapi di saat yang lain, petugas itu yang mengoperasikan mesin menganggur. Dari data yang telah lalu, diketahui rata-rata kedatangan 4 truk per jam, dan rata-rata pelayanan 6 truk per jam. Untuk mengatasi masalah tersebut, pimpinan perusahaan merencanakan untuk menambah kelompok tenaga kerja untuk mengoperasikan mesin. Bagaimana dampak penambahan kelompok tenaga kerja terhadap biaya total yang dikeluarkan perusahaan jika biaya sewa truk \$20 per jam, sedang upah tenaga kerja untuk mengoperasikan mesin $\$ 60$ per orang pre jam. Diasumsikan jika perusahaan menggunakan dua kelompok tenaga kerja maka rata-rata pelayanan menjadi 12 truk per jam dan jika perusahaan menggunakan tiga kelompok tenaga kerja maka rata-rata pelayanan menjadi 18 truk per jam. 1 hari 8 jam kerja.

Pembahasan:

Perkiraan prestasi dari sistem antrian dapat digambarkan misalnya, rata-rata jumlah kedatangan dalam antrian, rata-rata waktu tunggu dari suatu kedatangan dan persentase waktu luang dari pelayanan. Ukuran prestasi ini dapat digunakan untuk memutuskan jumlah pelayanan yang harus diberikan, perubahan yang harus 
dilakukan dalam kecepatan pelayanan atau perubahan lain dalam sistem antrian. Dengan sasaran pelayanan, jumlah pelayan dapat ditentukan tanpa berpatokan pada biaya waktu tunggu. Ukuran prestasi dan parameter model antrian ditentukan dengan notasi sebagai berikut: $\lambda=$ rata-rata kecepatan kedatangan (jumlah kedatangan persatuan waktu) $1 / \lambda=$ rata-rata waktu antar kedatangan $\mu=$ rata-rata kecepatan pelayanan (jumlah satuan yang dilayani persatuan waktu bila pelayan sibuk)

$1 / \mu=$ rata-rata waktu yang dibutuhkan pelayan

$\rho=$ faktor penggunaan pelayanan (proporsi waktu pelayan ketika sedang sibuk)

$\mathrm{Pn}=$ probabilitas bahwa $\mathrm{n}$ satuan (kedatangan) dalam sistem

$\mathrm{L}_{\mathrm{q}}=$ rata-rata jumlah satuan dalam antrian (rata-rata panjang antrian)

$\mathrm{L}_{\mathrm{s}}=$ rata-rata jumlah satuan dalam sistem $\mathrm{W}_{\mathrm{q}}=$ rata-rata waktu tunggu dalam antrian $\mathrm{W}_{\mathrm{s}}=$ rata-rata waktu tunggu dalam sistem

Dalam kasus ini antrian yang didasarkan pada asumsi berikut:

1. Satu pelayanan dan satu tahap

Teknik Optimasi 
2. Jumlah kedatangan per unit waktu digambarkan oleh Dlstribusi Poisson dengan $\lambda=$ rata-rata kecepatan kedatangan

3. Waktu pelayanan eksponensial dengan $\mu=$ rata-rata kecepatan pelayanan

4. Disiplin antrian adalah first come first served seluruh kedatangan dalam barisan hingga dilayani

5. Dimungkinkan panjang barisan yang tak terhingga

6. Populasi yang dilayani tidak terbatas

7. Rata-rata kedatangan lebih kecil dari rata-rata waktu pelayanan

Dari asumsi tersebut dapat diperoleh secara statistic sebagai berikut:

$\mathrm{P}_{\mathrm{w}}=$ probabilitas fasilitas layanan sibuk atau factor utilisasi fasilitas $=\lambda / \mu$

$\mathrm{L}_{\mathrm{q}}=$ jumlah rata-rata dalam antrian

$$
L q=\frac{\lambda^{2}}{\mu(\mu-\lambda)}
$$

$\mathrm{L}_{\mathrm{s}}=$ jumlah rata-rata di dalam sistem (yang antri dan yang sedang dilayani)

$$
L s=\frac{\lambda}{\mu-\lambda}
$$

$\mathrm{W}_{\mathrm{q}}=$ waktu rata-rata di dalam antrian

Teknik Optimasi 


$$
W q=\frac{\lambda}{\mu(\mu-\lambda)}
$$

$\mathrm{W}_{\mathrm{s}}=$ waktu rata-rata di dalam sistem

$$
W s=\frac{1}{\mu-\lambda}
$$

Jumlah rata-rata dalam antrian

1 kelompok kerja

$$
L q=\frac{\lambda^{2}}{\mu(\mu-\lambda)}=\frac{4^{2}}{6(6-4)}=1,332
$$

2 kelompok kerja

$$
L q=\frac{\lambda^{2}}{\mu(\mu-\lambda)}=\frac{4^{2}}{12(12-4)}=0,167
$$

3 kelompok kerja

$$
L q=\frac{\lambda^{2}}{\mu(\mu-\lambda)}=\frac{4^{2}}{18(18-4)}=0,063
$$

Jumlah rata-rata di dalam sistem (yang antri dan yang sedang dilayani)

1 kelompok kerja

$$
L s=\frac{4}{6-4}=2
$$

2 kelompok kerja 


$$
L s=\frac{4}{12-4}=0,5
$$

3 kelompok kerja

$$
L s=\frac{4}{18-4}=0,286
$$

Waktu rata-rata di dalam antrian

1 kelompok

$$
W q=\frac{4}{6(6-4)}=0,333
$$

2 kelompok

$$
W q=\frac{4}{12(12-4)}=0,0422
$$

3 kelompok

$$
W q=\frac{4}{18(18-4)}=0,016
$$

Waktu rata-rata di dalam sistem

1 kelompok

$$
W s=\frac{1}{6-4}=0,5
$$

2 kelompok

$$
W s=\frac{1}{12-4}=0,125
$$

3 kelompok

Teknik Optimasi 


$$
W s=\frac{1}{18-4}=0,071
$$

Probabilitas fasilitas layanan sibuk atau factor utilisasi fasilitas

1 kelompok

$$
P w=\frac{4}{6}=0,667
$$

2 kelompok

$$
P w=\frac{4}{12}=0,333
$$

3 kelompok

$$
P w=\frac{4}{18}=0,222
$$

Perbandingan penggunaan 1, 2, dan 3 kelompok

\begin{tabular}{lrrrr} 
& & 2 & \multicolumn{2}{l}{3} \\
& I kelompok & kelompok & kelompok \\
\hline Rata-rata jumlah truk dalam antrian (Lq) & 1.333 & 0.167 & 0.063 \\
Rata-rata jumlah truk dalam sistem (Ls) & 2.000 & 0.500 & 0.286 \\
Rata-rata waktu truk dalam antrian (Wq) & 0.333 & 0.042 & 0.016 \\
Rata-rata waktu truk dalam sistem (Ws) & 0.500 & 0.125 & 0.071 \\
Probabilitas fasilitas jasa sibuk (Pw) & 0.667 & 0.333 & 0.222
\end{tabular}

Perbandingan Biaya Total Penggunaan 1, 2, dan 3 kelompok 


\begin{tabular}{|c|c|c|c|}
\hline & Biasa Truk per hari & Biaya tenag keria per hari & \begin{tabular}{|l|l|} 
Biaza lotal \\
\end{tabular} \\
\hline Thelompok & $2 \times 8 j \operatorname{am} \times \$ 20 \quad 5320$ & $3 \times \$ 6 \times 8 j \mathrm{jm}-51 \mathrm{HH}$ & Stat \\
\hline 2 kelompok & $0,5 \times 8$ jam $\times \$ 20=\$ 80$ & $6 \times \$ 6 \times 8$ jian $=\$ 288$ & $\$ 368$ \\
\hline 3 kelompok & $0,286 \times 8$ jann $\times \$ 2046$ & $9 \times 56 \times 8$ jam $=5432$ & $\$ 478$ \\
\hline
\end{tabular}

Dari perhitungan biaya total terlihat bahwa biaya total yang paling rendah jika perusahaan hanya mempekerjakan dua kelompok tenaga kerja. Dengan demikian disarankan agar perusahaan tersebut menambah satu kelompok tenaga kerja.

\section{Aplikasi Teori Antrian Model M/M/1 di Bank CIMB.}

Bank CIMB Jogjakarta melakukan aktivitas pelayanan kepada nasabah yang akan menyimpan uang dan mengambil uangnya di bank tersebut. Rata-rata kedatangan pelanggan di bank tersebut mengikuti distribusi poisson yaitu 20 pelanggan per jam. Bank CIMB Jogjakarta dapat melayani rata-rata 25 pelanggan per jam, dengan waktu pelayanan setiap pelanggan yang mengikuti distribusi probabilitas eksponensial. Hitunglah soal-soal berikut:

1. Tingkatan intensitas fasilitas pelayanan $(p)$

2. Jumlah rata-rata pelanggan yang diharapkan dalam sistem

3. Jumlah pelanggan yang diharapkan menunggu dalam antrian 
4. Waktu yang diharapkan oleh setiap pelanggan selama dalam sistem (menunggu dalam pelayanan)

5. Waktu yang diharapkan oleh setiap pelanggan untuk menunggu dalam antrian.

Pembahasan:

1. Dari kasus diatas memiliki rata-rata kedatangan $=20$ atau rata-rata waktu pelayanan $=25$, oleh karena itu dengan bantuan software POM for windows maka data tersebut dapat diolah dengan prosedur sebagai berikut:

- Klik - Module - Waiting Lines - M/M/1 (exponential service time) - Title: CIMB - Cost

- Analysis: No Cost-OK

- Kemudian data rata-rata kedatangan = 20 atau rata-rata waktu pelayanan $=25$, masukkan seperti berikut ini:

- Masukkan data antrian di Bank CIMB

\begin{tabular}{|l|r|}
\hline Parameter & Value \\
\hline M/M/1 [exponential & \\
\hline Arrival rate(lambda) & 20 \\
\hline Service rate(mu) & 25 \\
\hline Number of servers & 1 \\
\hline
\end{tabular}

- Kemudian dari data tersebut diolah (klik solve) sehingga diperoleh keluaran seperti berikut: 


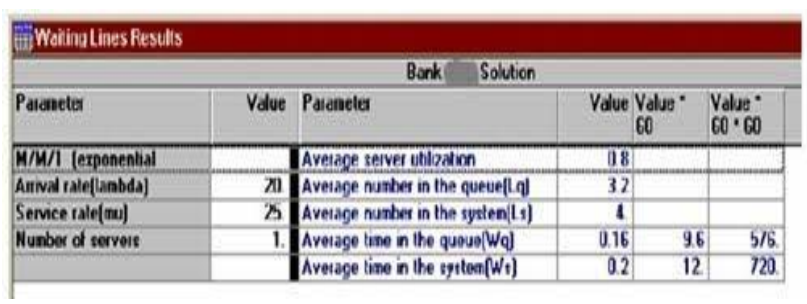

Keterangan:

1. Tingkat intensitas / rata-rata pelayanan atau $\mathrm{p}$ (Average server utilization) $=0,8$. Angka tersebut menunjukkan bahwa pelayanan (kasir) akan sibuk melayani nasabah selama $80 \%$ dari waktunya. Sedangkan $20 \%$ dari waktunya atau (1-p) atau $(1-0,80)$ yang sering disebut idle time akan digunakan pelayan (kasir) untuk istirahat, membereskan berkas dan lain-lain.

2. Jumlah rata-rata pelanggan yang diharapkan dalam sistem atau $L$ (Average number in the system) $=4$. Angka tersebut menunjukkan bahwa pelayan dapat mengharapkan 4 nasabah yang berada dalam sistem.

3. Jumlah pelanggan yang diharapkan menunggu dalam antrian atau Lq (Average number in the Queu) = 3,2. Angka tersebut menunjukkan 
bahwa nasabah yang menunggu untuk dilayani dalam antrian sebanyak 3, 20 nasabah.

4. Waktu yang diharapkan pelanggan selama dalam sistem atau W (Average time in the system) $=0,2$ jam atau 12 menit. Angka tersebut menunjukkan bahwa waktu rata-rata nasabah menunggu dalam sistem selama 12 menit.

5. Waktu yang diharapkan oleh pelanggan selama menunggu dalam antrian atau Wq (Average time in Queu) =0,16 jam atau 9,6 menit. Angka tersebut menunjukkan bahwa rata-rata nasabah menunggu dalam antrian selama 9,6 menit. Untuk menggunakan persamaan probabilitas kepastian jumlah pelanggan yang ada dalam sistem dihitung dengan P0 + P1 + P2 + P4, dimana:

$$
P_{\mathrm{n}}=\mathrm{P}^{\mathrm{n}}(1-\mathrm{P})
$$

Atau

$$
\begin{aligned}
P_{\mathrm{n}} & =(0,80)^{\mathrm{n}}(1-0,80) \\
& =(0,80)^{\mathrm{n}}(0,20)
\end{aligned}
$$


Hasil perhitungan Pn (M/M/1) dapat dilihat pada table probabilitas dan hasil olahan POM for Windows yaitu sebagai berikut:

\begin{tabular}{|c|c|c|c|}
\hline$k$ & Prob (num in sys) $=k$ & Prob (num in sys) $<=k$ & Prob (num in sys) >k \\
\hline q & 0.2 & 0.2 & 0.8 \\
\hline 1 & 0.16 & 0.36 & 0.64 \\
\hline 2 & 0.128 & 0.488 & 0.512 \\
\hline 3 & 0.1024 & 0.5904 & 0.4096 \\
\hline 4 & $8.19 \mathrm{E}-02$ & 0.67232 & 0.32768 \\
\hline 5 & $65.5 \mathrm{E}-02$ & 0.737256 & 0262144 \\
\hline क & $524 \mathrm{E}: 02$ & 0.7902848 & 0.2097152 \\
\hline 7 & 4.19E -02 & 0.8322279 & 0.1677721 \\
\hline 8 & $336 \mathrm{E}-02$ & 0.8557823 & 0.1342177 \\
\hline 9 & 2.68E-02 & 0.8926259 & 0.1073741 \\
\hline 10 & $2.15 \mathrm{E}-02$ & 0.9141007 & $8.596-02$ \\
\hline 11 & $1.72 E-02$ & 0.9312806 & $687 E-0 \mathrm{C}$ \\
\hline 12 & 0.0137439 & 0.9450244 & 5.505 .02 \\
\hline 13 & $1.10 \mathrm{E}-02$ & 0.9560195 & $4.40 E-02$ \\
\hline 14 & $8.80 \mathrm{E}-03$ & 0.9548156 & $3.52 E-02$ \\
\hline 15 & $7,04 \mathrm{E}-03$ & 0.9718525 & $281 \mathrm{E}-0 \mathrm{C}$ \\
\hline 10 & 5.63E:03 & 0.977482 & $2.25 E-02$ \\
\hline 17 & $4.50 \mathrm{E}-03$ & 0.9819856 & $1.80 \in-00$ \\
\hline 18 & $360 \mathrm{E}-03$ & 0.9855884 & $1.44 E-02$ \\
\hline 19 & $2.85 \mathrm{E}-03$ & 0.9884707 & $1.15 E-0 a$ \\
\hline 20 & $2.31 \mathrm{E}-03$ & 0.9907766 & $9.226-03$ \\
\hline 21 & $1.84 \mathrm{E}-03$ & 0.9926213 & $7.38<-03$ \\
\hline 22 & $148 \mathrm{E}-03$ & $0.994097:$ & 5.900 .03 \\
\hline 23 & 1.18E-03 & 0.9952776 & $4.72 E-03$ \\
\hline 24 & $9.44 \mathrm{E}-04$ & 0.9962221 & $378 E-03$ \\
\hline 25 & $756 \mathrm{E}-04$ & 0.9969777 & $302 E-0 s$ \\
\hline 25 & $6.04 E-04$ & 0.9975822 & $2.42 E-03$ \\
\hline 27 & $484 \mathrm{E}-04$ & 0.9980658 & $1.93 E-03$ \\
\hline 29 & $387 \mathrm{E}-04$ & 0.9984526 & $1.55 E-03$ \\
\hline 29 & $3.09 \mathrm{E}-04$ & 0.9987621 & $1.24 E-03$ \\
\hline 30 & $2.48 E-04$ & 0.9956097 & $9.90 E-04$ \\
\hline
\end{tabular}

Jika dilihat pada kolom Prob (num in sys) $=k$, dapat diinterpretasikan, misalnya untuk probabilitas 4 
pelanggan berada dalam sistem pelayanan sebesar 0,082 atau 8,2\%. Dari tabel diatas dapat digambarkan grafik antrian (M/M/1) dari nasabah bank CIMB adalah sebagai berikut:

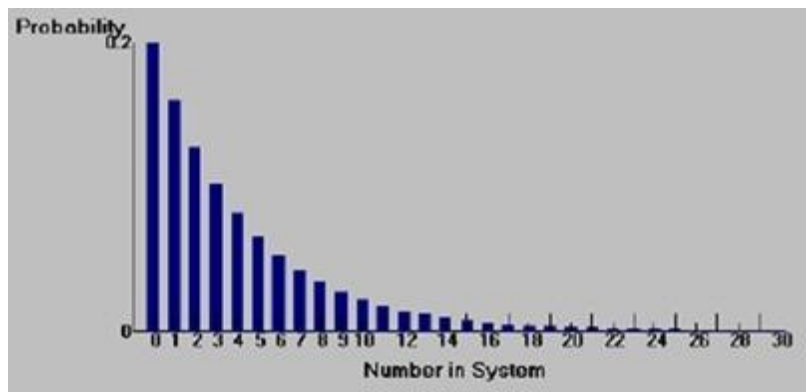

3. Aplikasi Teori Antrian- Model Multiple - Channel.

Dasar yang digunakan dalam multiple-channel model adalah sistem (M/M/s). perbedaannya dengan single - channel model adalah terletak pada jumlah fasilitas pelayanan. Dalam multiple - channel model, fasilitas pelayanan yang dimiliki lebih dari satu. Huruf (s) yang terdapat dalam sistem $(\mathrm{M} / \mathrm{M} / \mathrm{s})$.

Contoh Kasus Multiple - Channel Model (Model M/M/s) dengan jumlah kasir di bank CIMB. Bank CIMB telah mencoba memasang 5 kasir yang diperlukan untuk melayani para nasabah yang ada di ruang lobby, dengan menggunakan sistem $(\mathrm{M} / \mathrm{M} / \mathrm{s})$. Tingkat kedatangan nasabah di bank rata-rata 40 orang per jam. Setiap kasir 
bank rata-rata dapat melayani 10 nasabah per jam. Jika diasumsikan pada model sistem antrian yang digunakan bank adalah (M/M/s), hitunglah soal-soal berikut:

1. Tingkat intensitas fasilitas pelayanan $(p)$

2. Jumlah rata-rata pelanggan yang diharapkan menunggu dalam antrian

3. Jumlah pelanggan yang diharapkan menunggu dalam antrian

4. Waktu yang diharapkan oleh setiap pelanggan selama dalam sistem (menunggu dalam pelayanan)

5. Waktu yang diharapkan oleh setiap pelanggan untuk menunggu dalam antrian.

Pembahasan:

Dari kasus diatas kita memiliki tingkat kedatangan nasabah di bank rata-rata 40 orang per jam. Setiap kasir bank rata-rata dapat melayani 10 nasabah per jam, oleh karena itu petugas dengan menggunakan sebuah bantuan software POM for windows maka data tersebut dapat diolah dengan prosedur sebagai berikut:

- Klik - Module - Waiting Lines - M/M/s - Title: CIMB Cost Analysis: No Cost - OK

- Kemudian data tingkat kedatangan nasabah di bank rata-rata 40 orang per jam dan setiap kasir bank

Teknik Optimasi 
rata-rata dapat melayani 10 nasabah per jam, masukkan seperi berikut:

- Masukkan data Antrian di Bank CIMB

\begin{tabular}{|l|r|}
\hline Parameter & Value \\
\hline M/M/s & \\
\hline Arrival rate[lambda] & $\mathbf{4 0}$ \\
\hline Service rate[mu] & 10 \\
\hline Number of servers & 5 \\
\hline
\end{tabular}

- Kemudian dari data tersebut diolah (klik solve) sehingga diperoleh keluaran seperti berikut:

\begin{tabular}{|c|c|c|c|c|}
\hline \multicolumn{5}{|c|}{ Weinglins foseds } \\
\hline \multicolumn{5}{|c|}{ Marabuh toduin } \\
\hline Panelei & $V d x$ & Peaster & Vate Vidon & $\begin{array}{l}\text { Ydus: } \\
60 \cdot 60\end{array}$ \\
\hline W/Wh & & Averige teive Gitizxn & 08 & \\
\hline Aired iotelantodal & 40. & Avecego nuaber in the evoue(ta) & 22165 & \\
\hline Sermeo iate(ay) & 10. & Averago nunber in the igiter(t) & 6.216 & \\
\hline \multirow[t]{2}{*}{ Hunba d semen } & 5. & Areceese bre in the evar (WVI) & 0,003 & 199406 \\
\hline & & Average tese in the igiten(W/) & Q.1SA 2301 & 5sitex \\
\hline
\end{tabular}

Keterangan:

1. Tingkat intensitas / rata - rata kegunaan dan pelayanan atau p (Average server utilization) 0,8. angkat tersebut menunjukkan bahwa pelayan (kasir) akan sibuk melayani nasabah selam $80 \%$ dari waktunya. Sedangkan $20 \%$ dari waktunya atau (1 -

p) atau $(1-0,80)$ yang sering disebut idle time akan

Teknik Optimasi 
digunakan pelayan (kasir) untuk istirahat, membereskan berkas dan lain-lain.

2. Jumlah rata-rata pelanggan yang diharapkan dalam sistem atau $L$ (Average number in the system) = 6,2. Angka tersebut menunjukkan bahwa pelayan dapat mengharapkan 6,2 nasabah yang berada dalam sistem.

3. Jumlah pelanggan yang diharapkan menunggu dalam antrian atau Lq (Average number in the Queu) = 2,2 nasabah.

4. Waktu yang diharapkan pelanggan selama dalam sistem atau $\mathrm{W}$ (Average time in the system) $=0,15$ jam atau 9 menit. Angka tersebut menunjukkan bahwa waktu rata-rata nasabah menunggu dalam sistem selama 9 menit.

5. Waktu yang diharapkan oleh pelanggan selama menunggu dalam antrian atau $\mathrm{Wq}$ (Average time in Queu) = 0, 055 jam atau 3,3 menit. Angka tersebut menunjukkan bahwa rata-rata nasabah menunggu dalam antrian selam 3,3 menit. Untuk menggunakan suatu persamaan yang probabilitas sebuah kepastian jumlah pelanggan yang ada dalam 
sistem dihitung dengan menjumlahkan $\mathrm{P} 0+\mathrm{P} 1+\mathrm{P} 2$

+ P4, dimana:

$$
P_{n}=P^{n}(1-p)
$$

Atau

$$
\begin{aligned}
P_{\mathrm{n}} & =(0,80)^{\mathrm{n}}(1-0,80) \\
& =(0,80)^{\mathrm{n}}(0,20)
\end{aligned}
$$

Hasil perhitungan $\mathrm{Pn}(\mathrm{M} / \mathrm{M} / \mathrm{s})$ dapat dilihat pada tabel probabilitaas hasil olahan POM for windows yaitu seperti berikut: 


\begin{tabular}{|c|c|c|c|}
\hline$K$ & Prob (num in sys) $=k$ & Prob (num in sys) $<=k$ & Prob (num in sys) $>k$ \\
\hline d & $1,30 \mathrm{E}-02$ & $130 \mathrm{E}-02$ & 0.987013 \\
\hline 1 & 5.19E-02 & $649 \mathrm{E}-02$ & $0.9350<49$ \\
\hline 2 & 0.1038961 & 0.1688312 & 0.8311688 \\
\hline 3 & 0.1385281 & 0.3073599 & 0.6926407 \\
\hline 4 & 0.1385281 & 0.4458874 & 0.5541126 \\
\hline 5 & 0.1108225 & 0.5567099 & 04432901 \\
\hline क & D 088658 & 0.6453679 & 0.3546321 \\
\hline $\overrightarrow{0}$ & $7,09 \mathrm{E} \cdot \mathrm{a2}$ & 0.7162943 & D. 2837057 \\
\hline sf & $5.67 \mathrm{E}-02$ & 0.7730354 & 0.2269645 \\
\hline 9 & 0.0453929 & 0.8184283 & 0.1815717 \\
\hline 10 & 3.63E- 02 & 0.8547426 & 0.1452574 \\
\hline 11 & 2.91E-02 & 0.8837941 & 0.1162059 \\
\hline 12 & $2.32 \mathrm{E}-02$ & 0.9070352 & $9.30 \in-02$ \\
\hline 13 & $1.86 \mathrm{E}-02$ & 0.9256282 & $7.44 E-02$ \\
\hline 14 & 1.49E-02 & 0.9405025 & $5.95 E \cdot 02$ \\
\hline 15 & 1.19E-02 & 0.952402 & 0.047598 \\
\hline 16 & $9.52 \mathrm{E}-03$ & 0.9619216 & 3.81E-02 \\
\hline 17 & $7.62 \mathrm{E}-03$ & 0.9695373 & $3.05 E-02$ \\
\hline 18 & $6.09 \mathrm{E}-03$ & 0.9756298 & $2.44 E-02$ \\
\hline 19 & $4.87 E-03$ & 0.9605039 & $1.95 E-02$ \\
\hline 20 & $3.90 \mathrm{E}-03$ & 0.9844031 & 1.56E-02 \\
\hline 21 & $3.12 \mathrm{E}-03$ & 0.9875224 & $1.25 E-02$ \\
\hline 22 & $2.50 \mathrm{E}-03$ & 0.990018 & $9.98 \varepsilon-03$ \\
\hline 23 & $2.00 E-03$ & 0.9920143 & $7.99 \in-03$ \\
\hline 24 & 1.60E-03 & 0.9936115 & 6.39E.03 \\
\hline 25 & 1.28E-03 & 0,9948891 & $5,11 E-03$ \\
\hline 20 & $1.02 \mathrm{E}-03$ & 0.9959113 & 0.0040887 \\
\hline 27 & 8. $18 \mathrm{E}-04$ & 0.996729 & 3.27E-03 \\
\hline 28 & 6.54E-04 & 0.9973832 & $2.62 \mathrm{E} \cdot 03$ \\
\hline 29 & $5.23 \mathrm{E}-04$ & 0.9979065 & $209 E-03$ \\
\hline $3 d$ & $4.19 E-04$ & 0.9983252 & $1.67 \mathrm{E} \cdot 03$ \\
\hline
\end{tabular}

Jika dilihat pada kolom Prob (num in sys) =k, dapat diinterpretasikan; untuk probabilitas jumlah pelanggan minimal 3 sampai 4 pelanggan berada dalam sistem pelayanan yaitu sebesar 13,85\% , karena sebelum itu, pemasangan 5 kasir bank CIMB tidak efektif, seperti terlihat pada grafik (M/M/s). 


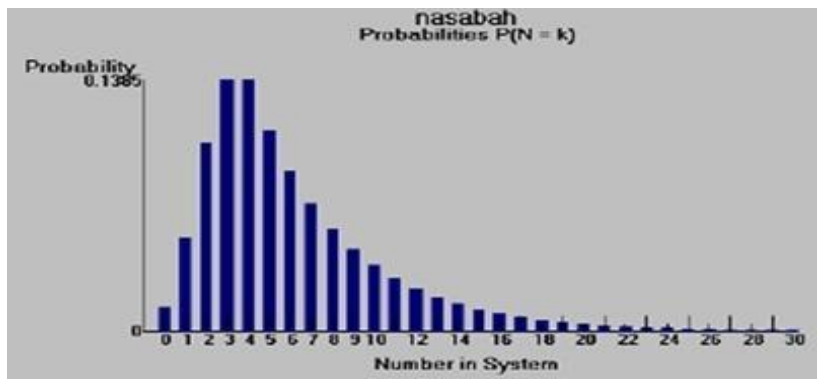

\section{F. Latihan soal}

Diketahui rata-rata kedatangan pelanggan setiap 4 menit (dalam waktu 4 menit ada satu langganan yang datang), rata-rata waktu pelayanan 2,5 menit (untuk melayani seorang pelanggan diperlukan waktu 2,5 menit). Hitunglah:

a. Rata-rata banyaknya para pelanggan dalam system

b. Rata-rata waktu seseorang pelanggan menunggu dalam antrian

c. Rata-rata waktu seseorang pelanggan yang menunggu sebelum menerima layanan 